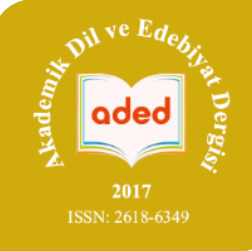

Mehmet ÖZDEMİR

Doç. Dr., Bilecik Şeyh Edebali

Üniversitesi

mehmet.ozdemir@bilecik.edu.tr

\section{iD}

https://orcid.org/0000-0003-0544-9280

\section{Akademik Dil ve Edebiyat Dergisi} Academic Journal of Language and Literature CIILT/VOLUME: 4, SAYI/ISSUE: 1, NISAN/APRIL 2020

\title{
Seyyid Nesîmî'nin Neşredilmemiş Tuyuğları
}

\author{
Unpublished Tuyugs of Seyyid Nesimi
}

\author{
Araştırma Makalesi/Research Article \\ Geliş Tarihi/Received: 21.07.2020 \\ Kabul Tarihi/Accepted: 24.08.2020 \\ Yayım Tarihi/Published: 30.08.2020
}

\section{Atıf/Citation}

Özdemir, Mehmet (2020). Seyyid Nesîmî'nin NeşredilmemişTuyuğları. Akademik Dil ve Edebiyat Degisi, C. 4 (2), s. 403-485. DOI: 10.34083/akaded. 772733

Özdemir, Mehmet (2020). Unpublished Seyyid Nesimi's Thuyugs. Journal of Academic Language and Literature, C. 4 (2), s. 403-485. DOI: 10.34083/akaded.772733

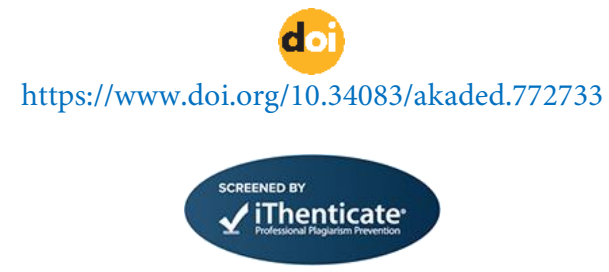

Bu makale iThenticate programıyla taranmıştır.

This article was checked by iThenticate. 


\section{$\ddot{O} z$}

Türk şiirinin lirik söyleyişlerine farklı nazım şekilleriyle ses veren Seyyid Nesîmî tuyuğ nazım şekliyle en çok şiir yazan şairdir. Nesîmî'nin tuyuğları Türkiye'de ve yurt dışında neşri yapılan Nesîmî Dîvânı çalışmaları başta olmak üzere bazı araştırmacıların makalelerine de konu olmuştur. Bu çerçevede Türkiye'de ve Azerbaycan'da neşredilen Nesîmî Dîvânı çalışmalarında yer almayan Nesîmî tuyuğları konusunda iki adet makale yazılmıştır. Türkiye'de bulunan yazma eser kütüphanelerinde kayıtlı mecmualarda yer alan bu tuyuğların neşri ile bilinen Nesîmî tuyuğlarına yenileri eklenmiştir.

Nesîmî Dîvânı'nın bilinmeyen nüshaları ya da Nesîmî şiirlerinin yer aldığg mecmualar keşfedildikçe Türk şairler içinde en çok tuyuğ yazan şair olma unvanına sahip olan Nesîmî'nin henüz neşri yapılmamış şiirlerine rastlamak mümkündür. Çalışmada, Nesîmî'nin İstanbul Araştırmaları Enstitüsü Kütüphanesi yazmalar koleksiyonu Şevket Rado Yazmaları SR_000002 numarada kayıtlı el yazması Nesîmî Dîvânı'nında yer alan ve bugüne kadar neşri yapılmamış tuyuğların ilim dünyasına tanıtılması hedeflenmiştir. Bu çerçevede Nesîmî'nin neşredilmemiş 225 tuyuğunun tam metinleri Latin harfleriyle ve transkripsiyonlu metin halinde araştırmacıların dikkatine sunulmuştur.

Anahtar Sözcükler: 14. Yüyzıl Türk Şiiri, Seyyid Nesîmî, Nesîmî Dîvânı, Tuyuğ.

\section{Abstract}

Seyyid Nesimî, who gave voice to lyric sayings of Turkish poetry through diverse verse forms, was the most prolific tuyug verse poet. Tuyugs of Nesîmî was the subject of many articles, particularly Nesîmî Dîvânı, which distributed in Turkey and abroad. In this context, two articles published on Nesîmî tuyugs which was not included in Nesîmî Dîvânı, distributed in Turkey and Azerbaijan. New additions were made to Nesimî tuyugs by distribution of these tuyuğs, which were found in journals registered in manuscript work libraries in Turkey.

The encounter of unpublished works of Nesimî, who was the most prolific tuyug poet among Turkish poets, could be possible with the discovery of unknown copies of Nesimî Dîvânı or journals published Nesimî poetry. In this work, the introduction of Nesimî tuyugs which are found in SR_000002 numbered Şevket Rado manuscripts in Istanbul Research Institute Library, Manuscript collection, is aimed. In this context, 225 unpublished tuyugs of Nesimî are reported in form of Latin letters and transcripted text.

Keywords: $14^{\text {th }}$ century Turkish Poetry, Seyyid Nesîmî, Nesîmî's Diwan, Tuyugs. 


\section{Giriş}

Tuyuğ kelimesi Türk dilinin çeşitli lehçelerinde tuyuğ, tuyuk, duyug, toyık, toyuk şekillerinde bulunmaktadır. Kelime kapalı, imalı, gizli, cinaslı söz söyleme, şarkı söyleme, şiir, şarkı, türkü anlamlarına gelir. Edebi terim olarak ise dört mısradan oluşan, genellikle aruzun fâilâtün fâilâtün fâilün kalıbıyla ve rubai kalıpları dışında 11'li hece ölçüsüne denk düşen kalıplarla yazılan, bir düşünce, hikmet ya da mühim fikirlerin anlatılması için tercih edilen nazım şeklidir. Tuyuğun millî bir nazım şekli olduğu ve mani nazım şeklinin etkisiyle daha çok aaxa kafiye şeması ile yazıldı̆̆ı genel kabul gören görüştür. Bunun yanında bütün mısraları aaaa düzeninde kafiyeli, nadiren kıta nazım şeklinde olduğu gibi xaxa kafiye şemasıyla yazılan tuyuğlara da rastlamak mümkündür (İlaydın 1964: 112; İpekten 1994: 70; Cengiz 1986: 421-427; Öztoprak 2012: 450; Saraç 2007: 99).

Tuyuğun dörtlüklerden oluşan bir nazım şekli olmadığını, iki beyitlik bir gazel çeşidi olduğunu savunan ve tıpkı şarkı gibi gerçekte bir nazım şekli değil fâilâtün fâilâtün fâilün vezninde yazılarak bestelenmiş ya da bestelenmek maksadıyla yazılmış iki beyitlik gazel çeşidi kabul eden görüşler de vardır (Kurnaz-Çeltik 2013: 146-154).

Tuyuğ nazım şeklinin sadece fâilâtün fâilâtün fâilün vezniyle yazıldığını iddia eden araştırmacılar olsa da yakın zamanlarda yapılan bir çalışmada mefâîlin mefâîlin fê̂lün, feilâtün mefâilün feilün kalıplarıyla yazılan tuyuğların olduğu görülmüştür. Türk edebiyatında yazılmış bütün tuyuğ metinlerini bir arada ortaya koymayı hedefleyen Mehmet Sait Çalka, çalışmasında tespit ettiği 1547 tuyuğdan 107'sinin mefâîlin mefâilin feûlün vezninde, 12'sinin ise feilâtün mefâilün feilün vezninde yazıldığını bildirmektedir (Çalka 2019: 20-21).

Tuyuğ nazım şeklinin menşeini Oğuz Türklerine dayandıran M. Fuad Köprülü, tuyuğun Türk ve İran edebiyatındaki çeşitli unsurların imtizacıyla teşekkül ettiği ve millî bir nazım hüviyetine büründüğü görüşündedir. M. Fuad Köprülü, tuyuğun başlangıçta dört mısralı ve imalı bir türkü iken İran rubailerinin etkisiyle değişime uğrayıp 11'li hece ölçüsüne denk düşen fâilâtün fâilâtün fâilün veznine evrildiğini, daha sonra imaların da kalkarak cinaslara dönüştüğünü ve şekil ve vezin yönüyle Fars rubailerine benzer bir şekil aldığını ifade eder (Köprülü 1989: 202-208).

İlk örneklerini 14. yüzyılda Alî, Kadı Burhanedddin, Nesîmî ile gördügüümüz tuyuğ nazım şekli Türk edebiyatındaki varlığını 20. yüzyıla değin sürdürmüştür. Kadı Burhaneddin, Mevlânâ Lutfî, Dede Ömer Ruşenî ve Misâlî yüzden fazla tuyuğ yazmış şairler arasında olsa da bu nazım şeklinin en çok örneğini veren şairin Nesîmî olduğu bilinmektedir (Çalka 2019: 76-79). 


\section{Seyyid Nesîmî'nin Neşredilmiş Tuyuğları}

\section{a) Divan Neșirlerinde Yer Alan Tuyuğlar}

Seyyid Nesîmî'nin Türkçe Dîvânı üzerine Türkiye, Azerbaycan ve İran'da yapılmış ilmî neşirler incelenerek bu eserlerde yer alan tuyuğlarla ilgili sayısal bilgiler aşağıda yer alan başlıklar altında özetlenmiştir ${ }^{1}$. Ayrıca Seyyid Nesîmî'nin Türkçe Dîvânı'nın çalışmamıza konu olan Şevket Rado $^{2}$ nüshasında yer alan tuyuğların bu çalışmalarda kaç adedinin bulunduğu da belirtilmiştir.

\section{a.1. Ayan, Hüseyin (2014). Nesîmî Hayatı, Edebî Kişiliği, Eserleri ve Divanının Tenkitli Metni [Birleştirilmiş Baskı], Ankara: TDK Yay.}

Nesîmî Dîvânı üzerine Hüseyin Ayan tarafından hazırlanan doktora tezi 1970 yılında tamamlanmıştır ${ }^{3}$. Tez çalışmasında, çoğunluğu Türkiye'de birkaçı da yurt dışındaki bazı kütüphanelerde bulunan, erişebildiği Nesîmî Dîvânı nüshalarından hareketle divanın transkripsiyonlu ve tenkitli metnini hazırlamıştır. Hüseyin Ayan'ın doktora tezi olarak hazırladığı Nesîmî Dîvânı 1990, 2002 ve 2014 yıllarında basılmıştır. Bu çalışmada yer alan tuyuğ sayısı 315 olup bu tuyuğlardan 283'ü ŞR nüshasında bulunmaktır.

a.2. Qəhrəmanov, Cihangir (1973). İmâdüddîn Nesîmî, Eserleri. 3 C, Bakı: Azerbaycan SSR İlimler Akademiyası Respublika El Yazmalar Fondu "İlim" Neşriyatı. Redaktör: Hamid Araslı.

Nesîmî Dîvânı'nın ilmî neşri konusunda Azerbaycan'da yapılmış çalı̧̧malardan en önemlisi Cihangir Qəhrəmanov tarafından hazırlanan neşirdir. 1973'te basılan bu çalışmanın inceleme kısmı Kiril alfabesi, divan metni ise Arap harfleriyle ve tenkitli metin olarak hazırlanmıştır. Üç ciltten oluşan bu çalışma Nesîmî'nin ikisi Azerbaycan, birer adedi de Leningrad/Rusya, Ermenistan ve Özbekistan'da bulunan beş el yazması ve iki matbu divan nüshasından istifade edilerek hazırlanmıştır.

Nesîmî Dîvânı neşirleri içinde en çok tuyuğ ihtiva edeni Cihangir Qəhrəmanov tarafından yapılan çalışmadır. Çalışmanın II. cildinde 234 tuyuğ $\breve{g}^{4}$ bulunmaktadır. Bu ciltte "İlaveler" başlı̆̆ı altında Cihangir Qəhrəmanov'un Nesîmî'ye aidiyeti konusunda

\footnotetext{
${ }^{1}$ Seyyin Nesîmî'nin Türkçe Dîvânı'nın bahse konu neşirleri ve neşredilmemişs şïleri ile ilgili ayrıntılı değerlendirme için bakınız: Özdemir, Mehmet (2020). Seyyid Nesîmî Dîvânı'nın Kayda Değer Bir Nüshası ve Şairin Neşredilememiş Türkçe Şiirleri. Divan Edebiyatı Araștırmaları Dergisi, Sayı, 24, s. 3-13.

2 Yazının buradan sonraki aşamalarında Şevket Rado nüshası için "ŞR" kısaltması kullanılmıştır.

${ }^{3}$ Ayan, Hüseyin (1970). Nesîmî, Hayatı, Edebî Kişiliği, Eserleri ve Türkçe Divanınn Metni. Doktora Tezi, Erzurum: Atatürk Üniversitesi.

${ }^{4}$ Qəhrəmanov neşrinde tuyuğlar "Rubâiler" bașlığı altında verilmiștir.
} 
şüpheye düştügü çeşitli nazım şekillerinde yazılmış 128 şiir yer almaktadır. $\mathrm{Bu}$ şiirlerden 15 tanesi tuyuğ nazım şekliyle yazılmıştır. İkinci cildin 614 - 615 sayfalarında yer alan ve dörder dizeden oluşan dört şiirin ikisi kıt'a, biri de nazmdır. Fürkatde meni ey meh-i tābānum unutma ${ }^{5}$ mısaı ile başlayan şiir ise rubâîdir. Dolayısıyla II. ciltte yer alan tuyuğ sayısı toplamda 249 adettir.

III. ciltte ise 115 tuyuğ yer almaktadır. Cihangir Qəhrəmanov neşrinin birinci ve ikinci cildinde yer alan toplam tuyuğ sayısı $364^{\prime}$ tür. Ancak bu çalışmada mükerrer yazılmış 16 tuyuğ bulunmaktadır. Mükerrer yazılan bu tuyuğlar çıkarıldığında çalışmada yer alan toplam tuyuğ sayısı 348 olarak değişecektir. Cihangir Qəhrəmanov neşrinin iki cildinde yer alan toplam 348 tuyuğdan 275'i ŞR nüshasinda vardır.

Cihangir Qəhrəmanov neşrinin hem II. cildinde hem de III. cildinde yer alan 16 mükerrer tuyuğun ilk mısraları aşağıdaki tabloda yazılarak bu tuyuğların hangi ciltlerde ve sayfalarda yer aldıkları karşılarında gösterilmiştir:

\begin{tabular}{|c|c|}
\hline Mükerrer Tuyuğların İlk Mısraları & Cilt ve Sayfa Numarası \\
\hline 1. Ey saçuñ $v e^{\prime} l-l e y l$ ü yüzüñ $v e^{\prime} d-d \underline{u} u \bar{a}$ & Qəhrəmanov, C. II, s. 606; C. III, s. 161. \\
\hline 2. Ey yüzüñ ve'l-fecr yüzüñdür niḳāb & Qəhrəmanov, C. II, s. 607; C. III, s. 162. \\
\hline 3. Çün zamāne geldi geçdi yoḳ medār & Qəhrəmanov, C. II, s. 609; C. III, s. 163. \\
\hline 4. Ey gönül Haḳ sendedür Haḳ sendedür & Qəhrəmanov, C. II, s. 379; C. III, s. 163. \\
\hline 5. Ṣāf içen dā’im șafā hạạsıl ḳılur & Qəhrəmanov, C. II, s. 609; C. III, s. 171. \\
\hline 6. Fā vü żād u lāma düşdi göñlümüz & Qəhrəmanov, C. II, s. 400; C. III, s. 171. \\
\hline 7. Bir 'acāyib şāha düşdi göñlümüz & Qəhrəmanov, C. II, s. 397; C. III, s. 172. \\
\hline 8. 'Āşıḳuñ adı neden abdāl imiş & Qəhrəmanov, C. II, s. 610; C. III, s. 174. \\
\hline 9. Çünki Selmān og̉lı üstād er imiş & Qəhrəmanov, C. II, s. 611; C. III, s. 175. \\
\hline 10. Haḳk'a doğrı baḳ vü Haḳk’ı doġrı bil & Qəhrəmanov, C. II, s. 611; C. III, s. 182. \\
\hline 11. Vechüñe cebbār-1 'ālemden selām & Qəhrəmanov, C. II, s. 612; C. III, s. 185. \\
\hline 12. Bunca hāy hū vü bunca hāy u hū & Qəhrəmanov, C. II, s. 459; C. III, s. 192. \\
\hline 13. Ey lebüñ vașlı hayāt-ı sermedi & Qəhrəmanov, C. II, s. 613; C. III, s. 197. \\
\hline 14. Göñlümüz bir yār elinden hastedür & Qəhrəmanov, C. II, s. 608; C. III, s. 168. \\
\hline 15. Yidi kez otuz iki durur yüzüñ & Qəhrəmanov, C. II, s. 425; C. III, s. 179. \\
\hline 16. 'Aşḳ içinde gör ne hạayrān olmuşam & Qəhrəmanov, C. II, s. 612; C. III, s. 184. \\
\hline
\end{tabular}

${ }^{5}$ Qəhrəmanov, C. II, s. 614. 


\section{a.3. Araslı, Hamid (hzl.) (2004). İmâdüddin Nesîmî, Seçilmiş Eserleri, 2 Cilt, Bakı. Lider Neşriyat.}

Hamid Araslı tarafından 2 cilt halinde Bakü'de ilk defa 1973'te yayımlanmış, daha sonra 2004'te yeniden ikinci kez basılmıştır. Araslı'nın 2 cilt olarak neşrettiği çalışmasında çeşitli nazım şekillerinde yazılmış Nesîmî'ye ait 800 şiir yer almaktadır. Araslı neşrinde biri mükerrer 327 tuyuğ bulunmaktadır. Mükerrer tuyuğ hariç mevcut 326 tuyuğdan 257'si ŞR nüshasında vardır ${ }^{6}$.

\section{a.4. Sədiq (Düzgün), Hüseyn Məhəmmədzadə (2008). Seyyid İmadəddin Nosimi, Türkçe Divanı. Təbriz şəhəri: Oxtər Nəşriyyatı.}

Nesîmî'nin Türkçe Dîvân'ı neşirlerinden biri de Prof. Dr. Hüseyn Məhəmmədzadə Sədiq (Düzgün) tarafından 2008 'de İran'da yapılan neşirdir. Bu çalışmada Sədiq, Azerbaycan ve Türkiye'de daha önce yapılan neşir çalışmalarını merkeze alarak ve bu çalışmalardan faydalanarak Nesîmî'nin Türkçe Dîvânı'nı Arap harfleriyle yeniden neşretmiştir. Çalışmada toplam 279 tuyuğ yer almaktadır ve bu tuyuğlardan 228'i ŞR nüshasında vardır.

Hüseyn Məhəmmədzadə Sədiq'in hazırladığı çalışmada yer alan 279 tuyuğdan biri mükerrerdir7. Geriye kalan 278 tuyuğdan 220'si ŞR yazmasında vardır.

\section{b) Divan Neșirleri Dışındaki Çalışmalarda Yer Alan Tuyuğlar}

Seyyid Nesîmî'nin Türkçe Dîvânı'nın yukarıda bahsi geçen neşirleri yanında yurt içi ve yurt dışındaki çeşitli kütüphanelerde kayıtlı yazma mecmualarda yer alan Nesîmî şiirleri de araştırmacılar tarafından tespit edilerek neşredilmiştir. Aşağıda görüleceği üzere bu çalışmaların ikisi münhasıran neşredilmemiş Nesîmî tuyuğlarını konu almaktadır. Seyyid Nesîmı̂'nin tuyuğlarının bir kısmını ihtiva eden bu çalışmaların muhtevaları hakkında özet bilgiler aşağıda verilmiştir.

\section{b.1. Çalka, Mehmet Sait (2019). Klasik Türk Şiirinde Tuyuğ, İstanbul: Kriter Yayınevi.}

Mehmet Sait Çalka, 14. yüzyıldan 19. yüzyıla kadar geçen zaman aralığında divan tertip etmiş yaklaşık 900 şairin neşredilmiş divanlarını ve Nesîmî şiirlerini konu alan makaleleri inceyelerek tespit ettiği 1547 tuyuğun neşrini yapmıştır. Tuyuğun nazım

\footnotetext{
${ }^{6}$ Sadece ilk dizedeki kısmî farkla mükerrer yazılan ve diğer mısraları aynı olan tuyuğun ilk mısraı: Haḳ Teāalā perdesüz oldı 'ayān: Ḥaḳ götürdi perdeyi oldı 'ayan; Araslı, s. 294-295.

${ }^{7}$ Araslı mükerrer yazlan tuyuğ -sadece sıra değişikliği ile- aynı şekilde Sədiq neşrinde de mükerrer yazılmıştır: Ḥaḳ götürdi perdeyi oldı 'ayan: Haḳ Te ālā perdesüz oldı 'ayān; Sədiq, s. 459.
} 
şekli olarak incelenmesi ve tarihsel gelişimi üzerinde ayrıntılı incelemeler yapan yazar tuyuğ yazdığını tespit ettiği 67 şarinin tuyuğ metinlerini çalışmasına almıştır.

Yazar, Hüseyin Ayan neşrinde yer alan 315 tuyuğa M. Fatih Köksal ve Ömer Zülfe'nin çalışmalarında yer alan 22 tuyuğu da ilave ederek Nesîmî'nin 337 tuyuğunu çalışmasına dâhil etmiştir. Ancak bu çalı̧mada -yukarıda adları ve içeriklerine yer verilen- Azerbaycan'da ve İran'da yayımlanmış Nesîmî Dîvânı neşirleri ile M. Fatih Köksal'ın münhasıran Nesîmî'nin tuyuğlarını konu alan çalışmasına müracaat edilmemiştir. Bu sebeple çalışmada yer alan Nesîmî tuyuğları şairin bütün tuyuğlarını ihtiva etmemektedir.

b.2. Köksal, M. Fatih (2000). Seyyid Nesîmî'nin Bilinmeyen Tuyuğları. Journal of Turkish Studies, Agâh Sırrı Levend Hatıra Sayısı II, V. 24, Harvard University Pres, s.138-208.

Makalede, Şemseddin Sivâsî'nin Menâzilü'l-Ârifîn adlı eserinden ve Nesîmî'nin tuyuğlarından oluşan bir yazma eser tanıtılmış ve bu yazma içerisinde yer alan ancak Türkiye'de basılmış Nesîmî Dîvânı neşirlerinde bulunmayan 33 tuyuğ transkripsiyonlu metin olarak neşredilmiştir. Makalede yer alan tuyuğlardan 4'ü 1973 yılında hazırlanmış olan Qəhrəmanov neşrinde vardır. M. Fatih Köksal'ın makalesinde yer alan 33 tuyuğdan $30^{\prime}$ u ŞR nüshasında bulunmaktadır.

\section{b.3. Zülfe, Ömer (2005). Seyyid Nesîmî'nin Tuyuğlarına Ek. Modern Türklük Araştırmaları Dergisi, 2 (4) s. 121-135.}

Yazar, Nuruosmaniye Kütüphanesi 4962 numarada kayitlı Mecmû'a-i Müntehabât-ı Kasâ'id ve Eş'âr adlı yazma mecmuada yer alan ve insan uzuvlarının anlatıldığı 31 adet tuyuğu neşretmiştir. Yazıda alın, kaş, göz, yanak, ben, yüz, dudak, ağız, diş, dil, çene, burun, gögüs, boy, parmak, ayak, gönül, söz başlıkları altında ilgili vücut organları ve diğer unsurlarla ilgili tuyuğlar yazılmıştır. Ömer Zülfe'nin makalesinde yer alan 31 tuyuğdan 29'u ŞR nüshasında bulunmaktadır.

\section{b.4. Köksal, M. Fatih (2009). Seyyid Nesîmî'nin Yayımlanmamış Şiirleri, Türk Kültürü ve Hacı Bektaş Velî Araştırma Dergisi, Sayı: 50, s. 77-135.}

Bu makalede yazar şahsî kütüphanesinde mevcut beş mecmua ve iki cönkte yer alan ancak daha önce Türkiye'de yayımlanmış Nesîmî Dîvânı neşirlerinde bulunmayan 26 şiir ile Türkiye'de ve Azerbaycan'da yayımlanan Nesîmî divanlarının hiçbirinde yer almayan 19 Türkçe şiiri neşretmiştir. M. Fatih Köksal, makalesinde 1 kaside, 42 gazel ve 2 tuyuğdan oluşan toplam 45 şiiri nüsha karşılaştırması yaparak transkripsiyonlu metin halinde araştırmacıların istifadesine sunmuştur. Makalede neşri yapılan 2 tuyuğ da ŞR nüshasında bulunmamaktadır. 
b.5. Özdemir, Mehmet (2020). Seyyid Nesîmî Dîvânı'nın Kayda Değer Bir Nüshası ve Şairin Neşredilmemiş Türkçe Şiirleri", Divan Edebiyatı Araştırmaları Dergisi, Sayı, 24, s. 439-504.

Mehmet Özdemir makalesinde Oxford Üniversitesi Bodleian Kütüphanesinde kayıtlı bir nüshasını tanıtarak daha önce yapılan Nesîmî Dîvânı ya da şiirlerinin neşirlerinde başvurulmayan bu nüshanın muhtevası hakkında bilgi vermiştir. Bu çerçevede nüshada yer alan her bir şiirin ilk mısralarından oluşan ve yapılan neşirlerde yer alanların bulundukları kaynakları da göstererek bir liste oluşturmuştur. Daha önce neşri yapılmamış 2 gazel ve 2 tuyuğun ise tam metnini vermiştir. Bu 2 tuyuğdan biri ŞR nüshasında bulunmaktadır.

\section{Nesîmî Tuyuğlarının Neşirlerdeki Sayısı}

Yukarıda adları ve ihtiva ettiği tuyuğ sayıları yer alan çalışmaların tabloya aktarılarak bir araya getirilmiş hali aşağıda gösterilmiştir. Tabloda yer alan tuyuğ sayıları her müstakil çalışmanın ortaya koyduğu sayıyı göstermektedir. Nesîmî tuyuğlarının nihai sayısı yapılan bütün bu çalışmalardan hareketle neşri yapılan tuyuğların mukayesesini yapan başka bir çalışma ile mümkün olacaktır. Zira "neşredilmemiş tuyuğlar" ifadesiyle yapılmış çalışmalarda yer alan bazı tuyuğların neşrinin ilk kez bahsi geçen çalışmalarla yapılmadığı ya da Nesîmî Dîvânı neşirlerinde aynı ciltte bile mükerrer yazımların olduğu görülmektedir (Özdemir 2020: 441-450).

Nesîmî'nin bugüne kadar neşredilmiş çalışmalarda yer alan tuyuğlarının sayısı, ŞR nüshasında yer alan tuyuğların bu neşirlerdeki sayıları ve ŞR olmayan ancak neşirlerde yer alan tuyuğların sayıları aşağıda yer alan tablolarda gösterilmiştir.

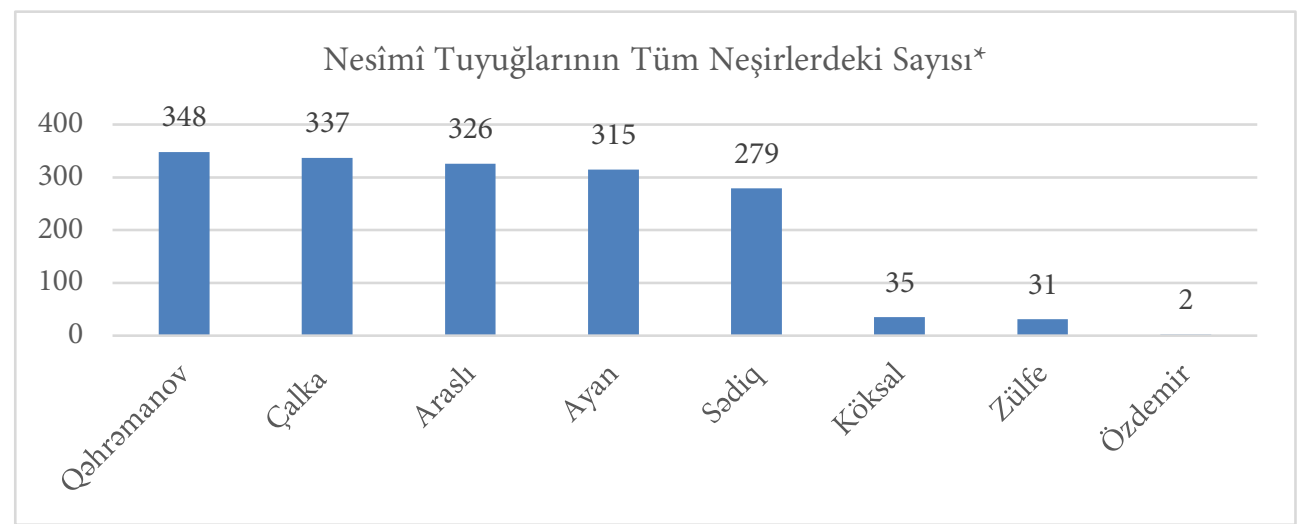

*Tabloda M. Fatih Köksal tarafından yapılan iki çalışmada yer alan toplam tuyuğ sayısı verilmiştir. 


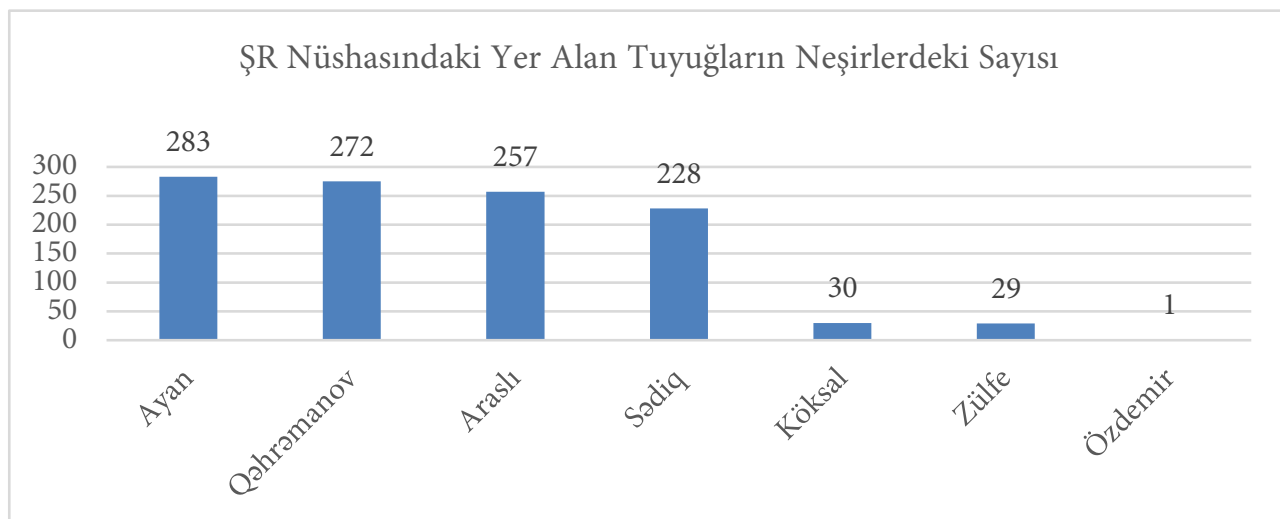

*Tabloda M. Fatih Köksal tarafından yapılan iki çalışmada yer alan toplam tuyuğ sayısı verilmiştir.

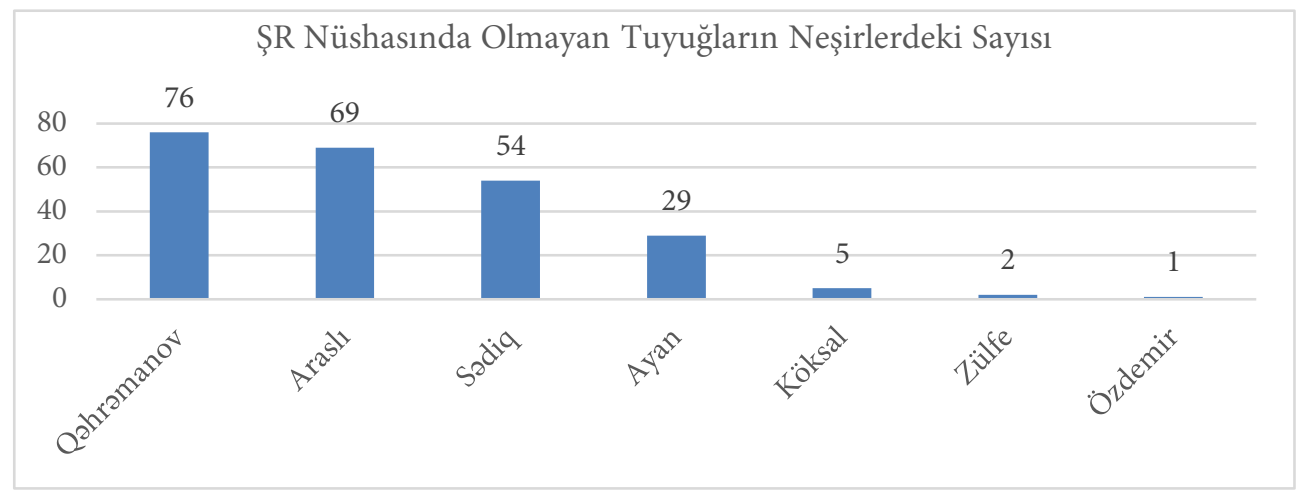

\section{Nesîmî Dîvânı'nın Şevket Rado Nüshası}

İstanbul Araştırmaları Enstitüsü Kütüphanesi Yazmalar koleksiyonu Şevket Rado Yazmaları SR_000002 numarada yer alan el yazması Nesîmî Dîvânı'nın katolog bilgilieri aşağıda yazıldığı gibidir:

Konu Başlıkları: Türk Şiiri, Divan Şiiri.

Dizi Kaydı: Şevket Rado Yazmaları.

Fiziksel Nitelik: 255x165, 180x105 mm. 292 yk., 2 stn., 21 st., nesih.

Başlıklar ve bazı kelimelerin yazımı kırmızı mürekkepledir. Açık krem, sarı, pembe, ince, aharlı ortasında "BATH" yazan kenarları yaprak süslemeli soğuk damgalı kağıt kullanılmıştır. Eser reddadelidir. Mukavva üzerine sırtı ve kenarları kahverengi

\footnotetext{
${ }^{8}$ Bkz: İstanbul Araştırmaları Enstitüsü Yazma Eserler Kataloğu. C. 2, s. 596.
} 
deri, miklepli kendinden desenli kağıt ciltlidir. Başta ve sonda yeşil koruyucu yapraklıdır. Nüsha üzerindeki düzeltme ve notlardan nüshanın mukabele gördüğü düşünülebilir. 1a'da nüshanın içinde kaçar adet gazel, teci-bent, mesnevi, kıta ve rubai bulunduğu yazılır. Ayrı bir kağıtta Şevket Rado, Hayat Mecmuası'nda M. Fuat Köprülü'nün "Nesîmî'ye Dair" adlı makalesinde Nesîmî'nin ölüm tarihinin 807/104 olduğunu belirttiğini not etmiştir.

Notlar: $242^{\mathrm{b}}, 243^{\mathrm{a}}-244^{\mathrm{b}}, 245^{\mathrm{a}}-246^{\mathrm{a}}, 248^{\mathrm{b}}-250^{\mathrm{a}}, 253^{\mathrm{b}}, 260^{\mathrm{b}}-261^{\mathrm{a}}, 268^{\mathrm{a}}, 269^{\mathrm{b}}, 271^{\mathrm{a}}$, $273^{\mathrm{b}}-274^{\mathrm{b}}, 279^{\mathrm{a}-\mathrm{b}}, 280^{\mathrm{b}}, 283^{\mathrm{b}}-284^{\mathrm{b}}, 290^{\mathrm{a}}-291^{\mathrm{b}}, \mathrm{I}^{\mathrm{a}}-\mathrm{XI}^{\mathrm{b}}$ boş.

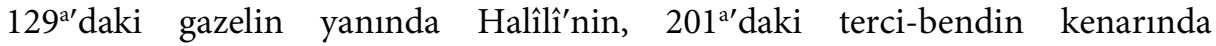
Ahmedî'nin olduğu yazılıdır.

Başı:

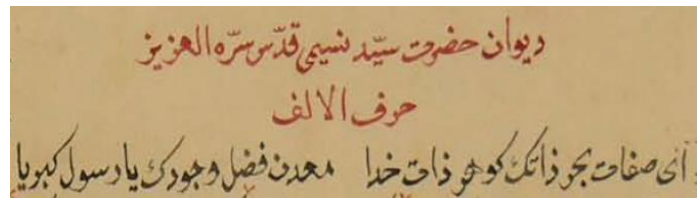

Sonu:

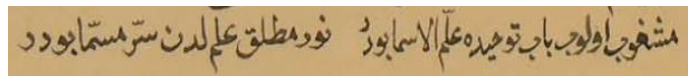

Nüshada yaklaşık 720 gazel, 8 müstezat, 6 terci-bent, 3 mesnevi, 3 kıta, 628 rubai bulunmaktadır. Birçok şiirde düzetlmeler ve derkenar notları vardır. $129^{a^{\prime}}$ daki gazelin yanında Halîlî'ye ait olduğu, 201 ${ }^{a}$ daki terci-bendin kenarında ise Ahmedî'nin olduğu yazilıdır?.

Katalog kayıtlarında yer alan yukarıdaki bilgiler dışında Nesîmî Dîvânı'nın ŞR nüshasının şekil ve muhtevasıyla ilgili daha ayrıntılı bilgilere yer verilmesi nüsha tanıtımı açısından uygun olacaktır.

İstanbul Araştırmaları Enstitüsü Şevket Rado Yazmaları Nu. 000002'de kayıtlı Dîvân-ı Nesîmî, 303 varaktan oluşmaktadır. Tuyuğların yer aldığ $1203^{\mathrm{b}}-241^{\mathrm{a}}$ varakları ise başlıklar hariç 14 satıra yazılmıştır. Nüshanın istinsah tarihi ve müstensihi belli değildir. Yazmaya rakamlarla 1'den başlayarak 303'e kadar varak numarası verilmiştir. Yazmada Nesîmî'nin mahlası, şiir başlıkları ve bazı tashih metinleri kırmızı mürekkeple yazılmıştır.

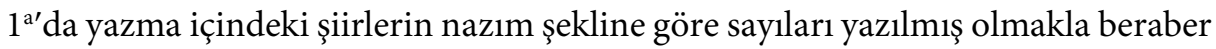
bu, şiir sayısını doğru şekilde yansıtmamaktadar. Burada nazım şekline göre tasnif edilmiş şiir sayısı 1340 iken yazmadaki şiirlerin sayısı aslında 1437'dir. ŞR nüshası, ihtiva ettiği 1437 şiir ile Nesîmî Dîvânı nüshalarının en hacimlisidir. En önemli özelliği,

\footnotetext{
${ }^{9}$ Katalogta verilen yukarıdaki sayılara göre ŞR nüshasındaki toplam şiir sayısı 1368'dir. Yazmanın başında nazım şekline göre yazılan şiir sayısına göre toplam sayı 1340'tır. Bizim tespitimize göre ise nüshadaki toplam şiir sayısı 1437 'dir.
} 
diğer yazma nüshalarda ve dolayısıyla mevcut neşirlerde bulunmayan 225 tuyuğ ve çeşitli nazım türündeki kaleme alınmış şiirleridir ${ }^{10}$. Yazmadaki şiirler "Dîvān-1 Hażret-i Seyyid Nesîmî kuddise sırruhu" başlığından hemen sonra başlamaktadır.

$293^{a \prime}$ dan başlayarak $303^{a \prime}$ ya kadar olan sayfalar boştur. Yazmanın boş sayfaları bunlarla da sinırlı değildir. Katalog bilgilerinde de belirtildiği gibi $242^{\mathrm{b}}, 243^{\mathrm{a}}-244^{\mathrm{b}}, 245^{\mathrm{a}}-$ $246^{\mathrm{a}}, 248^{\mathrm{b}}-250^{\mathrm{a}}, 253^{\mathrm{b}}, 260^{\mathrm{b}}-261^{\mathrm{a}}, 268^{\mathrm{a}}, 269^{\mathrm{b}}, 271^{\mathrm{a}}, 273^{\mathrm{b}}-274^{\mathrm{b}}, 279^{\mathrm{a}}-^{\mathrm{b}}, 280^{\mathrm{b}}, 283^{\mathrm{b}}-284^{\mathrm{b}}$, $290^{\mathrm{a}}-291^{\mathrm{b}}$ sayfaları da boştur.

Nüshada yer alan şiirler üzerinde yer yer düzeltmeler yapılmıştır. Yapılan düzeltmelerden nüshanın mukabele edildiği ve tashih gördüğü anlaşılmaktadır. Şiirler üzerinde yapılan bu tür düzeltmeler yanında nüshada derkenar notları da vardır. $\mathrm{Bu}$ notlar şunlardır:

$2^{a}$ da "Elf-i a lā sidre boyuñ müntehādur müntehā" mısraı ile başlayan gazelin başına "bu gazel tertîb-i hurūf-1 ebced üzre yazıla" notu yazılmıştır.

$30^{\text {b’ }}$ de "Ug̉radı fürḳat oḳı uş cigerüm yana durur" mısraı ile başlayan gazelin başına "bu gazazel aşaġıda yazılıdur" notu yazılmıştır.

$105^{a \prime}$ da "Gitdi fürḳat irişdi 'ayn-1 vișāl" mısraı ile başyalan müstezadın başına "bu gazel terci-bendde yazılıdur, aşağıda gelür" notu yazılmıştır.

$128^{a}$ da "Aşḳuño derdime devā gördüm" mısraı ile başyalan gazelin başına "bu gazel tercì-bendde yazılıdur" notu yazılmıştır.

$129^{a}$ da "Men ki dervişem faḳirem pādişāh-1 'ālemem" mısraı ile başyalan gazelin başına "bu gazel Ḩalili'nüñ̃ür" notu yazılmıştır.

$199^{a}$ da "Gel 'ārif iseñ al ḩaberi ma'nā erinden" mısraı ile başyalan müstezadın başına "bu müstezād aşagìda yazıldur" notu yazılmıştır.

$219^{a}$ da "Her kimüñ ki çehresinde zerdi yoḳ" mısraı ile başyalan gazelin başına "yuḳarıda yazılmış" notu yazılmıştır.

$225^{a \prime}$ da " "Ālem-i faḳr-1 fenāda fāni ol" mısraı ile başyalan gazelin başına "yuḳarıda yazılmış" notu yazılmıştır.

$258^{a \prime}$ da "Ṣubḥ-dem çün nev-'arūs-1 çarh oldı āşikār" mısraı ile başyalan gazelin başına "bu gaazel Surūrì'nüñdür" notu yazılmıştır.

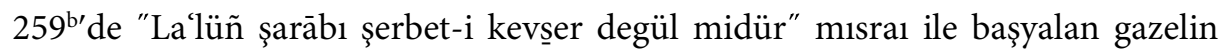
başına "bu gazel yuḳarıda yazılmışdur" notu yazılmıştır.

\footnotetext{
${ }^{10}$ ŞR nüshasında yer alan ve tuyuğlar dışındaki nazım şekilleriyle yazılan şiirler başka bir yazının konusu olarak yayıma hazırlanmış olup yayım sürecinde olduğundan daha ayrıntılı bilgilere gerek duyulmamıştır.
} 
ŞR nüshası şiirler üzerinde tashih çalışmaları yapılmış nüshadır. Yazmada yer alan şiirlerin pek çoğunda kelime değişikliği ya da metni tamire yönelik notlar kırmızı mürekkepli kalemle yazılmıştır. Bunun yanında yukarıda da bahsedildiği gibi nüshada Nesîmî mahlasıyla kayıtlı bazı şiirlerin başka şairlere ait olduğu notu yer almaktadır. Ancak 188a'da yer alan "Bunca yıllardur ser-i kūy-ı melāmet beklerüz/Leşker-i sulțān-ı "irfanuz velāyet beklerüz" matlalı gazelin ŞR nüshası dışında başka nüshalar ile yapılmış neşirlerde yer almadığı ve Fuzûlî'ye ait olduğu şüphe edilmeyecek bir durum olduğu halde şiirin makta beytinde mahlasın Nesîmî olarak yazılması tashih kaydını yapanların yetkinliğini nüshanın sıhhatini sorgulamamızı gerektirecek bir durumdur ${ }^{11}$.

Yazmada yer alan şiirler üzerinde kırmızı ya da siyah mürekkeple tashihler yapılmıştır. Bazı şiirlere ise başka şaire ait olduğuna dair notlar düşülmüştür. $\mathrm{Bu}$ durum nüshanın tümüyle tashih görmüş, sahh kayıtlı bir nüsha olduğunu göstermektedir. Nüshada musahhih ya da müstensihin kimliği ve yazmanın istinsah tarihine dair kayıt yoktur. Tuyuğların bittiği $241^{\text {a' }} \mathrm{da}$ "Temmet Divān-1 Hażret-i Seyyid Nesîmî kuddise sırruhu" ibaresi ve "aded-i varak 241" notu yer almaktadır. Ancak $241^{\text {b'de }}$ yazılan muhammesle devam eden çeşitli nazım şekillerinde yazılmış şiirler $292^{\text {b' }}$ de son bulmaktadır. $293^{\mathrm{a}}$ den $303^{\mathrm{b}}$ ye kadar olan varaklar boştur.

Yazmanın zahriyesinde Arap harfleriyle yazılan ve nüshadaki nazım şekillerini belirten not arka kapak iç sayfasında İngilizce olarak da yazılmıştır. Yine arka kapak iç sayfasında ayrı bir kağıtta Nesmîmî'nin ölüm tarihine dair Fuad Köprülü tarafından Hayat Mecmuası'nda yazılan H. 820 tarihinin doğru kabul edildiğini, ancak Nesîmî'nin ölüm tarihinin H. 807 tarihi olması gerektiği not edilmiştir. Ayrıca kütüphanenin matbu kataloğunda, eserin "bath" soğuk damgalı bir kâğıda yazılmış olduğu ifade edilmektedir. Bu bilgi ŞR nüshasının istinsah açısından muahhar bir nüsha olduğu düşündürmektedir.

\section{ŞR Nüshasında Rubâiyyât Başlı̆̆ı Altında Yer Alan Şiirler}

ŞR Nüshasında $203^{\mathrm{b}}-241^{\mathrm{a}}$ varakları arasında "rubâiyyât" başlı̆̆ altında yazılmış 597 manzume vardır. Rubâiyyât başlığ ile dört dizeden ya da iki beyitten oluşan nazım şekillerinin kastedildiği düşünülebilir. Zira bu başlık altında sadece tuyuğlar değil dört dizeden oluşan diğer nazım şekilleri de vardır. ŞR nüshasında "rubâiyyât" başlığı altında yer alan ve daha önce neşri yapılmış tuyuğ sayısı 359 'tır. Bu başlık altında yer alıp bugüne kadar neşredilmemiş 238 şiirin 225’i tuyuğ’dur.

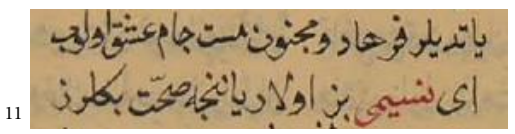




\section{a) ŞR Nüshasında Yer Alan Tuyuğlar Dışındaki Dört Dizelik Manzumeler}

Yazmada, tuyuğ nazım şekli dışında yer alan ve bugüne kadar neşredilmiş Nesîmî şiirleri arasında bulunmayan 13 manzume vardır. Bu manzumelerin tam metinleri aşağıdaki tabloda yer almaktadır. Manzumelerden ikisi dört dizeden müteşekkil hiçbir nazım şeklinin tüm özelliklerini taşımamaktadır. Kafiye düzeni rubâi, tuyuğ ve kıt'a nazım şekline uysa da vezni 4 tefileden oluşan bu manzumelerim ilk ikisi için Kurnaz ve Çeltik'in tanımlamasına uygun olarak iki beyitlik gazel denilebileceği kanaatindeyiz (Kurnaz-Çeltik 2013: 139-170). Tüm mısraları musarra olan 3, 4, 5, 6, 7 numaralı manzumelerin nazım şeklinin bilinen nazım şekli kriterlerinden hiçbirinin tüm özelliklerini taşımadığı görülmektedir. Söz konusu 5 manzumenin nazım şekli için ise en uygun tanımlamanın nazm olduğu düşüncesindeyiz.

\begin{tabular}{|c|c|c|c|}
\hline $\begin{array}{l}\text { Sira } \\
\text { No }\end{array}$ & $\begin{array}{c}\text { Varak } \\
\text { No }\end{array}$ & $\begin{array}{c}\text { Nazım } \\
\text { Şekli }\end{array}$ & Şiir Metni \\
\hline 01. & $225^{\mathrm{b}}$ & $\begin{array}{c}\text { İki } \\
\text { Beyitlik } \\
\text { Gazel }\end{array}$ & $\begin{array}{l}\text { Bu demi ḩoş gör ki yārā ol geçen dem dem degül } \\
\text { Bu demi añlamayanlar bellü bir ādem degül } \\
\text { Ādem u Havvā bu demde ḳadr-i vuṣlat buldılar } \\
\text { Şit ü Nūḥ oldı bu demde pes o dem [mātem]degül }{ }^{12}\end{array}$ \\
\hline 02. & $226^{a}$ & $\begin{array}{c}\text { İki } \\
\text { Beyitlik } \\
\text { Gazel }\end{array}$ & $\begin{array}{l}\text { Çün şeyāțīn gavàā ḳıldı ism-i a'zam yād ḳ̂l } \\
\text { Küntü kenzüñ perdesinden söylemek bünyād ḳıl } \\
\text { Len terānīnüñ cevābın Rabbi ernìden işit } \\
\text { Kul kefā billāhı țutğıl ḳaygudan āzād ḳıl }{ }^{13}\end{array}$ \\
\hline 03. & $232^{\mathrm{b}}$ & Nazm & $\begin{array}{l}\text { Fażl-ı feyyāż-ı ezelden lā-yezāli Şems-i dīn } \\
\text { Cān göginde țogalı bil kim Şems-i dīn } \\
\text { Göñüme yoldaş olalı çün hayāli Şems-i dīn } \\
\text { Sürdi cāndan gusșṣa-i gam hem melāli Şems-i dīn }{ }^{14}\end{array}$ \\
\hline 04. & $232^{\mathrm{b}}$ & Nazm & 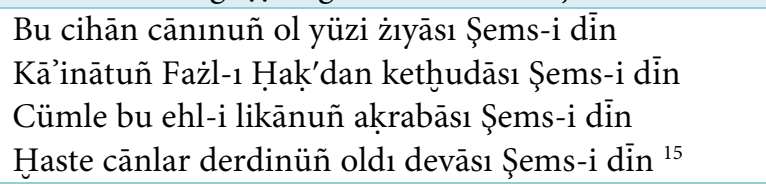 \\
\hline
\end{tabular}

\footnotetext{
${ }^{12}$ fâilâtün fâilâtün fâilâtün fâilün. 4. misrada vezin aksıyor.

${ }^{13}$ fâilâtün fâilâtün fâilâtün fâilün

14 fâilâtün fâilâtün fâilâtün fâilün

${ }^{15}$ fâilâtün fâilâtün fâilâtün fâilün
} 


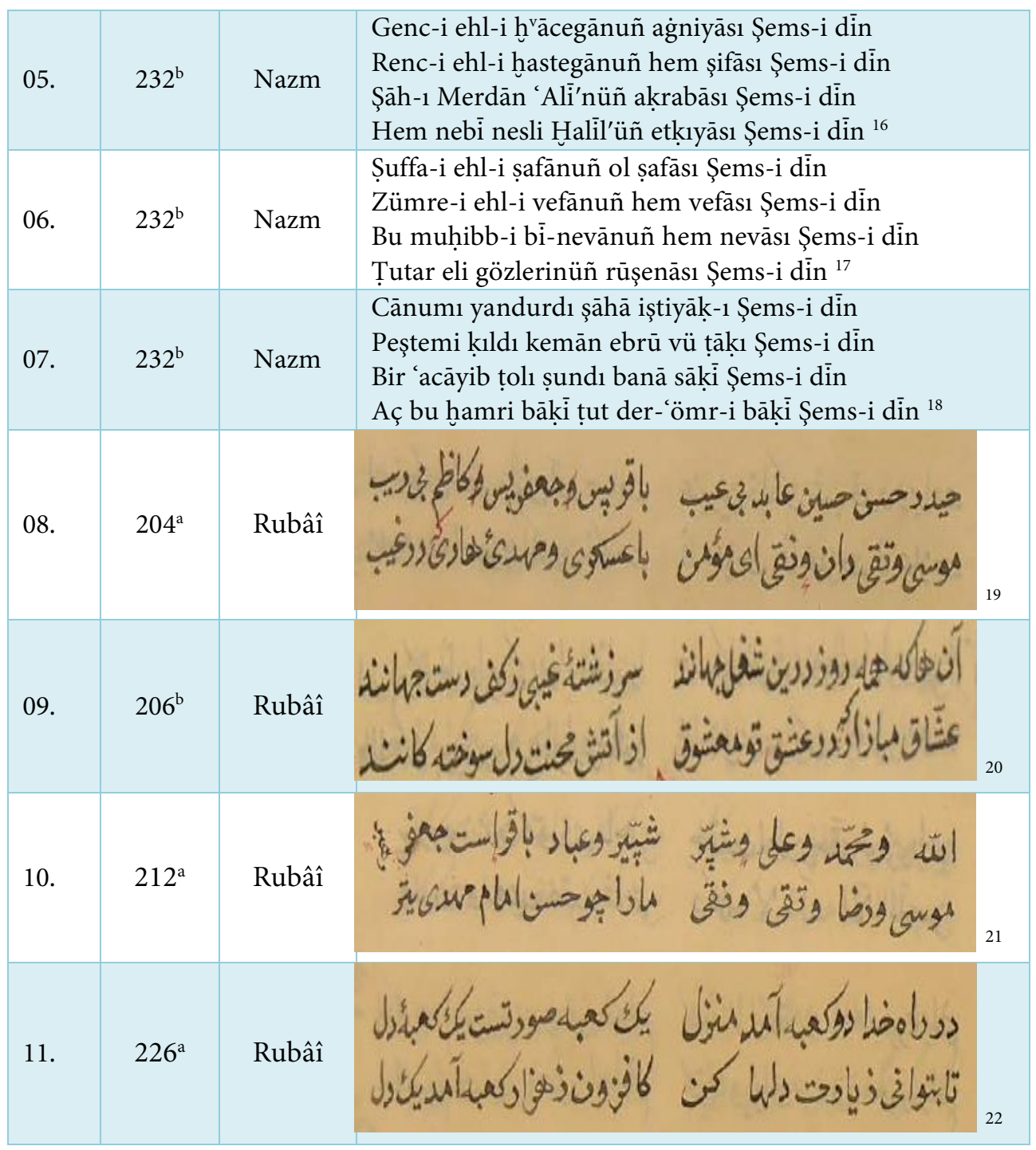

\footnotetext{
${ }^{16}$ fâilâtün fâilâtün fâilâtün fâilün

${ }^{17}$ fâilâtün fâilâtün fâilâtün fâilün

${ }^{18}$ fâilâtün fâilâtün fâilâtün fâilün

${ }^{19}$ Farsça rubâî.

${ }^{20}$ Farsça rubâî.

${ }^{21}$ Farsça rubâî.

${ }^{22}$ Farsça rubâî.
} 


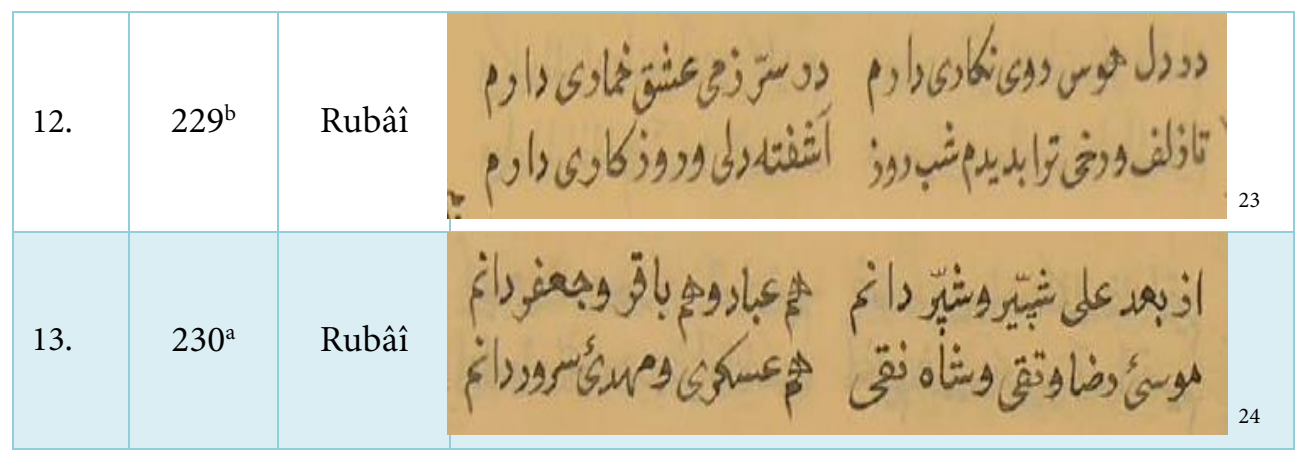

\section{b) ŞR Nüshasında Yer Alan Tuyuğlar ${ }^{25}$}

ŞR nüshasında yer alan tuyuğlar, $203^{\mathrm{b}}$ numaralı sayfada "rubâiyyât" başlğ̆ı altında yazılmış olup elif harfiyle kafiyelenmiş tuyuğlardan başlanarak alfabetik sıraya göre tertip edilmiş bir yazım yolu tercih edilmiştir. Rubâiyyât başlğ̆ı ile dört dizeden oluşan nazım şeklinin kastedildiği düşünülebilir. Zira bu başlık altında sadece tuyuğlar değil 4 dizeden oluşan diğer nazım şekilleri de vardır. Tuyuğ nazım şekli dışında yer alan bu şiirlerin nazım şekillerinin adları ve metinleri aşağıdaki tabloda yer almaktadır.

Aşağıda ŞR nüshasında $203^{\mathrm{b}}-241^{\mathrm{a}}$ varakları arasında "Rubâiyyât" başlı̆̆ı altında yazılan tüm şiirlerin ilk mısraları başlarına sıra numarası ve varak numarası da eklenerek listelenmiştir. "Rubâiyyât" başlı̆̆ı altında 597 şiir bulunmaktadır. Bu şiirlerin in 584'ü tuyuğdur. Yazmada yer alan tuyuğların 359'u daha önce yapılan neşirlerde mevcuttur. Burada yer alan 225 tuyuğ neşir çalışmalarında yoktur. "Rubâiyyât" başlığı altında yer alan ve tuyuğ dışındaki nazım şekilleriyle yazılan 13 şiirin 6'sı rubâî, 5'i nazm, 2'si iki beyitlik gazeldir.

\begin{tabular}{|c|c|c|c|c|}
\hline & \multicolumn{4}{|c|}{$\begin{array}{l}\text { ŞR Nüshasında Rubâiyyât Başlı̆̆ı Altında Yer Alan Şiirlerin } \\
\text { Nazım Şekillerine Göre Dağılımı }\end{array}$} \\
\hline \multirow{3}{*}{$\begin{array}{r}1000 \\
500 \\
0\end{array}$} & 584 & & & \\
\hline & & 6 & 5 & 2 \\
\hline & Tuyuğ & Rubâî & Nazm & İki Beyitlik Gazel \\
\hline
\end{tabular}

\footnotetext{
${ }^{23}$ Farsça rubâî.

${ }^{24}$ Farsça rubâî.

${ }^{25}$ Listede ŞR nüshasında yer alan tuyuğların ilk mısraları yazılmış ve mısra sonlarına eklenen dipnotta daha önce yapılan neşirlerde yer alanların kaynak adı ve sayfa numarası yazılmıştır.
} 


\section{ŞR Nüshasında Yer Alan Neşredilmemiş Tuyuğların Vezinleri}

Tuyuğ nazım şeklinin sadece fâilâtün fâilâtün fâilün vezni ile yazılmadığı başka vezinlerle de tuyuğ yazılmış olduğu neşredilmiş Nesîmî tuyuğları incelendiğinde görülecektir. Bu durum, tuyuğ yazan diğer şairlerin tuyuğları incelendiğinde de görülecektir. Mehmet Sait Çalka'nın tuyuğ konulu çalışmasında yer alan 1547 tuyuğdan 107'si mefâîlün mefâîlün feûlün, 12'si ise fe'ilâtün mefâilün feilün vezinleriyle yazılmıştır (Çalka 2019: 202-21). ŞR nüshasında yer alan 225 adet tuyuğdan 13'ünün fâilâtün fâilâtün fâilün vezni haricinde başka aruz kalıpları ile yazıldığı görülmektedir. 214 numaralı tuyuğun ise 1 ve 3. mısraları fâilâtün fâilâtün fâilün kalıbıyla 2. ve 4 . mısraları ise mefâillün mefâîlün feûlün vezniyle yazılmştır. Bu çalışma ile neşredilen 225 tuyuğun vezinlerinin dağılımı aşağıdaki grafikte gösterilmiştir.

\section{Neşirlerde Yer Almayan 225 Tuyuğun Vezinleri}

fâilâtün fâilâtün fâilün mefâilün mefâilün feûlün

feûlün feûlün feûlün feûl mefûlü mefâilün feûlün

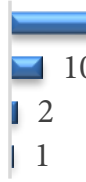

0

50

100

150

200

212

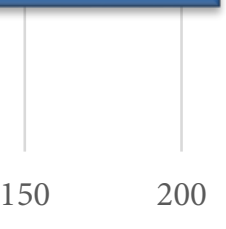

250

\section{ŞR Nüshasında Yer Alan Neşredilmemiş Tuyuğların Kafiye Düzeni}

Tuyuğ nazım şeklinin kafiye düzeni ile ilgili kaynaklarda birbirini tekrar eden bilgiler verilmekte ve genellikle aaxa kafiye düzeni ile yazıldığı belirtilmektedir. Türk edebiyatının en çok tuyuğ yazan şairi Nesîmî'nin tuyuğları için bu yaygın görüş geçerli değildir. Zira Nesîmî tuyuğlarının çoğunda musarra kafiyeleniş söz konusudur. Daha önce yapılan neşirlerde Nesîmî tuyuğlarının kafiye düzeni ile ilgili bilgiler verilmiştir. Mehmet Sait Çalka'nın çalışmasında yer alan 337 tuyuğun 304'ü, yüzdelik oranla \%90'1 musarra kafiyeleniş göstermektedir (Çalka 2019: 24). Aşağıda yer alan tabloda ŞR nüshasında yer alan neşredilmemiş Nesîmî tuyuğlarının kafiye düzeni ile ilgili sayısal veriler yer almaktadır. Bu verilere göre ŞR nüshasında yer alan tuyuğların \%78'i aaaa, $\% 49^{\prime}$ u aaxa, \%1,4'ü ise $a b a b$ kafiye düzeninde yazılmıştır.

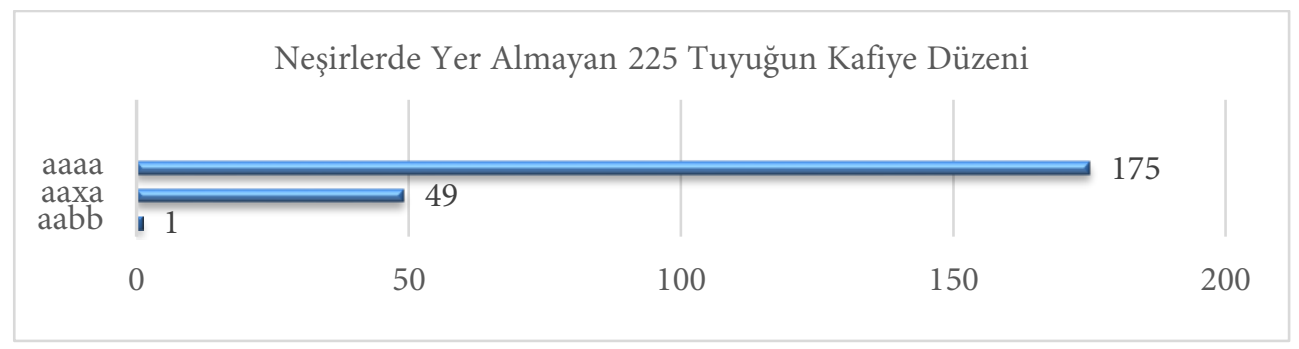




\section{ŞR Nüshasında "Rubâiyyat" Başlığı Altındaki Şiirlerin Nesîmî'ye Aidiyeti}

Nesîmî lirik şiirleri ve sıra dişı hayat hikâyesiyle Türk şiirinin tüm zamanlarda en çok sevilen ve aynı zamanda etkisi zamanını aşarak günümüze kadar gelebilen şairlerindendir. O, özellikle Alevi-Bektaşi çevrelerce tekke-tasavvuf geleneği içinde sevilen, şiirleri sözlü gelenekte de yaşayan bir şairdir. Nesimî'nin sevilen bir şair olması muakkiplerince taklit edilmesine ve aynı mahlası kullanan başka şairlerin ortaya çıkmasına yol açmıştır. Bunun sonucunda zaman içinde Nesîmî mahlasıyla yazılmış şiirlerin kime ait olduğu tartışmalı bir hâl almaya başlamıştır.

Şiir mecmularında ve cönklerde derleyici ya da müstensihlerin kendi edebî zevkleri ve meşreplerine göre şiir tercihi yaptıkları, şiirler üzerinde ve hatta mahlaslarda tasarrufta bulundukları mecmua ve cönk konularında çalışan araştırmacıların malumudur. Nesîmî mahlası kullandığı bilenen ve Seyyid Nesîmî yolundan giden şairlerden XVII. yüzyılda yaşamış olan Kul Nesîmî̀ye ait olduğu iddia edilen bazı şiirlerin aslında Seyyid Nesîmı̂'ye ait olduğu Ayan'ın hazırladı̆̆ı bir makale ile kanıtlanmıştır (Ayan 1974: 21-33). Öztelli'nin Kul Nesîmî ve şiirleri konusunda hazırladığı çalışmanın yeni baskısı yapıl(a)madığından Ayan'ın çalışmasıyla netleşen bilgiler ışı̆̆ında düzeltmelere de gidilmemiştir. (Öztelli 1969).

Neşredilmiş Nesîmî tuyuğlarının yer aldığı akademik çalışmaların listesi ve bu çalışmalarda yer alan tuyuğların sayısal bilgileri çalışmanın başında yer almaktadır. Bu yazının hazırlanmasında ve neşredilmemiş tuyuğların tespitinde bahsi geçen bu çalışmalar esas alınmıştır. Zira bu akademik çalışmaların her biri emek mahsulü olup alana katkı sağlayıcı önemli çalışmalardır. Her bir çalışma çeşitli Nesîmî Dîvânı yazma nüshalarının incelenmesine dayandırılarak ya da çeşitli şiir mecmuaları ya da cönklerden tespit edilen Nesîmî'nin şiirlerini ortaya koyan çalışmalardır. Bu sebeple ŞR nüshasındaki tuyuğların bu neşirlerde olup olmaması aynı zamanda araştırmacıların incelediği yazma nüshalarda olup olmadığını da ortaya koymaktadır. ŞR nüshasında yer alıp neşirlerde olmayan tuyuğların aynı zamanda yapılan neşir çalışmalarında kullanılan yazma nüshada olmadığını kabul etmek gerekir. Bu sebeple ŞR nüshasında yer alan ancak neşredilmiş çalışmalarda bulunmayan tuyuğların Nesîmî Dîvânı'nın diğer yazma nüshalarında bulunup bulunmadığını tespit etmeye yönelik nüsha mukayeseli bir çalışmaya gerek duyulmamıştır.

$\mathrm{Bu}$ çalışmada neşredilen 225 şiirin Ayan ve Qehremanov 'un hazırladığı Nesîmî Dîvânı çalışmalarında kullandıkları yazma nüshaların tamamında olmadığını düşünmek yanlış bir düşünce değildir. Zira bu çalışmalar pek çok yazma nüsha incelenerek ortaya konulmuş tenkitli metin çalışmalarıdır. Köksal ve Zülfe'nin neşredilmeyen Nesîmî tuyuğları konusunda hazırladıkları çalışmalar bahsi geçen bu çalışmalarda olmayan ancak çeşitli mecmualarda yer alan tuyuğların tespitiyle hazırlanan çalışmalardır. Mehmet Özdemir'in tanıtımını yaptığı Bodleian Libraries, 
MS. Turk. d. 34'te kayıtlı nüsha da daha önceki neşirlerle mukayeseli bir çalışma olup önceki çalışmalarda yer almayan şiirlerin tespitine ve neşrine yöneliktir. ŞR nüshasında yer alan ancak daha önce neşri yapılmamış tuyuğlar bütün bu neşirlerde ve neşirler dolasıyla incelenmiş yazma nüshalarda yer almadığından ŞR nüshası ile diğer Nesîmî Dîvânı nüshalarının ayrıca yazma mukayesesinin yapılmasına gerek duyulmamıştır.

Başka şairlere ait olduğu halde Nesîmî'ye ait olduğu sanılan ve ŞR nüshasında Nesîmî mahlasıyla kayıtlı şiirlerin varlığı yukarıda zikredilmişti. Bu durum nüshada yer alan tuyuğların da Nesîmî'ye aidiyetini sorgulamayı gerektirdiğinden yazmada yer alan neşredilmemiş tuyuğların başka şairlere ait olup olmadığı konusu tuyuğ yazan belli başlı şairlerin divanlarının incelenmesi suretiyle netliğe kavuşturulmaya çalışılmıştır. Bu çerçevede Mehmet Sait Çalka'nın çalışmasında yer alan ve Türk edebiyatında tuyuğ yazdığı tespit edilmiş 65 şairin tuyuğları ile ŞR nüshasında yer alan neşredilmemiş 225 tuyuğun mukayesesi yapılmıştır. Bu mukayese çalı̧ması sonucunda ŞR nüshasında yer alan ve bugüne kadar neşredilmeyen 225 tuyuğun 65 şairin tuyuğları ile örtüşmediği görülmüştür.

ŞR nüshasında yer alan neşredilmemiş 225 tuyuğun Nesîmî'ye aidiyeti sorgulanırken bu tuyuğların dil ve üslup açısından incelenmesi de gerekir. ŞR nüshasında yer alan bazı tuyuğların dil ve üslup özellikleri Nesîmî’ye aidiyeti konusunda şüphe duymamızı gerektirecek niteliktedir. ŞR nüshasında yer alan tuyuğlardan şairin kendini "abdâl-1 Rûm" olarak nitelendirdiği tuyuğların Nesîmîye ait olma ihtimali oldukça zayıftır ${ }^{26}$. Ayrıca nüshada yer alan ve daha önce yapılan neşir çalışmalarında da yer bulunan beş tuyuğun Ivaz Paşa Oğlu Atayi tuyuğları arasında yer alması da ŞR nüshasındaki bazı tuyuğların Nesîmî̀ye aidiyeti konusuna ihtiyatla bakmak gerektiği düşüncesini güçlendirmektedir ${ }^{27}$. Nesîmî tuyuğlarının dil, üslup ve muhteva özellikleri bakımından mütekâmil bir incelemesinin ancak yapılacak yeni ve eksiksiz bir Nesîmî Dîvânı neşrinden sonra mümkün olabileceği kanaatindeyiz.

Ahmet Talat Onay tuyuğ nazım şeklinin heceyle yazılan millî bir nazım şekli olduğunu ve hecenin her şekliyle yazıldığını iddia etmektedir (Onay 1996: 167). Cemal Kurnaz ve Halil Çeltik ise tuyuğun dörtlüklerden oluşan bir nazım şekli olmadığını, iki beyitlik gazel çeşidi kabul edilmesi gerektiğini ve tıpkı şarkı gibi bestelenmiş veya bestelenmek için yazılmış iki beyitlik manzumelerin genel adı olduğunu belirtirler (Kurnaz-Çeltik 2013:146-154). Bu görüşten hareketle Nesîmînnin tuyuğlarının hem

${ }^{26}$ Bkz: 210 Bizüz ol abdāl-1 Rūm ḥayrān u zār; 210ª Biz deli abdāl-1 Rūm'uz ey nigār; 212 ${ }^{\text {a }}$ Biz ki bir abdāl-1 Rūmuz ki faḳir; $214^{\mathrm{b}}$ Biz ol abdāl-1 Rūm-1 bì-nevāyuz

${ }^{27}$ Bkz: $208^{\mathrm{b}}$ 'Ārıż̇ yāruñ cinān būstānıdur; $211^{\mathrm{b}}$ Dilberā ḩațuñ gül-i handān durur; $219^{\mathrm{b}}$ 'Aş̣k ehli bì-ser ü sāmān gerek; $223^{\text {a }}$ Dỉde’i-i 'irfānı aç bīdār isen; $233^{\text {b }}$ Virmemek dil dilberüñ gìsūsına. İlk mısraları yazılan beş tuyuğ Ayan, Qəhrəmanov, Araslı, Sədiq neşirlerinde vardır. 
sözlü kültüre hem de halk şiirine yaklaştığını düşünebiliriz. Nesîmînin tuyuğları yazılı üretimin ürünleri olsa da tıpkı Yunus Emre, Hatâyî, Fuzûlî’nin şiirleri gibi geniş kitleleri etkileyen, şiirleri tekke/dergâh gibi ortamlarda sözlü gelenek içinde dolaşarak bugünlere gelmiş olabileceğini düşünmek yanlış bir bakış açısı olmayacaktır. Nesîmî aynı zamanda mensubu olduğu inancın ve öğretinin temsilcisi olarak sevilen, taklit edilen bir şairdir. Bu bağlamda halkın sözlü kültüründe ve tekke/tasavvuf edebiyatı çevrelerinde kısmen bir Nesîmî geleneği, tipi ya da tarzının oluştuğunu ve birden fazla Nesîmînnin varlığını düşünebiliriz. Nesîmînnin kendi kaleminden çıan bir şiirin ne ölçüde ilk halini muhafaza ettiği ve daha sonraki süreçlerde ne ölçüde değişiklikler gösterdiği kolay tespit edilebilecek bir durum değildir.

ŞR nüshasının tanıtımında da bahsedildiği üzere muahhar bir nüsha olduğunu düşündügümüz nüshada Fuzûlî, Halîlî, Surûrîye ait şiirlerin bulunduğunun not edildiği yazılmıştı. Muhsin Macit, Hatâyî Dîvânı'nın ŞR nüshasında yer alan 50 gazelinin neşrini konu alan çalışmasında mecmularda ve bazı divan nüshalarındaki şiirlerde Nesimî ile Hatâyî mahlasının yer değiştirmesine değinmiş ve Hatâyî mahlaslı şiirlerin Şah İsmail'e ait olup olmadığını belirleme konusunda divan yazmalarının da yeterince işlevsel olmadığı görüşünü dile getirmiştir (Macit 2016: 115-126). Bu durumun Nesimî için de geçerli olabileceğini ve Nesîmî mahlasıyla yazılmış ancak sözlü kültür içinde uğradığı değişim süreçlerinden dolayı ona aidiyeti şüpheli şiirlerin de Nesîmî Dîvânı yazmalarına girmiş olma ihtimalini göz ardı etmemek gerekir. Bu çalışma bilimsel süzgeçlerden geçerek ileride yapılacak olan Nesîmî Dîvânı neşirlerine katkı sunacak veya neşredilen bazı şiirlerin Nesîmîye ait olmadığı tespit edilse de bu şiirlerin ŞR nüshasında yer alma nedenleri üzerinde durularak yeni çalışmalara kapı aralayacaktır. Bu yönüyle çalışma Nesîmînnin etki alanına dair veriler sunmaya da hizmet etmiş olacaktır.

Aidiyetlik problemi halk şiiri sahasında da önemli bir açmaz olarak tartışılmış ve Karac'oğlan şiirlerinin kime ait olduğunun muhasebesinin yapılması yerine farklı bir perspektiften konunun ele alınması önerilmiştir. Bu problemin çözümlenmesinde halk şiiri sahasında da önemli araştırmalar yürütmüş olan İlhan Başgöz'ün "gelenekselleşme" (Başgöz 1986: 152-160) kavramı ile Öcal Oğuz’un “tipleşme” (Oğuz 2003: 31-38) kavramlarına müracaat edilerek Nesîmî şiirlerinin aidiyeti konusunda farklı bakış açıları geliştirilebilir.

Geniş kitleler tarafından sevilen büyük soluklu şairlerin şiirlerinin zamanla çoğalması, sözlü nakil süreçlerine dâhil olması ve şaire ait olmayan yeni şiirlerin de bu şairlere mal edilmesi kaçınılmaz bir durumdur. Zira bu şairler kendilerinden sonra gelenlerin duygu ve düşüncelerini, tabiata bakışlarını ve şiir dillerini derinden etkileyebilmektedir. Nesîmîye ait divan nüshaları ile şiir mecmuaları ya da cönklerde yer alan Nesîmî mahlaslı şiirlerin gerçekten bu şairlere ait olduğunu tespit etmenin 
kolay olmadığı bu konularda çalışmalar yapan araştırmacıların malumudur. Konu mahlas kullanılmayan nazım şekli olan tuyuğ olduğunda bu tespitin zorluk derecesi daha da artacaktır. Bu sebeple ŞR nüshasında yer alan şiirlere de ihtiyatla yaklaşmak icap eder. Bu ihtiyat payını ve şüpheci yaklaşımı muhafaza etmekle beraber ŞR nüshasında bulunan 225 tuyuğun aksini kantllayacak yeni bilgilere ya da verilere ulaşılıncaya kadar Nesîmî şiirleri, Nesîmî’ye atfedilen şiirler yahut meşkûk şiirler olarak kaydedilmelerinde bir sakınca olmadığ kanaatindeyiz.

\section{ŞR Nüshasında "Rubâiyyat" Başlığı Altındaki Şiirlerin Listesi}

ŞR nüshasında yer alan tuyuğ dışındaki manzumeler çalışmanın yukarıdaki sayfalarında "ŞR Nüshasında Yer Alan Tuyuğ Dışındaki Dört Dizelik Manzumeler" başlğ̆1 ile verilmişti. Tuyuğ nazım şekli dışındaki şiirlerin nazım şekilleri ve vezinleriyle ilgili notlar mısra sonlarına eklenen dipnotlarda gösterilmiştir. Tuyuğ nazım şekli ile yazılan biri mükerrer 597 şiirin daha önce yapılmış neşir çalışmalarında mevcut olanlarının kaynak ve sayfa numaraları dipnotlarda gösterilmiştir.

Bugüne kadar yapılan Nesîmî Dîvâmı ya da şiirlerini konu alan neşir çalışmalarında yer almayan tuyuğların da ilk mısraları yazılarak tam metinleri çalışmanın ilerleyen sayfalarında "Nesîmî Dîvânı ŞR Nüshasında Yer Alan Neşredilmemiş Tuyuğlar" başlığı altında verilmiştir. Aşağıdaki listede ŞR nüshasında bulunan tuyuğların nüshadaki varak numarası sıralaması dikkate alınarak hazırlanan ilk mısraları yer almaktadır. Mısra sonlarına eklenen dipnotların içeriğinde ise ilk mısraı verilen her bir tuyuğun daha önce neşredilmiş akademik çalışmalarda bulunanlarının yer aldıkları kaynak(lar) gösterilmiştir. Dipnot numarası olmayan mısralar daha önce yapılan neşir çalışmalarında bulunmayan manzumeleri ya da tuyuğları göstermektedir.

\section{Sayfa Varak Şiirlerin İlk Mısraları \\ No No}

\section{Harfü'1-Elif}

001. 203 $\quad$ Mazhhar-1 Hak oldı cümle māsivā

002. $203^{\mathrm{b}} \quad$ Ehl-i tațhìr olduñ-ise tạlibā

003. 203 $3^{\mathrm{b}}$ Cehd ḳl ol ey 'azīiüm mehci'ā

004. $203^{\text {b }}$ Gel ki müştāk olmuşam dīdāruña ${ }^{28}$

005. $203^{\mathrm{b}} \quad$ Kim ki beñzetdi hilāli ḳaşuña

006. $203^{\mathrm{b}} \quad$ Bỉ-vefāsız dünyede umma vefă ${ }^{29}$

\footnotetext{
${ }^{28}$ Ayan, s. 801; Qəhrəmanov, C. II, s. 468; Arasl, C. II, s. 263; Sədiq, s. 430.

${ }^{29}$ Ayan, s. 801 ; Sədiq, s. 429. Bu tuyuğ $203^{\text {bh }}$ kenarda kayıtlıdır. Kenarında kayıtlı şiirlerin varak numarası burada olduğu gibi $\left(203^{\text {bh }}=203^{\text {bhaşive }}\right.$ şeklinde $)$ gösterilmiștir.
} 
007. 203 $\quad$ Dünyeye çün cífe didi Mușțafā ${ }^{\text {bh }}$

008. $203^{\text {bh }} \quad$ Șūretüñ kimdür kemāhỉ Muștafāā

009. $\quad 203^{\text {bh }} \quad$ Ey saçuñ $v e^{\prime} l-l e y l$ ü yüzüñ $v e^{\prime} d-d u h \bar{a}^{31}$

010. $203^{\text {bh }} \quad$ Ey güzel cāna yeter eyle cefā

011. 203 $3^{\text {bh }} \quad$ Ey cemālüñ maẓharı zāt-1 Hudāa ${ }^{32}$

012. 203 'Aş̧̣-ile geldi cemi' ${ }^{\text {bh }}$-i evliyà ${ }^{33}$

013. 203 ${ }^{\text {bh }}$ Beñzeye mi māh-1 tābān alnuña ${ }^{34}$

014. $203^{\text {bh }} \quad$ Kim elif didi vü kim hạa boyuña ${ }^{35}$

015. 203 $\quad 203^{\mathrm{b}} \quad$ Ey yüzün min indihi ümmü'l-kitāb ${ }^{36}$

016. $203^{\mathrm{b}} \quad$ Yanaguñ nūrına hayrān āfitāb

017. 204 $\quad$ Ey habīibi cānib-i Hạk'dan hițāb

018. 204 20 ä̈nki yüzüñden götürüldi hicāb

019. 204 20 Zāhidā esmā içün ḳılsañ itāb

020. 204 $\quad 24^{\mathrm{a}} \quad$ Efendim $^{37}$ vefālu gerekdür habīib

021. 204 $\quad$ Haydar u Hasen Hüseyn 'Ảbid bì-'ayb

022. $204^{\mathrm{a}} \quad$ İy saçuñ devrinde mestūr āfitāb ${ }^{38}$

023. 204 20 İy yañagiundan münevver āfitāb ${ }^{39}$

024. 204 20 İy ḳamer yüzlü götür Ḥak'dan niḳāb ${ }^{40}$

025. $204^{\mathrm{b}} \quad$ Ey özinden bì-ḩaber gà̆fil garīi ${ }^{41}$

\section{Ḥarfü't-Tà}

026. 204 $\quad$ Ey ruhuñ 'aşḳında 'aḳluñ şāh-māt ${ }^{42}$

027. 204 ${ }^{\text {b }}$ Kāf u nūn emrinden oldı kā'ināt ${ }^{43}$

028. $204^{\text {b }} \quad$ Ey ḩatuñ Ḥiżr u lebüñ āb-1 hayāt ${ }^{44}$

\footnotetext{
${ }^{30}$ Ayan, s. 801; Sədiq, s. 429.

${ }^{31}$ Qəhrəmanov, C. II, s. 606; Qəhrəmanov, C. III, s. 161; Araslı, C. II, s. 263; Köksal (2000) s. 190.

${ }^{32}$ Qəhrəmanov, C. II, s. 606.

${ }^{33}$ Qəhrəmanov, C. III, s. 161; Arasl1, C. II, s. 263; Sədiq, s. 431.

${ }^{34}$ Zülfe (2005), s. 23.

${ }^{35}$ Ayan, s. 801.

${ }^{36}$ Ayan, s. 801; Qəhrəmanov, C. II, s. 363; Arasl, C. II, s. 263; Sədiq, s. 431.

37 efendüm: bize ol; ŞR.

${ }^{38}$ Ayan, s. 802; Qəhrəmanov, C. II, s. 361; Arasl1, C. II, s. 263; Sədiq, s. 431.

${ }^{39}$ Ayan, s. 802; Qəhrəmanov, C. II, s. 361; Arasl1, C. II, s. 263; Sədiq, s. 431.

${ }^{40}$ Ayan, s. 802; Qəhrəmanov, C. II, s. 363; Arasl1, C. II, s. 264; Sədiq, s. 431.

${ }^{41}$ Ayan, s. 802; Qəhrəmanov, C. II, s. 362; Arasl1, C. II, s. 264; Sədiq, s. 431.

${ }^{42}$ Ayan, s. 803; Qəhrəmanov, C. II, s. 365; Araslı, C. II, s. 264; Sədiq, s. 432.

${ }^{43}$ Ayan, s. 803; Qəhrəmanov, C. II, s. 364; Arasl, C. II, s. 265; Sədiq, s. 432.

${ }^{44}$ Ayan, s. 803; Qəhrəmanov, C. II, s. 365; Arasl, C. II, s. 264; Sədiq, s. 433.
} 
029. 204 $\quad$ Bir iki üç gün cihāndur cāy-1 geșt ${ }^{45}$

030. $204^{\mathrm{b}}$ Gelmişem keâlū belādan mey-perest ${ }^{46}$

031. 204 $4^{\text {bh }}$ Gözlerüñ ‘àşıkları ḳılur memāt

032. 205 Ey meyi ' İsā-lebüñ 'aynu'l-hayāt

033. 205 20 [demi] 'İsā-lebüñ āb-1 hayāt

034. 205 $\quad$ Márifetdür țālibā āb-1 hayāt

035. 205 a ${ }^{\mathrm{a}} \quad \mathrm{Al}$ elinden atin[1] yabana at ${ }^{47}$

036. 205 2 Bu hurūfdur otuz iki müfredāt

037. 205 $\quad$ Zulmet içre hạaṣıl itdüm ben hayāt

038. 205 $\quad$ au bisāṭ-1 'aş̣ imiş şatranc-1 zāăt ${ }^{48}$

039. $205^{\mathrm{b}} \quad$ Ey dişüñ lü’lü’ lebüñ àb-1 hayāt

040. $205^{\mathrm{b}} \quad$ Kur a-i -i devletde oynat ey dil at

041. 205 ${ }^{\mathrm{b}} \quad$ Kim ezel 'ahdinde șādıḳdur dürüst

042. 205 $\quad$ Yüzüñ devrinde hatm oldı 'alāmet ${ }^{49}$

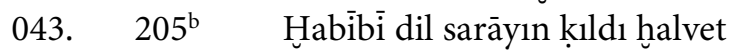

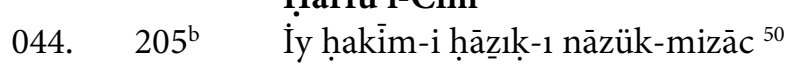

\section{Ḥarfü'l-ب̣ā}

045. 205 $\quad$ Toggdı mag̉ribden güneş indi Mesih ${ }^{\mathrm{b}}$

046. 206 ${ }^{\mathrm{a}}$ Sākīi gül-ruh elinden bir ḳadeh ${ }^{52}$

\section{Ḥarfü'l-Hูā}

047. 206 20 Talmışam şol bahre kim pāyānı yoh ${ }^{53}$

048. 206 ${ }^{\mathrm{a}}$ Derdine āşı̣lklaruñ dermānı yoh ${ }^{54}$

049. $206^{\mathrm{a}}$ Göñlümi yağmāladı şol āli çoh ${ }^{55}$

\footnotetext{
45 Ayan, s. 804; Qəhrəmanov, C. II, s. 368; Arasl, C. II, s. 264; Sədiq, s. 432.

${ }^{46}$ Ayan, s. 803; Qəhrəmanov, C. II, s. 367; Arasl, C. II, s. 265; Sədiq, s. 432.

${ }^{47}$ Ayan, s. 803; Qəhrəmanov, C. II, s. 364; Sədiq, s. 433.

${ }^{48}$ Qəhrəmanov, C. III, s. 162; Arasli, C. II, s. 265; Sədiq, s. 432.

${ }^{49}$ mefầlün mefâillün feûlün

${ }^{50}$ Ayan, s. 804; Qəhrəmanov, C. II, s. 368; Arasl, C. II, s. 265; Sədiq, s. 434.

${ }^{51}$ Ayan, s. 805; Qəhrəmanov, C. II, s. 369; Arasli, C. II, s. 265; Sədiq, s. 434.

${ }^{52}$ Ayan, s. 805; Qəhrəmanov, C. II, s. 369; Arasl, C. II, s. 266.

${ }^{53}$ Ayan, s. 805; Qəhrəmanov, C. II, s. 371; Araslı, C. II, s. 266; Sədiq, s. 433.

${ }^{54}$ Ayan, s. 805; Qəhrəmanov, C. II, s. 370; Arasli, C. II, s. 266; Sədiq, s. 433.

${ }^{55}$ Ayan, s. 805; Qəhrəmanov, C. II, s. 370; Arasl, C. II, s. 266; Sədiq, s. 433.
} 


\section{Harfü'd-Dāl}

050. 206 $\quad$ Ey boyuñ țūbā yüzüñ dārü'l-hnulūd ${ }^{56}$

051. 206 $\quad$ Ey cemālüñ kul hüva'llāhu ehad ${ }^{57}$

052. 206 $\quad$ Ey șaçuñ mahş̧er yüzüñ dārü'l-hulūd ${ }^{58}$

053. $206^{\mathrm{b}} \quad$ Ey ezel nūrı cemālüñ tā-ebed ${ }^{59}$

054. $206^{\mathrm{b}} \quad$ Kim ki oldı țâli i i Haḳ'dan sa īd ${ }^{60}$

055. 206 $\quad 20$ cemālüñ kāf $u$ hā yā 'ayn șād ${ }^{\text {b1 }}$

056. $206^{\mathrm{b}} \quad$ Kutlu olsun server-i baht-1 cedid

057. $206^{\mathrm{b}}$

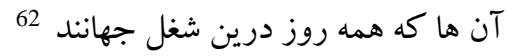

\section{Harfü'r-Rā}

058. 206 $\quad 2$ Āb u hāki eyledi çün Hak hamì ${ }^{\text {b3 }}$

059. $\quad 206^{\mathrm{b}} \quad$ Ay-ile güneş yüzüñ hayrānıdur ${ }^{64}$

060. 207 20 ä̈ Hak Ḥk' $^{\mathrm{a}}$ her yerde eydürsen ki var ${ }^{65}$

061. $207^{\mathrm{a}} \quad$ Ey harāmi gözlerüñ yaġmācılar ${ }^{66}$

062. 207 $\quad$ Ey iki ālemde hüsnüñ bi

063. $\quad 207^{\mathrm{a}} \quad$ Ey cemālüñ hüsnine hayrān ḳamer ${ }^{68}$

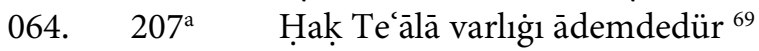

065. 207 $207^{\mathrm{a}} \quad$ Ey güneş yüzlü cemālüñ fitnedür ${ }^{70}$

066. 207 $\quad 207^{\mathrm{a}} \quad$ Ey göñül Ḥak sendedür Ḥak sendedür ${ }^{71}$

067. $207^{\mathrm{b}} \quad$ Ey saçuñ her tārına biñ cān esīr ${ }^{72}$

${ }^{56}$ Ayan, s. 806; Qəhrəmanov, C. II, s. 373; Araslı, C. II, s. 266; Sədiq, s. 434.

${ }^{57}$ Ayan, s. 806; Qəhrəmanov, C. II, s. 372; Arasli, C. II, s. 266; Sədiq, s. 434.

${ }^{58}$ Qəhrəmanov, C. II, s. 373; Arasli, C. II, s. 266.

${ }^{59}$ Ayan, s. 806; Qəhrəmanov, C. II, s. 372; Arasl, C. II, s. 267; Sədiq, s. 434.

${ }^{60}$ Ayan, s. 806; Qəhrəmanov, C. II, s. 374; Arasl, C. II, s. 266; Sədiq, s. 435.

${ }^{61}$ Ayan, s. 807; Qəhrəmanov, C. III, s. 163; Araslı, C. II, s. 267; Sədiq, s. 434.

${ }^{62}$ Farsça yazılmış rubâi.

${ }^{63}$ Ayan, s. 817; Qəhrəmanov, C. II, s. 395; Arasl, C. II, s. 267; Sədiq, s. 438.

${ }^{64}$ Ayan, s. 814; Qəhrəmanov, C. II, s. 374; Arasli, C. II, s. 270; Sədiq, s. 443.

${ }^{65}$ Ayan, s. 814; Qəhrəmanov, C. II, s. 396; Arasl, C. II, s. 267; Sədiq, s. 436.

${ }^{66}$ Ayan, s. 814; Qəhrəmanov, C. II, s. 382; Arasl, C. II, s. 270; Sədiq, s. 436.

${ }^{67}$ Ayan, s. 812; Qəhrəmanov, C. II, s. 384; Arasl, C. II, s. 270; Sədiq, s. 439.

${ }^{68}$ Ayan, s. 818; Qəhrəmanov, C. II, s. 392; Arasl, C. II, s. 271; Sədiq, s. 435.

${ }^{69}$ Ayan, s. 811; Qəhrəmanov, C. II, s. 607; Arasl, C. II, s. 268; Sədiq, s. 440.

${ }^{70}$ Ayan, s. 817; Qəhrəmanov, C. II, s. 397; Arasl, C. II, s. 271; Sədiq, s. 441.

${ }^{71}$ Ayan, s. 808; Qəhrəmanov, C. II, s. 379; Qəhrəmanov, C. III, s. 163; Araslı, C. II, s. 268; Sədiq, s. 440.

${ }^{72}$ Ayan, s. 813; Qəhrəmanov, C. II, s. 396; Arasl, C. II, s. 273; Sədiq, s. 438.

Tuyuğun ilk iki dizeleri Qəhrəmanov C. II, s. 610'da yer alan başka bir tuyuğ ile aynıdır. 3. ve 4. dizeler farklıdır. 
068. 207 $\quad 207^{\mathrm{b}} \quad$ Eüneș șūretlü yār-1 dil-peżīi ${ }^{73}$

069. $207^{\mathrm{b}} \quad$ Cevher-i ferd ādemüñ kānındadur ${ }^{74}$

070. 207 $\quad$ Hak Te ālā'nuñ kelāmı nūrdur ${ }^{75}$

071. $207^{\mathrm{b}} \quad$ Hak Te ālā'nuñ kelāmı sendedür ${ }^{76}$

072. 207 $\quad$ Hak Te ālā Ādem og̉l özidür ${ }^{77}$

073. $207^{\mathrm{b}} \quad$ Haḳk $k^{\prime}$ yār ol kim saña yār ol yeter ${ }^{78}$

074. $207^{\text {bh }}$ Maȟzen-i șıdk u șafā sineñdedür ${ }^{79}$

075. $207^{\text {bh }} \quad$ Hak Te ālā'nuñ șifātı sendedür

076. $\quad 208^{\mathrm{a}} \quad V e^{\prime} d$ de duhānuñ āfitābı yüzidür ${ }^{80}$

077. 208 $\quad$ a $\quad$ Çün vücūduñdur nigāāa şehriyār ${ }^{81}$

078. 208 $\quad$ Her ne yerde gökde var ādemde var ${ }^{82}$

079. $208^{\mathrm{a}} \quad$ Cennetüñ devri yüzüñ gülzārıdur ${ }^{83}$

080. 208 ${ }^{\mathrm{a}} \quad$ Țutdı yüzüñden cihānı cümle nūr ${ }^{84}$

081. 208 2 Şem ine güneş yüzüñ pervānedür ${ }^{85}$

082. $208^{\mathrm{a}} \quad$ Şol ḳaşı Çaçı büt-i meh-veş gelür ${ }^{86}$

083. 208 $\quad 20$ Șūretüñ levḥinde Hak ḳı ḳldı zuhūr ${ }^{87}$

084. 208 $\quad$ Șūretüñ Muṣhaf'dur iy bedr-i münīi ${ }^{88}$

085. $208^{\mathrm{b}} \quad$ 'Āriżı yāruñ cinān būstānıdur ${ }^{89}$

086. $208^{\mathrm{b}} \quad$ 'Āşı k̦uñ seyrānı ol 'ālemdedür ${ }^{90}$

087. $208^{\mathrm{b}}$ 'Aḳreb oldı ālemüñ halḳı vü mār ${ }^{91}$

\footnotetext{
73 Ayan, s. 808; Qəhrəmanov, C. II, s. 395; Araslı, C. II, s. 270; Sədiq, s. 439.

${ }^{74}$ Ayan, s. 809; Qəhrəmanov, C. II, s. 387; Arasl1, C. II, s. 268; Sədiq, s. 439.

${ }^{75}$ Ayan, s. 813; Qəhrəmanov, C. II, s. 376; Arasl1, C. II, s. 269.

${ }^{76}$ Ayan, s. 808; Qəhrəmanov, C. II, s. 382; Arasli, C. II, s. 268; Sədiq, s. 440.

77 Ayan, s. 809; Qəhrəmanov, C. II, s. 380; Araslı, C. II, s. 273; Sədiq, s. 437.

${ }^{78}$ Ayan, s. 807; Qəhrəmanov, C. II, s. 383; Arasl, C. II, s. 270; Sədiq, s. 437.

${ }^{79}$ Ayan, s. 810; Qəhrəmanov, C. II, s. 389; Araslı, C. II, s. 274; Sədiq, s. 440; Zülfe (2005), s. 131.

${ }^{80}$ Ayan, s. 809; Qəhrəmanov, C. III, s. 166. yüzidür: yüz durur; Qəhrəmanov.

${ }^{81}$ Ayan, s. 815; Qəhrəmanov, C. III, s. 168; Arasl, C. II, s. 272; Sədiq, s. 436.

82 Ayan, s. 811; Qəhrəmanov, C. III, s. 170; Arasl, C. II, s. 273.

${ }^{83}$ Ayan, s. 815; Qəhrəmanov, C. II, s. 377; Arasl, C. II, s. 273; Sədiq, s. 442.

${ }^{84}$ Ayan, s. 814; Qəhrəmanov, C. II, s. 375; Arasl1, C. II, s. 269.

${ }^{85}$ Ayan, s. 816; Qəhrəmanov, C. II, s. 381; Arasl1, C. II, s. 272; Sədiq, s. 441.

${ }^{86}$ Ayan, s. 807; Qəhrəmanov, C. II, s. 391; Arasl1, C. II, s. 273; Sədiq, s. 444.

${ }^{87}$ Ayan, s. 817; Qəhrəmanov, C. II, s. 608; Arasl1, C. II, s. 269; Sədiq, s. 438.

${ }^{88}$ Ayan, s. 807; Qəhrəmanov, C. II, s. 387; Araslı, C. II, s. 270; Sədiq, s. 438.

${ }^{89}$ Ayan, s. 816; Qəhrəmanov, C. II, s. 394; Araslı, C. II, s. 274; Sədiq, s. 443. Bu tuyuğ Ivaz Paşa Oğlu Atayi tuyuğları arasında da yer almaktadır. Arslan, Uzeyir (2016), s. 178-80.

${ }^{90}$ Ayan, s. 817; Qəhrəmanov, C. II, s. 388; Arasl, C. II, s. 268; Sədiq, s. 439.

${ }^{91}$ Ayan, s. 816; Qəhrəmanov, C. II, s. 393; Arasl, C. II, s. 272; Sədiq, s. 435.
} 


\begin{tabular}{|c|c|c|}
\hline 088. & $208^{\mathrm{b}}$ & Ḳıldı insān maẓharından Haḳ ẓuhūr ${ }^{92}$ \\
\hline 089. & $208^{\mathrm{b}}$ & Çün zamāne geldi geçdi yoḳ medār ${ }^{93}$ \\
\hline 090. & $208^{\mathrm{b}}$ & Ey cemālüñ otuz iki hatṭ-ı nūr \\
\hline 091. & $209^{a}$ & Fitnenüñ baş1 gözüñ sevdāsıdur ${ }^{94}$ \\
\hline 092. & $209^{\mathrm{a}}$ & Fitnedür 'aynuñ yüzüñ şems ü ḳamer ${ }^{95}$ \\
\hline 093. & $209^{\mathrm{a}}$ & Kāmetüñ her dem ḳıyāmet gösterür ${ }^{96}$ \\
\hline 094. & $209^{\mathrm{a}}$ & Kābe ḳavseyn iki ḳaşuñ yayıdur ${ }^{97}$ \\
\hline 095. & $209^{\mathrm{a}}$ & Kāâ u nūn ma'nīde küllī ma níidür ${ }^{98}$ \\
\hline 096. & $209^{\mathrm{a}}$ & Ger Ḥaḳ olduñ Ḥaḳ sıfātuñ ḳandadur 99 \\
\hline 097. & $209^{\mathrm{a}}$ & Gel muhīṭ-i 'aşḳa bir kez țala gör ${ }^{100}$ \\
\hline 098. & $209^{\mathrm{b}}$ & Gel ki sensen 'arş u kürsì sendedür ${ }^{101}$ \\
\hline 099. & $209^{\mathrm{b}}$ & Māhumuñ yüzinden oldı perde dūr 102 \\
\hline 100. & $209^{\mathrm{b}}$ & Her ne kim taḳdīr-i Yezdānī ḳılur ${ }^{103}$ \\
\hline 101. & $209^{\mathrm{b}}$ & Ey cemālüñ Ka'be hatțuñ hāciler ${ }^{104}$ \\
\hline 102. & $209^{\mathrm{b}}$ & Sî̀ vü dü dendān çü dürr-i ābdār 105 \\
\hline 103. & $209^{\mathrm{b}}$ & Çāh-1 Bābil çün zenahdānındadur 106 \\
\hline 104. & $209^{\mathrm{b}}$ & Yār elinden çün mey-i dil-keş gelür ${ }^{107}$ \\
\hline 105. & $209^{\text {bh }}$ & Șāf içen dā’im șafā ḥāṣıl ḳılur ${ }^{108}$ \\
\hline 106. & $210^{\mathrm{a}}$ & Sī vü dü çünki kelām-1 Kirdigār \\
\hline 107. & $210^{\mathrm{a}}$ & 'Arş u ferş [u] mā-siva'llăh ne ki var \\
\hline 108. & $210^{\mathrm{a}}$ & Senden özge kim didi ‘ālemde var \\
\hline 109. & $210^{\mathrm{a}}$ & Șūret ü ma'nā durur her ne ki var \\
\hline 110. & $210^{a}$ & Bizüz ol abdāl-1 Rūm ḥayrān u zār \\
\hline
\end{tabular}

${ }^{92}$ Ayan, s. 815; Qəhrəmanov, C. III, s. 165. Qəhrəmanov neşrinde kelimeler farklıdır.

93 Ayan, s. 811; Qəhrəmanov, C. II, s. 609; Qəhrəmanov, C. III, s. 163; Arasl, C. II, s. 267; Sədiq, s. 436. Qəhrəmanov neşrinde kelime farklıklıkları görülmektedir.

${ }^{94}$ Ayan, s. 808 Qəhrəmanov, C. II, s. 381; Arasl, C. II, s. 272; Sədiq, s. 442

${ }^{95}$ Ayan, s. 818; Qəhrəmanov, C. II, s. 391; Arasl, C. II, s. 272; Sədiq, s. 435.

${ }^{96}$ Ayan, s. 815; Qəhrəmanov, C. II, s. 390; Arasli, C. II, s. 271; Sədiq, s. 444.

${ }^{97}$ Ayan, s. 814; Qəhrəmanov, C. II, s. 394; Arasli, C. II, s. 271; Sədiq, s. 444.

${ }^{98}$ Ayan, s. 816; Qəhrəmanov, C. II, s. 376; Arasl, C. II, s. 273; Sədiq, s. 443.

${ }^{99}$ Ayan, s. 811; Qəhrəmanov, C. II, s. 389; Arasl, C. II, s. 268.

${ }^{100}$ Ayan, s. 812; Qəhrəmanov, C. II, s. 390; Arasli, C. II, s. 267; Sədiq, s. 438.

${ }^{101}$ Ayan, s. 808; Qəhrəmanov, C. II, s. 393; Arasli, C. II, s. 268; Sədiq, s. 440.

102 Ayan, s. 817; Qəhrəmanov, C. II, s. 392; Arasl, C. II, s. 269; Sədiq, s. 437.

${ }^{103}$ Ayan, s. 818; Qəhrəmanov, C. II, s. 378; Araslı, C. II, s. 269; Sədiq, s. 444.

${ }^{104}$ Qəhrəmanov, C. II, s. 386; Sədiq, s. 437.

${ }^{105}$ Qəhrəmanov, C. II, s. 384; Arasli C. II, s. 275; Sədiq, s. 436.

${ }^{106}$ Ayan, s. 810; Qəhrəmanov, C. II, s. 385.

107 Ayan, s. 807; Qəhrəmanov, C. II, s. 385; Arasl, C. II, s. 267.

${ }^{108}$ Ayan, s. 813; Qəhrəmanov, C. II, s. 609; Qəhrəmanov, C. III, s. 171; Arasl, C. II, s. 274; Sədiq, s. 444. 
111. 210 $\quad$ Biz deli abdāl-1 Rūm'uz ey nigār

112. $210^{\mathrm{a}}$ Haḳ kelāmı kendi nūrumdur ey yār

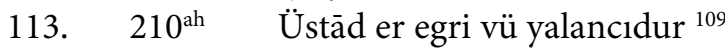

114. $210^{\mathrm{b}}$ Dürr-i deryā-yı țarikāàt bendedür

115. $210^{\mathrm{b}} \quad$ Küntü kenzün ma'nisisi ādemdedür

116. $210^{\mathrm{b}}$ Ey gönül Ḥaḳ muṭlaḳ ol dilberdedür

117. $210^{\mathrm{b}} \quad$ Ḥak sözin gör kim nice dür-dānedür ${ }^{110}$

118. $210^{\mathrm{b}} \quad$ Sünbülüñ kim șad hezārān destedür

119. $210^{\mathrm{b}} \quad$ Gamzeñ oḳı cānuma peyvestedür

120. $210^{\mathrm{b}} \quad$ Çünki ḳış geçdi teveccüh yazadur ${ }^{111}$

121. $210^{\text {bh }} \quad$ 'Ārifüñ cānı șadef 'irfānıdur ${ }^{112}$

122. $210^{\text {bh }} \quad$ Ger saña erden irişmeye naẓar ${ }^{113}$

123. $210^{\text {bh }}$ Ol nedür kim ayağ başındadur

124. $210^{\text {bh }} \quad$ 'Așkuñ odına göñül pervānedür ${ }^{114}$

125. $211^{\text {a }} \quad$ Haberler içre bu bir hoş ḩaberdür

126. $211^{\text {a }} \quad$ Bil vücūduñ kim Süleymān tahtıdur ${ }^{115}$

127. 211 $211^{\text {a }}$ Çün cemālüñ kün fekānuñ zaātıdur

128. $211^{\mathrm{a}} \quad$ Si vü dü çünkim cihānda bākidür

129. $211^{\text {a }} \quad$ Bugün uş yār benümle yār olupdur

130. 211 $\quad$ Șubḥ u şām 'āşı̣laruñ seyrānıdur

131. 211 $\quad$ Her kişi kim șạhịib-i idrāk olur

132. $211^{\text {ah }} \quad$ Ey göñül tā gerdişüñ bünyādıdur ${ }^{116}$

133. $211^{\text {ah }} \quad$ Ehl-i 'irfān ādemi cān-bahşşdur ${ }^{117}$

134. $211^{\mathrm{b}}$ Gice gündüz 'aşk eri bỉdār olur

135. 211 ${ }^{\text {b }}$ Aç gözüñi fażl-1 Hak' dan cūdı gör

136. $211^{\mathrm{b}}$ Aç gözüñ her yerde kāf u nūnı gör

137. $211^{\mathrm{b}}$ 'Ākil iseñ aç gözüñi ānı gör

138. $211^{\mathrm{b}} \quad$ Lebüñe la la l-i cān-fezā didiler ${ }^{118}$

\footnotetext{
109 Ayan, s. 812; Qəhrəmanov, C. III, s. 166; Arasl, C. II, s. 270; Sədiq, s. 442.

${ }^{110}$ Ayan, s. 811; Qəhrəmanov, C. III, s. 164; Arasl, C. II, s. 269; Sədiq, s. 441.

111 Ayan, s. 810.

112 Ayan, s. 809.

113 Ayan, s. 810.

114 Ayan, s. 809.

${ }^{115}$ Qəhrəmanov, C. III, s. 165; Arasl, C. II, s. 269; Sədiq, s. 441.

116 Ayan, s. 810.

117 Ayan, s. 809.

${ }^{118}$ Qəhrəmanov, C. III, s. 166; Arasli, C. II, s. 270.
} 
139. $211^{\mathrm{b}} \quad$ Dilberā hațuñ gül-i handān durur ${ }^{119}$

140. $211^{\text {b }}$ Sāye-i ẓlluñ hümāsı gün durur

141. $212^{\mathrm{a}} \quad$ Ey ḳarındaş bil ölüm uyhu durur

142. 212 $\quad$ Biz ki bir abdāl-1 Rūmuz ki faḳir

143. $212^{\mathrm{a}}$ 'Āşıkuñ adı neden oldı faḳī

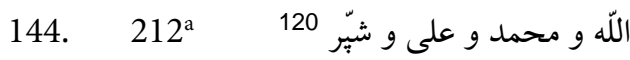

145. $212^{\mathrm{a}} \quad$ Sende senlikden nice kim var eser

146. $212^{\mathrm{a}}$ Çün cemālüñ cennetüñ gülzārıdur ${ }^{121}$

147. $212^{\mathrm{a}} \quad$ Perde çekmiş ara yerde perde var ${ }^{122}$

\section{Harfü'z-Zā}

148. 212 $\quad$ Şāh-1 merdān 'Alī'dür sultānumuz

149. $212^{\mathrm{b}} \quad$ Fażl-1 Hak 'dur vāḳıf-ı esrārumız ${ }^{123}$

150. $212^{\mathrm{b}}$ Fā vü żàd u lāma düşdi göñlümüz ${ }^{124}$

151. $212^{\mathrm{b}}$ Perde yüzinden götürdi māhumız ${ }^{125}$

152. $212^{\mathrm{b}}$ Ey cemālüñ șūret-i Raḥmān'umuz ${ }^{126}$

153. $212^{\mathrm{b}}$ Sensüz ey cān göñlüm ārām eylemez ${ }^{127}$

154. $212^{\mathrm{b}}$ Ey yüzi gül dili bülbül şāhumuz

155. $\quad 213^{\mathrm{a}} \quad$ Bir 'acāyib şāha düşdi göñlümüz ${ }^{128}$

156. $213^{\text {a }}$ Yine bir sulțāna düşdi göñlümüz ${ }^{129}$

157. $213^{\mathrm{a}} \quad$ Yine bir dildāra düşdi göñlümüz ${ }^{130}$

158. 213 $\quad$ 'Ayn u şin u kāa düşsdi göñlümüz

159. $213^{\mathrm{a}} \quad$ Gözleri şehlāya düşdi göñlümüz

160. $213^{\mathrm{a}} \quad$ Fā vü żād u lāma düşdi göñlümüz ${ }^{131}$

\footnotetext{
${ }^{119}$ Qəhrəmanov, C. II, s. 375; Araslı, C. II, s. 274; Sədiq, s. 442. Bu tuyuğ Ivaz Paşa Oğlu Atayi tuyuğları arasında da yer almaktadır. Arslan, Uzeyir (2016), s. 178-80.

${ }^{120}$ Farsça rubâi.

${ }^{121}$ Qəhrəmanov, C. II, s. 383; Arasli, C. II, s. 275; Sədiq, s. 442.

${ }^{122}$ Qəhrəmanov, C. II, s. 379; Araslı, C. II, s. 275; Sədiq, s. 435. perde var: perdedār; Araslı.

${ }^{123}$ Ayan, s. 819; Qəhrəmanov, C. II, s. 398; Arasli, C. II, s. 275; Sədiq, s. 445.

${ }^{124}$ Ayan, s. 818; Qəhrəmanov, C. II, s. 400; Araslı, C. II, s. 275; Sədiq, s. 445.

${ }^{125}$ Ayan, s. 819; Qəhrəmanov, C. II, s. 398; Arasli, C. II, s. 276; Sədiq, s. 446.

${ }_{126}$ Ayan, s. 819; Qəhrəmanov, C. III, s. 172; Arasl, C. II, s. 276; Sədiq, s. 446.

${ }^{127}$ Ayan, s. 819; Qəhrəmanov, C. II, s. 399; Arasli, C. II, s. 276; Sədiq, s. 444.

${ }_{128}$ Ayan, s. 819; Qəhrəmanov, C. II, s. 397; Qəhrəmanov, C. III, s. 172; Araslı, C. II, s. 267; Sədiq, s. 445.

${ }^{129}$ Köksal (2000), s. 191.

${ }^{130}$ Köksal (2000), s. 191.

${ }^{131}$ Ayan, s. 819; Qəhrəmanov, C. III, s. 171; Araslı, C. II, s. 275; Sədiq, s. 445. Bu mısra ile başlayan ve yukarıdaki kaynaklarda geçen tuyuğun diğer 3 mısraı farklıdır
} 
161. $213^{\mathrm{a}} \quad$ Fā vü żād u lāma düşdi göñlümüz ${ }^{132}$

162. $213^{\mathrm{b}}$ Şāh-1 sīm-endāma düşdi göñlümüz

163. $213^{\mathrm{b}} \quad$ Her hasis kim nefsini pāk eylemez ${ }^{133}$

164. 213 ${ }^{\mathrm{b}} \quad$ Biz ki 'ilm-i enbiyāda gelmişüz ${ }^{134}$

165. 213 $\quad$ Biz ki şems ile ḍuhāda gelmişüz

166. $213^{\mathrm{b}} \quad$ Emr-i Hak' dur çün cihāda gelmişüz

167. 213 ${ }^{\mathrm{b}}$ Biz ki bil od hāk șudan gelmişüz ${ }^{135}$

168. $213^{\mathrm{b}} \quad$ Biz ki varuz șanma yoḳdan gelmişüz

169. 214 $\quad$ Ebced og̉llyuz sebaḳdan gelmişüz

170. $214^{\mathrm{a}} \quad$ Biz ki derd-i 'aşḳa demsāz olmışuz

171. $214^{\mathrm{a}} \quad \overline{\mathrm{A}} \mathrm{b}$ u gilden biz ki pinhān olmışuz ${ }^{136}$

172. $214^{\mathrm{a}} \quad$ Biz ki Rūm içinde abdāl olmışuz

173. $214^{\mathrm{a}} \quad$ Biz ki dīdāruña 'āşı olmuşuz

174. $214^{\mathrm{a}} \quad$ Biz ki dirlik 'āleminde olmışuz

175. 214 ${ }^{\mathrm{a}} \quad$ Biz ki cām-1 'aşk-ile mest olmışuz

176. $214^{\mathrm{b}}$ Çün bu fānì 'ālem içre fāniyüz

177. $214^{\mathrm{b}} \quad$ Gerçi biz bu ālemüñ kallāşıyuz

178. 214 $\quad$ Biz ol abdāl-1 Rūm-1 bì-nevāyuz ${ }^{137}$

179. 214 $\quad$ Biz ki ol Fażlullāh'uñ leşkeriyüz

180. 214 ${ }^{\text {b }}$ Biz beni ādem ki ey dì hākiyüz ${ }^{138}$

181. 214 $\quad$ Bizi șūfi șanma șāfī rāhiyüz

182. 214 bażl-1 Haḳ'dan biz ki 'ālì-meşrebüz

183. 215 $\quad$ a Çünki faḳr u fāḳa ile rāḥatuz

184. 215 $\quad$ Biz ki ol bahrī vü bahrr-i vahdetüz

185. $215^{\mathrm{a}} \quad$ Ey țālib bāḳilik umma fenāsuz

186. 215 2 Çün Mesịh-i nuțk-ile hem-dem bizüz ${ }^{139}$

187. $215^{\mathrm{a}}$ Kirdigāruñ nuṭıına hāmil bizüz

188. $215^{\mathrm{a}} \quad$ Her nefes menzil-be-menzil göçerüz

189. 215 a Üç yüz altmış gün durur devrānımuz ${ }^{140}$

\footnotetext{
${ }^{132}$ Ayan, s. 818; Qəhrəmanov, C. III, s. 171; Arasl, C. II, s. 275; Sədiq, s. 445.

Qəhrəmanov, C. III'te 3. dize "Sünbülüñ tek dāma düșdi göñlümüz" yazma da "Dāne gördi dāma düșdi göñlümüz"

${ }^{133}$ Köksal (2000), s. 193.

${ }^{134}$ Köksal (2000), s. 191.

${ }^{135} \mathrm{Köksal} \mathrm{(2000),} \mathrm{s.} 192$.

${ }^{136}$ Köksal (2000), s. 193.

${ }^{137}$ Vezin aksiyor.

${ }^{138}$ Köksal (2000), s. 192.

${ }^{139}$ Köksal (2000), s. 192.

${ }^{140}$ Qəhrəmanov, C. II, s. 400; Araslı, C. II, s. 276; Sədiq, s. 445.
} 
190. 215 $\quad$ Gel beru gevher-şinās ol çün ayaz

191. $215^{\mathrm{b}} \quad$ Yidi kez yidi olur her yidimüz ${ }^{141}$

\section{Ḥarfü's-Sīn}

192. $215^{\mathrm{b}}$ Gel riżāsın iste Hakk $k^{\prime}$ un her nefes ${ }^{142}$

193. $215^{\text {bh }}$ Rezme ḳuru ma' rifetden el-g̀yyās ${ }^{143}$

194. $215^{\text {bh }} \quad$ Senlük ola ger senüñle bir nefes ${ }^{144}$

195. $215^{\mathrm{b}} \quad$ Devlet içün ḳoymayan meydāna baş

196. $215^{\mathrm{b}} \quad$ Yidi huaț̣̂ kim ḳlupdur Fażl fāş ${ }^{145}$

197. 215 'Indehu 'ilmü'l-kitāb ol māh imiş ${ }^{146}$

198. $215^{\mathrm{b}}$ Vechüñi bildüm ki vechu'llāh imiş ${ }^{147}$

199. $216^{\mathrm{a}} \quad$ Bil ki ādem maẓharı Allāh imiş

200. 216 ${ }^{\mathrm{a}} \quad$ Fażl[1] bilen sırr-1 Fażlu'llāh imiş

201. 216 $\quad$ Cümle eşyā Muṣhaf 1 āyāt imiş

202. $216^{\mathrm{a}} \quad \bar{A} \mathrm{demi}$ bu kā'ināta cān imiş ${ }^{148}$

203. $216^{\mathrm{a}}$ Yārumuñ gül tek yañağı ay imiş

204. 216 'Aş̣ sevdāsı 'aceb sevdā imiş ${ }^{149}$

205. 216 $\quad$ Ādemiye ma' rifet hoş tāc imiş

206. $216^{\mathrm{b}} \quad$ Ārıżuñ zülfüñ șabāḥ u şām imiş ${ }^{150}$

207. $216^{\mathrm{b}} \quad$ Bil bu ādem Haḳ'dan ulu ad imiş

208. $216^{\mathrm{b}} \quad$ Áşı̣uñ adı neden abdāl imiş ${ }^{151}$

209. 216 2 bünki vāḥidden sivā ìcād imiş

210. $\quad 216^{\mathrm{b}} \quad$ Áşı̣ u ma'şūk ḳadīmi yār imiş

211. 216 $\quad$ Çünki Selmān og̉l üstād er imiş ${ }^{152}$

212. $216^{\mathrm{b}}$ Dilberüñ la lüñden eşyā esrümiş ${ }^{153}$

\footnotetext{
${ }^{141}$ Qəhrəmanov, C. II, s. 399; Arasli, C. II, s. 276.

${ }^{142}$ Ayan, s. 820; Qəhrəmanov, C. II, s. 401; Arasl, C. II, s. 276; Sədiq, s. 446.

${ }^{143}$ Ayan, s. 804. "'̇1yās = غياث" kelimesi sin= w ile yazılmış.

${ }^{144}$ Ayan, s. 820.

145 Köksal (2000), s. 193.

${ }^{146}$ Qəhrəmanov, C. III, s. 173; Arasl, C. II, s. 276; Sədiq, s. 449; Köksal (2000), s. 190.

${ }^{147}$ Köksal (2000), s. 193.

${ }^{148}$ Köksal (2000), s. 193.

${ }^{149}$ Köksal (2000), s. 193.

${ }^{150}$ Qəhrəmanov, C. III, s. 174; Arasl, C. II, s. 277; Sədiq, s. 448.

${ }^{151}$ Ayan, s. 823; Qəhrəmanov, C. II, s. 610; Qəhrəmanov, C. III, s. 174; Arasl, C. II, s. 277; Sədiq, s. 448.

${ }^{152}$ Ayan, s. 823; Qəhrəmanov, C. II, s. 611; Qəhrəmanov, C. III, s. 175; Arasl, C. II, s. 277.

${ }^{153}$ Ayan, s. 822; Qəhrəmanov, C. II, s. 403; Arasl1, C. II, s. 278; Sədiq, s. 448.
} 


\begin{tabular}{|c|c|c|}
\hline 213. & $216^{\mathrm{bh}}$ & 'Ārifüñ adı niçün abdāl imiş ${ }^{154}$ \\
\hline 214. & $217^{\mathrm{a}}$ & Ehl-i “irfānuñ maḳāmı Ḳāf imiş ${ }^{155}$ \\
\hline 215. & $217^{\mathrm{a}}$ & Ey yüzüñ ol levh-ile mahfūz imiș ${ }^{156}$ \\
\hline 216. & $217^{a}$ & Cümle Hak'dur her ne kim mevcūd imiș 157 \\
\hline 217. & $217^{\mathrm{a}}$ & Ḳaşlaruñ kim ġāyet a'lā țāḳ-imiş 158 \\
\hline & $217^{\mathrm{a}}$ & Çünki hem evvel hem āhir yār imiş 159 \\
\hline & $217^{\mathrm{a}}$ & Muștafā medlūl u Ādem dāl imiş ${ }^{160}$ \\
\hline & $217^{\mathrm{a}}$ & Șūretüñ Ṭāhā ile $Y a \bar{s} \bar{i} n$ imiş ${ }^{161}$ \\
\hline & $217^{\mathrm{b}}$ & Sen yüzi māh-1 tamāmı buldum uş ${ }^{162}$ \\
\hline & $217^{\mathrm{b}}$ & 'Ālemi yüzüñ gülistān eylemiş ${ }^{163}$ \\
\hline & $217^{\mathrm{b}}$ & 'Aşş-ile ma'şūḳ u 'āşık bir imiş ${ }^{164}$ \\
\hline & $217^{\mathrm{b}}$ & Kün fekānuñ çünki aṣlı zaāt imiş ${ }^{165}$ \\
\hline
\end{tabular}

225. $217^{\mathrm{b}} \quad$ Çün ezelden ḳudret ile bì-galaț ${ }^{166}$

226. $217^{\mathrm{b}} \quad$ Vechinüñ levhindedür sì vü dü hat

\section{Harfü'l-Fä'}

227. $217^{\mathrm{b}}$ 'Aş̣ imiş sīmurg u 'āşı̣ kūh-1 Kāf 167

228. 218 $\quad$ Görmüşem sìmurğı ben der-kūh-1 Kāáf 168

229. 218 $\quad$ Sạaf-dil ol ṣufiyā sen urma lāf

230. 218a

\footnotetext{
${ }^{154}$ Ayan, s. 823; Qəhrəmanov, C. II, s. 403.

155 Ayan, s. 820; Qəhrəmanov, C. II, s. 405; Araslı, C. II, s. 278; Sədiq, s. 447. Bu tuyuğ Fenâyî Cennet Dîvâni’nda da vardır. Yıldız, s. 492-504; Aydın, s. 331-32.

156 Ayan, s. 821; Qəhrəmanov, C. II, s. 401; Arasl, C. II, s. 278.

157 Ayan, s. 821; Qəhrəmanov, C. II, s. 404; Araslı, C. II, s. 278; Sədiq, s. 447.

158 Ayan, s. 821; Qəhrəmanov, C. III, s. 173; Arasl, C. II, s. 277; Sədiq, s. 447.

${ }^{159}$ Ayan, s. 820; Qəhrəmanov, C. II, s. 405; Arasli, C. II, s. 278; Sədiq, s. 447.

${ }^{160}$ Ayan, s. 823; Qəhrəmanov, C. III, s. 173; Sədiq, s. 448.

${ }^{161}$ Ayan, s. 822; Qəhrəmanov, C. III, s. 174; Arasli, C. II, s. 277; Sədiq, s. 448

162 Ayan, s. 822; Qəhrəmanov, C. II, s. 404; Arasl, C. II, s. 278; Sədiq, s. 446.

163 Ayan, s. 820; Qəhrəmanov, C. II, s. 403; Arasl, C. II, s. 278; Sədiq, s. 446.

${ }^{164}$ Ayan, s. 820; Qəhrəmanov, C. II, s. 402; Arasli, C. II, s. 278; Sədiq, s. 447.

165 Ayan, s. 821; Qəhrəmanov, C. II, s. 402; Araslı, C. II, s. 279; Sədiq, s. 446.

${ }^{166}$ Ayan, s. 823; Arasl, C. II, s. 279; Sədiq, s. 449.

${ }^{167}$ Ayan, s. 824; Qəhrəmanov, C. II, s. 406; Araslı, C. II, s. 279; Sədiq, s. 449.

${ }^{168}$ Ayan, s. 824; Qəhromanov, C. III, s. 176.

${ }^{169}$ Farsça rubâi.
} 


\section{Harfï'l-Kāf}

231. 218 $\quad$ Ey Hak'a müştāk olan uş sende Hak ${ }^{170}$

232. 218 $\quad$ Fażl-1 Hak'dan çün hidāyet buldı Hak ${ }^{171}$

233. $218^{\text {a }}$ Gel ki gamdan cānumı yaḳdı firāk ${ }^{172}$

234. 218 $\quad$ ä̌n zümürrüd ḳıldı 'aynumı 'akịk ${ }^{173}$

235. $218^{\mathrm{b}} \quad$ Añlar olsañ cümle eşyādur sebak

236. $218^{\mathrm{b}} \quad$ Çün yüzinden zāhir oldı nūr-1 Hak

237. $218^{\mathrm{b}} \quad$ Her ki fażl-1 Hak'dan aldıysa sebak

238. $218^{\mathrm{b}} \quad$ Kudretinden her ne ki itdi mā-halak

239. $218^{\mathrm{b}} \quad$ Cemālüñ nūr-1 Yezdānī'dür el-ḥak

240. $\quad 218^{\mathrm{b}} \quad$ Bu nüh țāḳ ki gördüñ oldı erzak

241. $218^{\mathrm{b}} \quad$ Ey iki ḳaşuñ iki ‘ālemde tạk

242. 219 $\quad$ Bizüz ol pervāne kim pervāsı yok

243. $219^{\mathrm{a}} \quad$ Her kimüñ ki çehresinde zerdi yok

244. 219 $\quad$ Talmışşam şol baḥre kim pāyānı yoḳ ${ }^{174}$

\section{Harfü'l-Kāf}

245. 219a $\quad$ Ey ruhuñ 'aşḳında ser-gerdān felek ${ }^{175}$

246. 219a $\quad$ Ey güneş nūrı tecellidür yüzüñ ${ }^{176}$

247. $219^{\mathrm{a}}$

Ey ḩațuñ Huiżr āb-1 hạyvāndur sözüñ ${ }^{177}$

248. 219 $\quad$ Haş̧r u neşrüñ āfitābıdur yüzüñ ${ }^{178}$

249. 219a $\quad$ Hak 'ayān oldı gelüñ Hakkk'ı görüñ ${ }^{179}$

250. $219^{\text {b }} \quad$ Hak 'ayān oldı vü gitdi şirk ü şek ${ }^{180}$

251. 219 $\quad$ Dört gerek dört dört gerek üç dört gerek ${ }^{181}$

252. $219^{\text {b }} \quad$ Şem ${ }^{-}-i$ tevhìid-i hidāyetdür yüzün ${ }^{182}$

253. $\quad 219^{\mathrm{b}} \quad$ Ṣūret-i Ḥak'dan işāretdür yüzüñ ${ }^{183}$

\footnotetext{
170 Ayan, s. 824; Qəhrəmanov, C. II, s. 407; Araslı, C. II, s. 279; Sədiq, s. 449.

${ }^{171}$ Ayan, s. 824; Qəhrəmanov, C. II, s. 407; Araslı, C. II, s. 280; Sədiq, s. 449.

172 Ayan, s. 824; Qəhrəmanov, C. II, s. 408; Araslı, C. II, s. 280; Sədiq, s. 449.

${ }^{173}$ Ayan, s. 825; Qəhrəmanov, C. III, s. 177; Arasl, C. II, s. 280; Sədiq, s. 450.

${ }^{174} 206$ a da yer alan "yoh" redifli tuyuğun bazı kelimeleri değiştirilerek yeniden yazılmış.

175 Ayan, s. 826; Qəhrəmanov, C. II, s. 410; Arasli, C. II, s. 280; Sədiq, s. 450.

${ }^{176}$ Ayan, s. 828; Qəhrəmanov, C. II, s. 424; Arasli, C. II, s. 280.

${ }^{177}$ Ayan, s. 826; Qəhrəmanov, C. II, s. 421; Araslı, C. II, s. 280; Sədiq, s. 462.

${ }_{178}$ Ayan, s. 827; Qəhrəmanov, C. II, s. 422; Arasl, C. II, s. 280.

${ }^{179}$ Ayan, s. 826; Qəhrəmanov, C. II, s. 428; Araslı, C. II, s. 280; Sədiq, s. 462.

${ }^{180}$ Ayan, s. 825; Qəhrəmanov, C. II, s. 410; Arasli, C. II, s. 281; Sədiq, s. 450.

${ }^{181}$ Ayan, s. 826; Qphrəmanov, C. II, s. 409; Arasl, C. II, s. 282.

182 Ayan, s. 829; Qəhrəmanov, C. II, s. 424; Arasli, C. II, s. 281; Sədiq, s. 462.

183 Ayan, s. 827; Qəhrəmanov, C. II, s. 422; Arasli, C. II, s. 281; Sədiq, s. 462.
} 


\begin{tabular}{|c|c|c|}
\hline 4. & $219^{\mathrm{b}}$ & 'Āşıḳa ỉmān ile dīndür yüzüñ ${ }^{184}$ \\
\hline 5. & $219^{\mathrm{b}}$ & 'Āşıkuñ beytü'l-ḥarāmidur yüzüñ ${ }^{185}$ \\
\hline b. & $219^{\mathrm{b}}$ & 'Așḳ ehli bī-ser ü sāmān gerek ${ }^{186}$ \\
\hline 7. & $219^{\mathrm{b}}$ & Sî̀ vü dünüñ 'alā'imidür yüzüñ \\
\hline & $219^{\mathrm{b}}$ & Ḥamdüli'llāh yārümüñ gördüm yüzin ${ }^{187}$ \\
\hline & $220^{\mathrm{a}}$ & Fażl-1 Haḳk'ūñ cāvidānıdur yüzüñ ${ }^{188}$ \\
\hline & $220^{\mathrm{a}}$ & Kııle-i erbāb-1 tāa atdur yüzüñ ${ }^{189}$ \\
\hline & $220^{\mathrm{a}}$ & Mahşerüñ huurşsid ü māhıdur yüzüñ 190 \\
\hline & $220^{\mathrm{a}}$ & Maẓhar-1 esmā-yı küll oldı yüzüñ ${ }^{191}$ \\
\hline & $220^{\mathrm{a}}$ & $V e^{\prime} d \underline{d}-d \underline{d u h a ̄ n u n ̃ ~ a ̄ f i t a ̄ b ı d u r ~ y u ̈ z u ̈ n ̃ ~}{ }^{192}$ \\
\hline & $220^{\mathrm{a}}$ & $V e^{\prime} d$ - dụhānuñ āfitābıdur yüzüñ ${ }^{193}$ \\
\hline & $220^{\mathrm{a}}$ & Perçemi müşgin-i pür-çindür șaçuñ \\
\hline & $220^{\mathrm{a}}$ & Pertev-i nūr-1 tecellīiür yüzüñ ${ }^{194}$ \\
\hline & $220^{\mathrm{b}}$ & Ey elif kaddüñe lām oldı șaçuñ \\
\hline & $220^{\mathrm{b}}$ & Çün hüden li'l-muttakīin oldı șaçuñ \\
\hline & $220^{\mathrm{b}}$ & Firḳatinden yandı bu cān zülfüñüñ \\
\hline & $220^{\mathrm{b}}$ & Key mu'allā țāḳ olupdur ḳaşlaruñ \\
\hline & $220^{\mathrm{b}}$ & Bir 'aceb șāhib-ḳırāndur gözlerüñ ${ }^{195}$ \\
\hline & $220^{\mathrm{b}}$ & Fitne-engīz-i cihāndur gözlerüñ \\
\hline & $220^{\mathrm{b}}$ & Naḳdini mercāna virdi gözlerüñ 196 \\
\hline & $220^{\text {bh }}$ & Tīz ider cānuma ḩançer kirpügüñ ${ }^{197}$ \\
\hline & $220^{\text {bh }}$ & Baş ḳoyup her dem kemān-keş ḳaşlaruñ ${ }^{1}$ \\
\hline & $220^{\text {bh }}$ & Bir hadeng atduḳda yāre kirpigüñ 199 \\
\hline & $221^{\mathrm{a}}$ & Eyledi bağrumda uş yara gözüñ \\
\hline
\end{tabular}

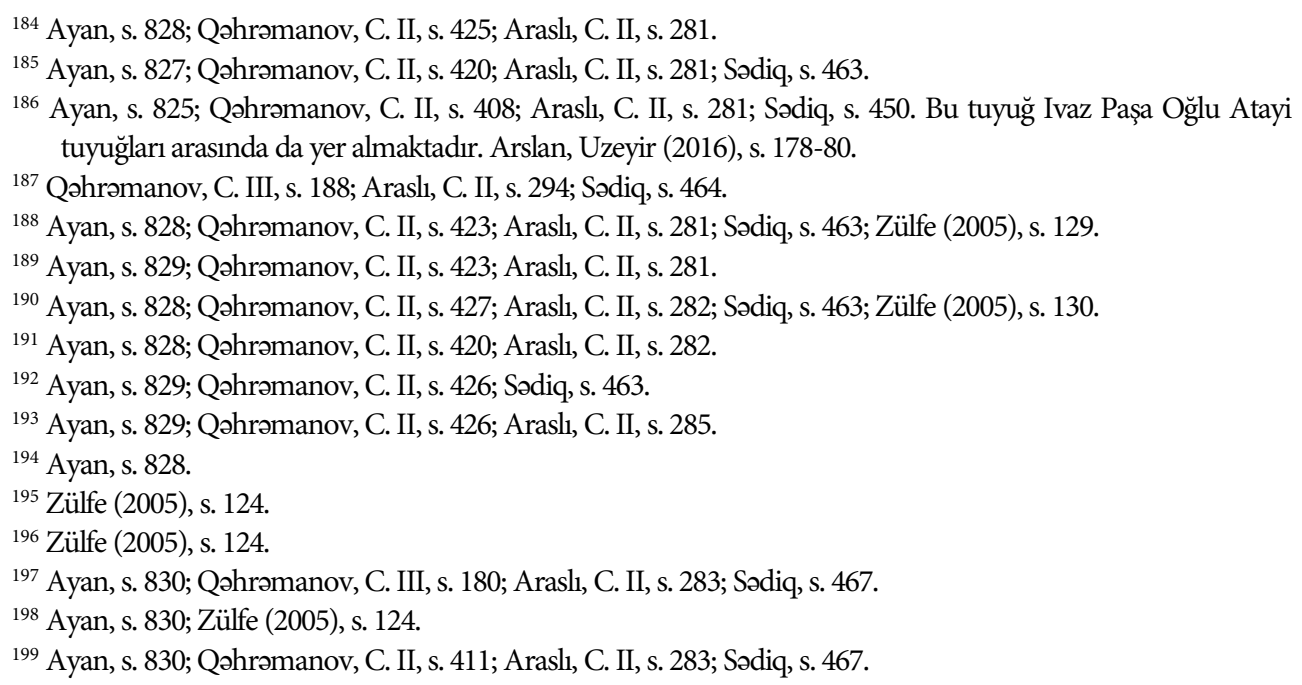


278. $221^{\text {a }} \quad$ Gör ne luṭf u ítibār eyler gözüñ

279. $221^{\mathrm{a}} \quad$ Bir 'aceb şirīin-kelām oldı lebüñ ${ }^{200}$

280. $221^{\text {a }} \quad$ Ey büt-i şirīin çü şekkerdür lebün ${ }^{201}$

281. $221^{\text {a }} \quad$ Selsebīle sāḳi oldı leblerüñ

282. 221 $1^{\text {a }}$ Cān gibi sırr-1 nihāndur ag̉uzuñuñ ${ }^{202}$

283. $221^{\text {ah }} \quad$ Siḥr-ile iletdi cādū gözlerüñ ${ }^{203}$

284. $221^{\text {ah }} \quad$ Siḥr-ile șayyād-1 cāndur gözlerüñ ${ }^{204}$

285. $221^{\text {b }}$ Ey lebi mercān güherdür dişlerüñ ${ }^{205}$

286. $221^{\text {b }}$ Ey șanem senüñ cevāhir dişlerüñ ${ }^{206}$

287. $221^{\text {b }}$ Bir 'aceb yākūt-1 nāṭkdur dilüñ ${ }^{207}$

288. $221^{\text {b }}$ Ṭūti-i cāna şekerdür sözlerüñ ${ }^{208}$

289. $221^{\text {bh }}$ Oldı çün āb-1 mu'allak gabg̉abuñ ${ }^{209}$

290. $221^{\text {b }}$ Dilberā sỉb-i zeḳandur gabgabuñ

291. $221^{\text {b }}$ 'Ālemi pür-nūr idüpdür șūretüñ ${ }^{210}$

292. $221^{\text {bh }} \quad$ Pertev-i nūr-1 Hudā'dur ruhlaruñ ${ }^{211}$

293. $221^{\text {bh }} \quad$ Kildı tende ur sarāy-1 ruhlaruñ ${ }^{212}$

294. $221^{\text {bh }} \quad$ Ehl-i dil bilür ki cāndur gabgabuñ ${ }^{213}$

295. 222 $\quad$ Añla kim fażl-1 Hudā'dur șūretüñ

296. $222^{a} \quad$ Gerçi kim sırr-1 nihāndur șūretüñ ${ }^{214}$

297. $222^{\mathrm{a}} \quad$ Fażlu'llāhu Raḥmāndur yüzüñ

298. 222 2 Āfitāb-1 mațla ${ }^{\mathrm{a}}-1$ cāndur yüzüñ

299. 222 $\quad$ Cennet-i 'Adn-i șırāt oldı yüzüñ

300. $222^{\mathrm{a}}$ Çeşme-i išnā 'aşerdür parmaguñ ${ }^{215}$

301. 222 $\quad$ Cān u dil olsun g̉ubār-1 pāyuñuñ ${ }^{216}$

\footnotetext{
200 Zülfe (2005), s. 126.

201 Ayan, s. 831; Qəhrəmanov, C. II, s. 413; Arasl1, C. II, s. 283; Sədiq, s. 464.

${ }^{202}$ Ayan, s. 831; Qəhrəmanov, C. III, s. 180; Araslı, C. II, s. 284; Sədiq, s. 464; Zülfe (2005), s. 127.

203 Ayan, s. 830; Qəhrəmanov, C. III, s. 179; Sədiq, s. 466.

${ }^{204}$ Ayan, s. 829; Qəhrəmanov, C. II, s. 419; Arasl, C. II, s. 283; Sədiq, s. 465.

${ }^{205}$ Ayan, s. 832; Qəhrəmanov, C. II, s. 413; Sədiq, s. 464; Zülfe (2005), s. 127.

206 Zülfe (2005), s. 127.

${ }^{207}$ Zülfe (2005), s. 128.

208 Ayan, s. 829; Qəhrəmanov, C. II, s. 416; Arasl, C. II, s. 283; Sədiq, s. 465; Zülfe (2005), s. 128.

${ }^{209}$ Ayan, s. 831; Qəhrəmanov, C. III, s. 181; Arasl, C. II, s. 284; Sədiq, s. 464; Zülfe (2005), s. 129.

${ }^{210}$ Zülfe (2005), s. 126.

${ }^{211}$ Ayan, s. 830; Qəhrəmanov, C. II, s. 426; Sədiq, s. 463; Zülfe (2005), s. 125.

212 Ayan, s. 830; Qəhrəmanov, C. II, s. 426; Sədiq, s. 463.

213 Ayan, s. 831; Qəhrəmanov, C. II, s. 412.

214 Zülfe (2005), s. 125.

${ }^{215}$ Zülfe (2005), s. 132.

${ }^{216}$ Ayan, s. 831; Zülfe (2005), s. 132.
} 


\begin{tabular}{|c|c|c|}
\hline 2 . & $222^{\text {ah }}$ & Nāfe-i Çīn ü Hatạā'dur beñlerüñ ${ }^{217}$ \\
\hline 303. & $222^{\text {ah }}$ & Müşg-i terden dāneler cān beñlerüñ ${ }^{218}$ \\
\hline 304. & $222^{\mathrm{b}}$ & Serverā serv-i revāndur kāmetüñ ${ }^{219}$ \\
\hline 5. & $222^{\mathrm{b}}$ & Hoş ḳıyāmet ḳadd-i bālādur boyuñ ${ }^{220}$ \\
\hline 306. & $222^{\mathrm{b}}$ & Āyet-i seb'u'l-meșānídür yüzüñ ${ }^{221}$ \\
\hline 307. & $222^{\mathrm{b}}$ & Ālemi ḳıldı münevver ay yüzüñ \\
\hline 308. & $222^{b}$ & Āyet-i seb'a'l-mesānīiür yüzüñ ${ }^{222}$ \\
\hline 309. & $222^{\mathrm{b}}$ & Żāyi' old1 renc hīc old1 emek 223 \\
\hline 310. & $222^{\mathrm{b}}$ & Ka'be'dür yüzüñ țavāf ider melek \\
\hline & $222^{\text {bh }}$ & Ālemüñ kavs-i hilālidür kaşuñ \\
\hline & $222^{\text {bh }}$ & Levh-i mahfūz-ile Kurāàn'dur yüzüñ \\
\hline 3. & $223^{\mathrm{a}}$ & Ṭariḳınca giderseñ şems-i dīnüñ ${ }^{224}$ \\
\hline 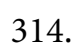 & $223^{\mathrm{a}}$ & Ușandum māl ü mülkinden cihāñuñ 225 \\
\hline 315. & $223^{a}$ & Dỉde'i-i 'irfānı aç bīdār iseñ ${ }^{226}$ \\
\hline 316. & $223^{a}$ & Her kime kim 'așkı hem-rāh eyledüñ \\
\hline 317. & $223^{a}$ & Yedi kez yigirmi sekizdür yüzüñ 227 \\
\hline & $223^{a}$ & Tālibā evvel kadem üç dört gerek 228 \\
\hline & $223^{a}$ & Perde götürdi yüzinden dilberüñ ${ }^{229}$ \\
\hline
\end{tabular}

\section{Harfü'l-Lām}

320. $223^{\text {b }} \quad$ İsm-i a'ẓam bilmeyen insān degül 230

321. $223^{\mathrm{b}} \quad$ Ol bilür Hakkk'1 ki yalancı degül ${ }^{231}$

322. $223^{\mathrm{b}} \quad$ İy cemālüñ bì-bedel hüsnüñ cemīl 232

\footnotetext{
217 Ayan, s. 831; Qəhrəmanov, C. III, s. 180; Arasl, C. II, s. 284; Sədiq, s. 466; Zülfe (2005), s. 125.

218 Ayan, s. 830; Qəhrəmanov, C. II, s. 418; Arasl1, C. II, s. 284; Sədiq, s. 466.

${ }^{219}$ Ayan, s. 831; Qəhrəmanov, C. III, s. 181; Arasl, C. II, s. 284; Sədiq, s. 464.

220 Zülfe (2005), s. 133.

${ }^{221}$ Ayan, s. 827; Qəhrəmanov, C. III, s. 178; Araslı, C. II, s. 282; Sədiq, s. 463; Zülfe (2005), s.130.

222 Ayan, s. 827; Qəhrəmanov, C. III, s. 178; Arasl, C. II, s. 282.

223 Ayan, s. 826.

224 "şemsü'd-dīnüñ" terkibi vezin gereği "șems-i dīn" yazıldı.

${ }^{225}$ Ayan, s. 832; Qəhrəmanov, C. III, s. 181; Arasl, C. II, s. 285. mefâîlün mefâîlün feûlün

${ }^{226}$ Ayan, s. 832; Qəhrəmanov, C. II, s. 428; Araslı, C. II, s. 285. Bu tuyuğ Ivaz Paşa Oğlu Atayi tuyuğları arasında da yer almaktadır. Arslan, Uzeyir (2016), s. 178-80.

227 Qəhrəmanov, C. II, s. 425.

${ }^{228}$ Qəhrəmanov, C. II, s. 409; Arasl, C. II, s. 285.

${ }^{229}$ Qəhrəmanov, C. II, s. 412; Arasl, C. II, s. 285.

${ }^{230}$ Ayan, s. 833; Qəhrəmanov, C. II, s. 430; Arasl, C. II, s. 286; Sədiq, s. 453.

231 Ayan, s. 833; Qəhrəmanov, C. II, s. 429; Arasl, C. II, s. 286; Sədiq, s. 453.

232 Ayan, s. 836; Qəhrəmanov, C. II, s. 429; Arasl1, C. II, s. 286; Sədiq, s. 451.
} 
323. $223^{\mathrm{b}} \quad$ Ey yüzüñden hụur u gilmān münfa ‘il ${ }^{233}$

324. $223^{\mathrm{b}} \quad$ Ey behiştden tāze gelmiş tāze gül ${ }^{234}$

325. $223^{\mathrm{b}} \quad$ Perdesüz ma 'būduñ gör 'ābid ol ${ }^{235}$

326. $223^{\mathrm{b}} \quad$ Ben otuz iki hurūfam lem-yezel ${ }^{236}$

327. 224 $\quad$ Hakk'a dog̀rı bak vü Ḥaḳk'1 doğrı bil ${ }^{237}$

328. 224 2 Çünki sensin her ne kim var ey göñül 238

329. 224 $\quad$ Huccetu'llāh oldı nuṭkuñ nāṭ̂k ol ${ }^{239}$

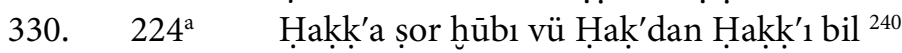

331. $224^{\mathrm{a}} \quad$ Rāzıku'r-erzākdur mer'aş degül ${ }^{241}$

332. 224 $4^{\mathrm{a}}$ Dünyenüñ ehlinden ușandı göñül ${ }^{242}$

333. 224 'Așk-imiş bāḳi vü hüünüñ $l \bar{a}-y e z a \bar{l} l^{243}$

334. 224 $\quad$ Kāmetüñden serv ü 'ar'ar münfa' il ${ }^{244}$

335. $224^{\mathrm{b}} \quad$ Geç ikilikden elif tek vāhiid ol ${ }^{245}$

336. 224 $\quad$ Gel ki sensüz bì-ḳarār oldı göñül ${ }^{246}$

337. 224 $\quad$ Gözlerüñ sevdāsina düşdi göñül ${ }^{247}$

338. $224^{\mathrm{b}} \quad$ Bir 'acāyib dilbere düşdi gönül ${ }^{248}$

339. $224^{\mathrm{b}} \quad$ Bì-vefã dünyādan uṣandı gönül 249

340. 224 $\quad$ Yüzüñi Hak $\quad 2$ dan çevirme Hakkk'ı bil ${ }^{250}$

341. 225 $\quad$ Mā-siva'llāh șūfiyā oldı hayāl

342. 225 2 Muṣtafă'nuñ şer ine sen 'āşı̣ ol

343. $225^{\mathrm{a}} \quad$ 'Ālem-i faḳrı fenāda fānì ol

344. $225^{\mathrm{a}} \quad$ Terk-i tecrid iklimine fāni ol

345. $225^{\mathrm{a}} \quad$ Bende-i feyyāż-1 fażl u Hualik ol

\footnotetext{
233 Ayan, s. 836; Qəhrəmanov, C. II, s. 435; Arasl, C. II, s. 286; Sədiq, s. 451.

${ }^{234}$ Ayan, s. 835; Qəhrəmanov, C. II, s. 430; Araslı, C. II, s. 286; Sədiq, s. 452.

235 Ayan, s. 835; Qəhrəmanov, C. II, s. 435; Araslı, C. II, s. 286; Sədiq, s. 451.

${ }^{236}$ Ayan, s. 836; Qəhrəmanov, C. II, s. 436; Araslı, C. II, s. 286; Sədiq, s. 450.

237 Ayan, s. 834; Qəhrəmanov, C. II, s. 611; Qəhrəmanov, C. III, s. 182; Arasl, C. II, s. 288; Sədiq, s. 453.

238 Ayan, s. 832; Qəhrəmanov, C. II, s. 433; Arasl1, C. II, s. 286; Sədiq, s. 452.

239 Ayan, s. 835; Qəhrəmanov, C. II, s. 439; Arasl1, C. II, s. 287; Sədiq, s. 452.

240 Ayan, s. 834; Qəhrəmanov, C. II, s. 438; Arasl, C. II, s. 287.

${ }^{241}$ Ayan, s. 834; Qəhrəmanov, C. II, s. 434; Arasl, C. II, s. 287.

242 Ayan, s. 832; Qəhrəmanov, C. II, s. 431.

${ }^{243}$ Ayan, s. 835; Qəhrəmanov, C. II, s. 436; Araslı C. II, s. 287; Sədiq, s. 451.

${ }^{244}$ Ayan, s. 836; Qəhrəmanov, C. II, s. 431; Arasl, C. II, s. 287; Sədiq, s. 451.

245 Ayan, s. 835; Qəhrəmanov, C. II, s. 434; Arasl, C. II, s. 287.

${ }^{246}$ Ayan, s. 832; Qəhrəmanov, C. II, s. 438; Arasl, C. II, s. 287; Sədiq, s. 452.

247 Ayan, s. 833; Qəhrəmanov, C. II, s. 432; Arasl, C. II, s. 287; Sədiq, s. 452.

248 Ayan, s. 833; Qəhrəmanov, C. III, s. 182; Araslı, C. II, s. 288; Sədiq, s. 452; Zülfe (2005), s. 134.

249 Ayan, s. 833; Qəhrəmanov, C. II, s. 437; Arasl, C. II, s. 288; Sədiq, s. 453.

250 Ayan, s. 834; Qəhrəmanov, C. II, s. 433; Arasl, C. II, s. 288.
} 
346. $225^{\mathrm{a}} \quad$ Şol kişi kim mest-i şehvet oldı ol

347. $225^{\mathrm{a}} \quad$ Her ki Fażl'uñ 'ilmine kāàil degül

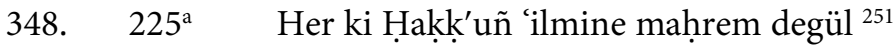

349. 225 ah $\quad$ Nuṭkuñ 1 Hak eyle Hak ${ }^{\prime}$ dan nāṭ̂ ol ol ${ }^{252}$

350. $225^{\mathrm{b}}$ Bu demi ḩoş gör ki yārā geçen dem dem degül ${ }^{253}$

351. 2225 $\quad$ Sendedür ol nūr-1 Allāh ey gönüül

352. $225^{\mathrm{b}} \quad$ Gözlerüñ alasına virdüm göñül

353. $225^{\mathrm{b}} \quad$ Hoḳka-i lü’lü'-i lālādur gönüül

354. 225 $\quad$ Noḳta-i esrār-1 esmādur göñül 254

355. 225 $\quad$ Ḥaț-1 reyhānına hayrāndur göñül

356. $225^{\mathrm{b}}$ Göñlüm eydür Hạkk'1 'ayān eylegil

357. 225 $\quad$ Cāhil-ile țutma iş ādem degül

358. $226^{\mathrm{a}} \quad$ Sözi gàayet fikr idüp derk eylegil

359. $226^{\mathrm{a}} \quad$ Vech-i ādem vech-i Rahmān oldı bil

360. 226 Çün şeyāṭin gavgāa ḳıldı ism-i a'ẓam yād ḳıl ${ }^{255}$

361. 226 $26^{\mathrm{a}}$ Kanı bir pāk ítiḳād u șāf-dil

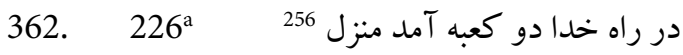

363. 226 $\quad$ Yahşıllıḳdur kim ider āzād ḳul

364. 226 $\quad$ Ma'rifetdür țālibā hayru'l-emel

365. $226^{\mathrm{b}} \quad$ Her kimüñ 'aḳlında olmaya halel

366. 226 2 Çünki Hakk'dur her ne var evvel ezel

367. $226^{\mathrm{b}} \quad$ Çün tecelli itdi Feyyāż̀-1 ezel

\section{Harfü'l-Mīm}

368. $226^{\mathrm{b}}$ Adımı Hak' dan Nesīmi yazaram ${ }^{257}$

369. $226^{\mathrm{b}} \quad$ Ol dem İsrāfil ü hem șūr olmuşam ${ }^{258}$

370. $226^{\mathrm{b}} \quad$ 'Aş̣ içinde gör ne hayrān olmışam ${ }^{259}$

371. $226^{\mathrm{b}} \quad$ Fażl-1 Haka'dan ben hidāyet bulmışam ${ }^{260}$

\footnotetext{
${ }^{251}$ Ayan, s. 834. Bu tuyuğ 225 kenarda kayıtlıdır.

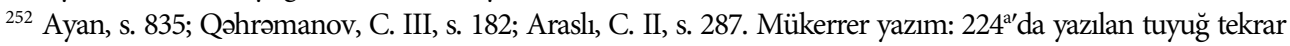
yazılmış.

253 fâilâtün fâilâtün fâilâtün fâilün

${ }^{254}$ Köksal (200), s. 194.

${ }^{255}$ fâilâtün fâilâtün fâilâtün fâilün

256 Farsça rubâi.

${ }^{257}$ Ayan, s. 840; Qəhrəmanov, C. II, s. 442; Arasl, C. II, s. 288; Sədiq, s. 454.

258 Ayan, s. 839; Qəhrəmanov, C. II, s. 441; Arasl, C. II, s. 289; Sədiq, s. 455.

${ }^{259}$ Ayan, s. 839; Qəhrəmanov, C. II, s. 612; Arasl, C. II, s. 291.

Qəhrəmanov neşrinde 3. misra eksik: 'İlm içinde bahr-i 'ummān olmışam, ŞR

${ }^{260}$ Ayan, s. 839; Qəhrəmanov, C. II, s. 442; Arasl1, C. II, s. 290; Sədiq, s. 456.
} 
372. 226 ${ }^{\text {bh }}$ Gel riżāsin iste Haḳk uñ sen müdām ${ }^{261}$

373. $227^{\mathrm{a}} \quad$ Ey cihān 'aş̣ ehline sensüz ḥarām ${ }^{262}$

374. $227^{\mathrm{a}} \quad$ Ey cemālüñ mazhar-1 zāât-1 ḳadīm ${ }^{263}$

375. $227^{\mathrm{a}} \quad$ Perde yüzinden götürdi Ḥaḳ tamām ${ }^{264}$

376. $227^{\mathrm{a}} \quad$ Ben ezelden mest ü hayrān gelmişem ${ }^{265}$

377. $227^{\mathrm{a}} \quad$ Ben vücūd-1 muṭlaḳam muṭlaḳ direm ${ }^{266}$

378. $227^{\mathrm{a}} \quad$ Ben ezelde aşk-ile pìr olmuşam ${ }^{267}$

379. 227 ${ }^{\mathrm{b}}$ Bulmuşam Haḳk'ı ene'l-ḥak söylerem ${ }^{268}$

380. $227^{\mathrm{b}} \quad$ Nār-1 'aşkuñ şu'lesinden yanmışam ${ }^{269}$

381. $227^{\mathrm{b}}$ Vechüñe cebbār-1 'ālemden selām ${ }^{270}$

382. $227^{\mathrm{b}} \quad$ Çün ezelden tã ebed bākỉ benem ${ }^{271}$

383. $227^{\mathrm{b}}$ Ravża-i Rı̣̣vān yüzüñdür ve's-selām ${ }^{272}$

384. $227^{\mathrm{b}} \quad$ Secde emrin dutmayan şeyțān-1 şūm ${ }^{273}$

385. $227^{\mathrm{b}} \quad$ Șūretüñ nakş̧ında ḥayrān olmışam ${ }^{274}$

386. $227^{\mathrm{b}} \quad$ Kibledür yüzüñ ḳara ḳaşuñ imām ${ }^{275}$

387. $227^{\mathrm{b}}$ Ben cihānda lā’ubāli dervişem ${ }^{276}$

388. $227^{\text {bh }} \quad$ Levḥ-ile Kur'ān yüzüñdür ve's-selām ${ }^{277}$

389. $228^{\text {a }} \quad$ Gördüm ol ayı vü bayram eyledüm ${ }^{278}$

390. $228^{\mathrm{a}}$ Lā-mekānuñ tah̆tına sulțān menem ${ }^{279}$

391. $228^{\mathrm{a}}$ Dünye hādis Allah'uñ zaătı ḳadīm ${ }^{280}$

\footnotetext{
261 Ayan, s. 837.

262 Ayan, s. 843; Qəhrəmanov, C. II, s. 447; Arasl, C. II, s. 289; Sədiq, s. 454.

263 Ayan, s. 844; Qəhrəmanov, C. II, s. 449; Arasl, C.II, s. 289.

${ }^{264}$ Ayan, s. 843; Arasl, C. II, s. 289.

265 Ayan, s. 838; Qəhrəmanov, C. II, s. 450; Araslı, C. II, s. 289; Sədiq, s. 457.

${ }^{266}$ Ayan, s. 840; Qəhrəmanov, C. II, s. 447; Araslı, C. II, s. 289; Sədiq, s. 457. direm: didüm, ŞR.

${ }^{267}$ Ayan, s. 839; Qəhrəmanov, C. II, s. 440; Arasl, C. II, s. 289; Sədiq, s. 455.

${ }^{268}$ Ayan, s. 837; Qəhrəmanov, C. II, s. 448; Arasl, C. II, s. 289; Sədiq, s. 456.

${ }^{269}$ Ayan, s. 840; Qəhrəmanov, C. III, s. 184; Arasl, C. II, s. 292; Sədiq, s. 456.

270 Ayan, s. 843; Qəhrəmanov, C. II, s. 612; Qəhrəmanov, C. III, s. 185; Arasl, C. II, s. 292; Sədiq, s. 454.

271 Ayan, s. 842; Qəhrəmanov, C. II, s. 451; Araslı, C. II, s. 290; Sədiq, s. 458.

272 Ayan, s. 838; Qəhrəmanov, C. II, s. 445; Arasl, C. II, s. 290; Sədiq, s. 456.

273 Ayan, s. 837; Qəhrəmanov, C. II, s. 449; Araslı, C. II, s. 290; Sədiq, s. 458. dutmayan: țutmadi; ŞR.

${ }^{274}$ Ayan, s. 839; Qəhrəmanov, C. II, s. 453; Arasli, C. II, s. 290; Sədiq, s. 455.

275 Ayan, s. 843; Qəhrəmanov, C. II, s. 443.

${ }^{276}$ Ayan, s. 840. Bu tuyuğ $227^{\mathrm{b}}$ kenarda kayıtlıdır.

277 Ayan, s. 838; Qəhrəmanov, C. II, s. 445; Araslı, C. II, s. 290; Sədiq, s. 454.

${ }^{278}$ Ayan, s. 841; Qəhrəmanov, C. II, s. 444; Arasl1, C. II, s. 290; Sədiq, s. 458.

${ }^{279}$ Ayan, s. 842; Qəhrəmanov, C. II, s. 452; Arasl, C. II, s. 290; Sədiq, s. 457.

${ }^{280}$ Ayan, s. 844.
} 
392. $228^{\text {a }}$ Dünyede 'ömrümi gördüm bir țutam ${ }^{281}$

393. $228^{\mathrm{a}} \quad$ Mestem ol meyden ki maḩmūr olmazam ${ }^{282}$

394. 228 $8^{\text {a }}$ Mușhaf'uñ harfi vü evrāḳı benem ${ }^{283}$

395. $228^{\text {a }}$ Vechümi Allāh'a teslim itmişem ${ }^{284}$

396. $228^{\mathrm{b}} \quad$ Vaḥdetüñ şehrinde seyrān eylerem ${ }^{285}$

397. $228^{\mathrm{b}} \quad$ Her neye kim bakaram Hak bakaram ${ }^{286}$

398. $228^{\text {b }} \quad$ Yāra her sā at selām olsun selām ${ }^{287}$

399. $228^{\mathrm{b}} \quad$ Menzil-i Maḥmūd imiş 'ālì-maḳām ${ }^{288}$

400. $228^{\mathrm{b}} \quad$ Nāgehān būstāna girdüm șubḥ-dem ${ }^{289}$

401. $228^{\mathrm{b}} \quad \mathrm{H}^{\mathrm{v} a ̄ c e}-\mathrm{i}$ dünyā vü dīn kuṭbı imām

402. $228^{\mathrm{b}} \quad$ Min-ledün 'ilminden işit bir kelām

403. $229^{\mathrm{a}} \quad$ Ögredenler diline 'ādì kelām

404. 229 $\quad$ Her nefes ol dilbere ben hādimem

405. 229 $\quad$ Dilberüñ yolına cānı terk idem ${ }^{290}$

406. 229 $\quad$ Gözlerüñ esrārını fāş eyledüm ${ }^{291}$

407. 229a $\quad$ Her sehergeh derd-ile āh eylerem ${ }^{292}$

408. 229 $\quad$ Her zamān kim derd-ile yā hū direm

409. 229a Bülbül oldum bir 'acāyib öterem ${ }^{293}$

410. 2229

411. 229 $\quad$ Vaḥdetüñ bahrinde her dem yüzerem ${ }^{295}$

412. 229 $\quad$ Hak benem Ḥak bendedür haḳdur sözüm ${ }^{296}$

413. 229 2 Maẓhar-1 Yezdān'a dūş oldı gözüm ${ }^{297}$

414. 229 $\quad$ Ben hakịikat maẓharı żāt olmuşam

\footnotetext{
281 Ayan, s. 842.

282 Ayan, s. 840; Qəhrəmanov, C. II, s. 443; Arasl, C. II, s. 291; Sədiq, s. 455.

${ }^{283}$ Ayan, s. 842; Qəhrəmanov, C. II, s. 446; Arasl1, C. II, s. 291; Sədiq, s. 457.

${ }^{284}$ Ayan, s. 838; Qəhrəmanov, C. II, s. 452; Arasl, C. II, s. 291; Sədiq, s. 457.

285 Ayan, s. 841; Qəhrəmanov, C. II, s. 444; Arasl, C. II, s. 291; Sədiq, s. 457.

286 Ayan, s. 837; Qəhrəmanov, C. II, s. 446; Arasl, C. II, s. 291; Sədiq, s. 455.

${ }^{287}$ Ayan, s. 838; Qəhrəmanov, C. II, s. 448; Arasl, C. II, s. 293; Sədiq, s. 453.

288 Ayan, s. 837; Qəhrəmanov, C. II, s. 451; Arasl, C. II, s. 292; Sədiq, s. 454.

${ }^{289}$ Ayan, s. 844; Qəhrəmanov, C. III, s. 184; Arasl, C. II, s. 291; Sədiq, s. 453

${ }^{290}$ Arasl, C. II, s. 291; Sədiq, s. 456.

${ }^{291}$ Ayan, s. 841; Qəhrəmanov, C. II, s. 440; Arasl, C. II, s. 292; Sədiq, s. 456.

292 Köksal (2000), s. 195.

293 Ayan, s. 841.

${ }^{294}$ Farsça rubâi.

295 Ayan, s. 841; Qəhrəmanov, C. II, s. 439.

${ }^{296}$ Köksal (2000), s. 195.

${ }^{297}$ Köksal (2000), s. 195.
} 
415. $229^{\mathrm{b}} \quad$ Alnuñuñ ayına ḥayrān olmışam 298

416. 229 $\quad$ Perdelü bir dilbere zār olmuşam

417. $229^{\text {bh }} \quad$ Söziñi cāndan sevenler ey himām ${ }^{299}$

418. 229 Görmeyince seni ey cān gözlerüm

419. $230^{\mathrm{a}}$ Ben ki ferdā günin imrūz itmişem

420. 230 $\quad$ Tā temennā-yı viṣālüñ itmişem

421. 230 $\quad 230^{\mathrm{a}} \quad$ Fürḳatüñden gör ne hāle dönmüșem

422. 230 $\quad$ Göñlümi ol yüze hayrān ḳılmışam

423. $230^{\mathrm{a}} \quad$ Benüm vaḥdetdedür yār-ile işüm

424. 230a $300 \quad 300$

425. 230 $\quad$ Șūretüñoür vech-i Raḥmān ey hakīim

426. 230 $\quad$ Var yüzüñde bist ü yek harf-i kadīm ${ }^{301}$

427. $230^{\mathrm{a}} \quad$ Șūretüñdür bismi'llāhi'r-rahmāni'r-rahìm ${ }^{302}$

428. $230^{\text {b }}$ Vech-i ādem oldı ol ism-i 'azịm ${ }^{303}$

429. $230^{\mathrm{b}} \quad$ Vech-i ādemdür șırātu'l-müstakim ${ }^{304}$

430. $230^{\mathrm{b}} \quad \bar{A} d e m^{\prime}$ üñ vechidür ol vech-i Kerìm ${ }^{305}$

431. 230 ${ }^{\mathrm{b}} \quad$ Çünki irdi bād-ilen būy-1 nesīm ${ }^{306}$

432. $230^{\mathrm{b}}$ Ḥaḳk sende ḳoma kim dād eyleyem ${ }^{307}$

433. $230^{\mathrm{b}} \quad$ Gice mi var șubha dek āh itmeyem

434. $230^{\mathrm{b}} \quad$ Leblerün şerbetini nūş eyledüm

435. $230^{\text {bh }} \quad$ Fażl-1 bism'illāhi'r-rahmāni'r-rahìm ${ }^{308}$

436. $231^{\text {a }} \quad$ Āyet-i Raḥmān yüzüñdür ve's-selām ${ }^{309}$

437. 231 $\quad$ Ka $\quad$ a'be-i makṣūd yüzüñoür ve's-selām ${ }^{310}$

\section{Harfü'n-Nūn}

438. $\quad 231^{\mathrm{a}} \quad$ Olmadı çün Ḥaḳk'a iḳrāruñ bütün ${ }^{311}$

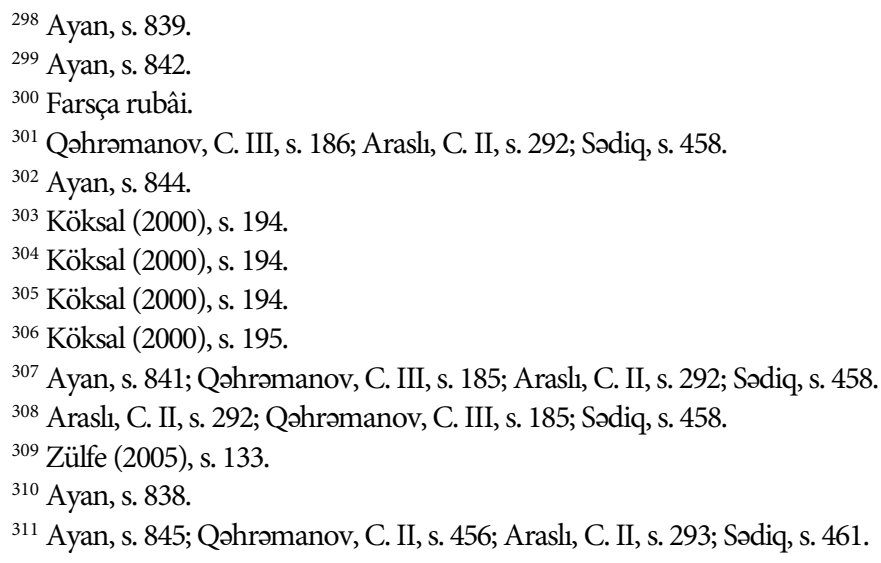




\begin{tabular}{|c|c|c|}
\hline 439. & $231^{\mathrm{a}}$ & Ey özüñden bī-ḩaber gaāil uyan ${ }^{312}$ \\
\hline 440. & $231^{\mathrm{a}}$ & Ey țolu senden cihān senden cihān ${ }^{313}$ \\
\hline 441. & $231^{\mathrm{a}}$ & İy yüzüñ bāg̀ında sünbül lāle-çīn ${ }^{314}$ \\
\hline 442. & $231^{\mathrm{a}}$ & Perdeden māh-1 tamām oldı 'ayān ${ }^{315}$ \\
\hline 443. & $231^{\mathrm{a}}$ & Enbiyānuñ șavm u 'iydı ey fülān ${ }^{316}$ \\
\hline 444. & $231^{\mathrm{b}}$ & Ger dilerseñ Hūāikk'i itmek 'ayān 317 \\
\hline 445. & $231^{b}$ & Haḳ'dan āgāh ol ki Haḳ'dur cāvidān ${ }^{318}$ \\
\hline 44 & $231^{b}$ & Cānumı yandurdı şevḳuñ ḳandasan 319 \\
\hline 447. & $231^{b}$ & Mag̉rib ü maşrıḳda Haḳ̆'dur söyleyen ${ }^{320}$ \\
\hline 448. & $231^{b}$ & Haḳ tecelli eyledi Mūsā içün ${ }^{321}$ \\
\hline 449 . & $231^{b}$ & Haḳ Te ālā perdesüz oldı 'ayān ${ }^{322}$ \\
\hline 450. & $231^{b}$ & Ger Haḳ'ı sen tanımışsan bi்-gümān ${ }^{323}$ \\
\hline 451. & $231^{\text {bh }}$ & Çünki virdüñ göñlüñi bir yāre sen ${ }^{324}$ \\
\hline 452. & $231^{\text {bh }}$ & Ma'rifet kesb itmedüñ sen fānisen ${ }^{325}$ \\
\hline 453. & $232^{\mathrm{a}}$ & Ger sen isterseñ Haḳ' ${ }^{\prime}$ bilmek yaḳin ${ }^{326}$ \\
\hline 454. & $232^{\mathrm{a}}$ & Cok tavā'if geldi geçdi çok zamān 327 \\
\hline 455. & $232^{\mathrm{a}}$ & Ben vücūd-1 muṭlaḳ oldum bī-gümān \\
\hline 45 & $232^{\mathrm{a}}$ & Dir ḳıyāmet ḳaddini gören revān \\
\hline 45 & $232^{\mathrm{a}}$ & Ey boyu serv-i hırāmān ḳandasan \\
\hline 45 & $232^{\mathrm{a}}$ & Server-i sulțān-1 'ālemsen bugün \\
\hline 459. & $232^{\mathrm{a}}$ & Va‘de-i rūz-ı ḳyām oldı bugün \\
\hline 460. & $232^{\text {ah }}$ & Şehā bir bì-bașiret ādemem ben ${ }^{328}$ \\
\hline
\end{tabular}

\footnotetext{
312 Ayan, s. 846; Qəhrəmanov, C. II, s. 458; Araslı, C. II, s. 293; Sədiq, s. 461.

${ }^{313}$ Ayan, s. 847; Qəhrəmanov, C. II, s. 455; Araslı, C. II, s. 293; Sədiq, s. 460.

${ }^{314}$ Ayan, s. 844; Qəhrəmanov, C. II, s. 455; Arasl, C. II, s. 293; Sədiq, s. 464.

${ }^{315}$ Ayan, s. 843; 845; Qəhrəmanov, C. II, s. 453; Arasl, C. II, s. 293; Sədiq, s. 460.

${ }^{316}$ Ayan, s. 847. Bu tuyuğ $231^{\mathrm{a}}$ kenarda kayıtlıdır.

317 Ayan, s. 846; Qəhrəmanov, C. III, s. 187; Arasl, C. II, s. 295; Sədiq, s. 459.

${ }^{318}$ Ayan, s. 847; Qəhrəmanov, C. III, s. 186; Araslı, C. II, s. 295; Sədiq, s. 460

319 Ayan, s. 845; Qəhrəmanov, C. II, s. 457; Araslı, C. II, s. 293; Sədiq, s. 460.

${ }^{320}$ Ayan, s. 847; Qəhrəmanov, C. II, s. 454; Araslı, C. II, s. 293; Sədiq, s. 467.

${ }^{321}$ Ayan, s. 845; Qəhrəmanov, C. II, s. 458; Araslı, C. II, s. 294; Sədiq, s. 461.

${ }^{322}$ Ayan, s. 845; Qəhrəmanov, C. II, s. 456; Arasl, C. II, s. 294; Arasl, C. II, s. 295; Sədiq, s. 459.

Bu tuyuğ Araslı neşrinde sadece üç kelime farkıyla hem 294. sayfada hem de 295. sayfada yazılıdır.

323 Ayan, s. 848; Qəhrəmanov, C. II, s. 454; Arasli, C. II, s. 294; Sədiq, s. 459.

${ }^{324}$ Ayan, s. 848.

${ }^{325}$ Qəhrəmanov, C. III, s. 190; Arasl, C. II, s. 296; Sədiq, s. 460.

${ }^{326}$ Ayan, s. 847; Qəhrəmanov, C. II, s. 457; Arasli, C. II, s. 294; Sədiq, s. 466.

${ }^{327}$ Ayan, s. 848; Qəhrəmanov, C. III, s. 187; Arasl, C. II, s. 295; Sədiq, s. 459.

${ }^{328}$ Ayan, s. 846. mefầllün mefầllün feûlün
} 
461. 232 $2^{\text {ah }}$ Lā-mekāna rāst iletdüm rāh ben ${ }^{329}$

462. 232 ahe Akıdalı gözlerümden yaşı ben

463. $232^{\mathrm{b}} \quad$ Fażl-1 feyyāż-1 ezelden lā-yezāli Şems-idīn ${ }^{330}$

464. $232^{\mathrm{b}} \quad$ Bu cihān cānınuñ ol yüzi żıyāsı Șems-i dīn ${ }^{331}$

465. 232 $\quad$ Genc-i ehl-i h hāācegānuñ agnniyās Șems-i dīn ${ }^{332}$

466. 232 $\quad$ Șuffa-i ehl-i șafānuñ ol șafāsı Şems-i dīn ${ }^{333}$

467. 232 $2^{\mathrm{b}}$ Cānumı yandurdı şāhā iştiyāḳı Şems-i dīn ${ }^{334}$

468. $232^{\mathrm{b}} \quad$ Kend'özin șūretde Hạ ḳılmış güzin

469. $232^{\mathrm{b}} \quad$ Her ki tanıdı o nefsi hilkatin

470. $233^{\mathrm{a}} \quad$ Haşr-i maksṣūd-ı halāyıl yā emīn ${ }^{335}$

471. $233^{\mathrm{a}} \quad$ Münezzehdür yeri gögi yaradan

\section{Harfü'l-Vāv}

472. $233^{\mathrm{a}} \quad$ Bunca hāy hū vü bunca hāy u hū 336

\section{Harfü'l-Hā}

473. $233^{a} \quad$ İy ḳamer zülfün şebinde rū-siyāh ${ }^{337}$

474. $233^{\text {a }} \quad$ Cānumuñ la li meyidür cām ile ${ }^{338}$

475. 233 $233^{\text {a }}$ Düşmüşem mestāne 'aynuñ āline 339

476. $233^{\mathrm{a}} \quad$ Secde eyler yüzüñe mihr-ile māh ${ }^{340}$

477. $233^{\text {ah }} \quad$ Ey hayāsı görklü vü yüzi șulu ${ }^{341}$

478. 233 $\quad$ Fażl Rabb-1 zü̈l-celāl oldı bize ${ }^{342}$

479. $233^{\text {b }} \quad$ Mescid ü meyhāne bir oldı bize ${ }^{343}$

\footnotetext{
${ }^{329}$ Ayan, s. 846.

${ }^{330}$ Nazm; fâilâtün fâilâtün fâilâtün fâilün. Kelime nüshada "şemsü'd-dīn" şeklinde yazıldı̆̆ı halde metnin Latin harflerine aktarımında vezin gereği “şems-i dīn”şeklinde yazıldı.

${ }^{331}$ Nazm; fâilâtün fâilâtün fâilâtün fâilün

${ }^{332}$ Nazm; fâilâtün fâilâtün fâilâtün fâilün

${ }^{333}$ Nazm; fâilâtün fâilâtün fâilâtün fâilün

${ }^{334}$ Nazm; fâilâtün fâilâtün fâilâtün fâilün

${ }^{335}$ Ayan, s. 846; Qəhrəmanov, C. III, s. 189; Arasl, C. II, s. 294.

336 Ayan, s. 848; Qəhrəmanov, C. II, s. 459; Qəhrəmanov, C. III, s. 192; Arasl1, C. II, s. 296.

337 Ayan, s. 848; Qəhrəmanov, C. II, s. 469; Araslı, C. II, s. 297; Sədiq, s. 469.

338 Ayan, s. 852; Qəhrəmanov, C. II, s. 465; Arasl, C. II, s. 298; Sədiq, s. 470.

339 Ayan, s. 850; Qəhrəmanov, C. II, s. 467; Arasl, C. II, s. 298; Sədiq, s. 430.

${ }^{340}$ Ayan, s. 849; Qəhrəmanov, C. II, s. 464; Arasl, C. II, s. 298; Sədiq, s. 469.

${ }^{341}$ Ayan, s. 848.

342 Ayan, s. 852; Qəhrəmanov, C. II, s. 465; Araslı, C. II, s. 298; Sədiq, s. 470.

${ }^{343}$ Ayan, s. 852; Qəhrəmanov, C. II, s. 466; Araslı, C. II, s. 298; Sədiq, s. 470.
} 


\begin{tabular}{|c|c|c|}
\hline 480. & $233^{\mathrm{b}}$ & Virmemek dil dilberüñ gīsūsına ${ }^{344}$ \\
\hline & $233^{\mathrm{b}}$ & Cān fedā cānlar fedā enfāsına ${ }^{345}$ \\
\hline 482. & $233^{\mathrm{b}}$ & Hak'dan özge sen saña yār eyleme ${ }^{346}$ \\
\hline 483. & $233^{\mathrm{b}}$ & Cāndadur yār iy göñül yār isteme ${ }^{347}$ \\
\hline & $233^{\mathrm{b}}$ & Hakk'1 bāṭl sanma Hak yokdur dime ${ }^{348}$ \\
\hline & $233^{\mathrm{b}}$ & Gülşen oldur ki güli hiç șolmaya \\
\hline & $234^{\mathrm{a}}$ & Kim ki irdi șūretüñ mánīsine ${ }^{349}$ \\
\hline & $234^{\mathrm{a}}$ & Menba'-1 ìmān didiler șaçuña \\
\hline & $234^{\mathrm{a}}$ & Ṭolaşalu dil perişsān zülfüñe 350 \\
\hline & $234^{\mathrm{a}}$ & Oldı çün devlet müyesser başuña ${ }^{351}$ \\
\hline & $234^{\mathrm{a}}$ & Çün ināyet oldı lāyık başuña \\
\hline 49 & $234^{\mathrm{a}}$ & Ey ḳamer māh-ı münevver alnuña \\
\hline 19 & $234^{\mathrm{a}}$ & Şükr ider māh-1 münevver alnuña ${ }^{352}$ \\
\hline 49 & $234^{\mathrm{a}}$ & Egri vü uğrı vü fettān ḳaşuña ${ }^{353}$ \\
\hline & $234^{\mathrm{a}}$ & Cān u göñül tolaşalı zülfüñe \\
\hline & $234^{\mathrm{b}}$ & Bir güzellik virdi ol Ḥaḳ yüziñe \\
\hline & $234^{\mathrm{b}}$ & Ḩām gümişdür dir her aḥmaḳ burnuña 354 \\
\hline & $234^{\mathrm{b}}$ & İrmedi şol āb-1 hayvān la'lüñe 355 \\
\hline 49 & $234^{\mathrm{b}}$ & Bir 'acāyib ṣuṣadı cān la'lüñe \\
\hline 49 & $234^{\mathrm{b}}$ & Ṭag̀ıdup ol zülf-i hāāi boynuña 356 \\
\hline 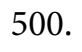 & $234^{\mathrm{b}}$ & Gerçi şā̄ir āb eydür boynuña \\
\hline & $234^{\mathrm{b}}$ & Kim didi kim sìm-i hāmdur gögsüñe 357 \\
\hline & $235^{a}$ & İncedür mūdan disem mū bilüñe 358 \\
\hline
\end{tabular}

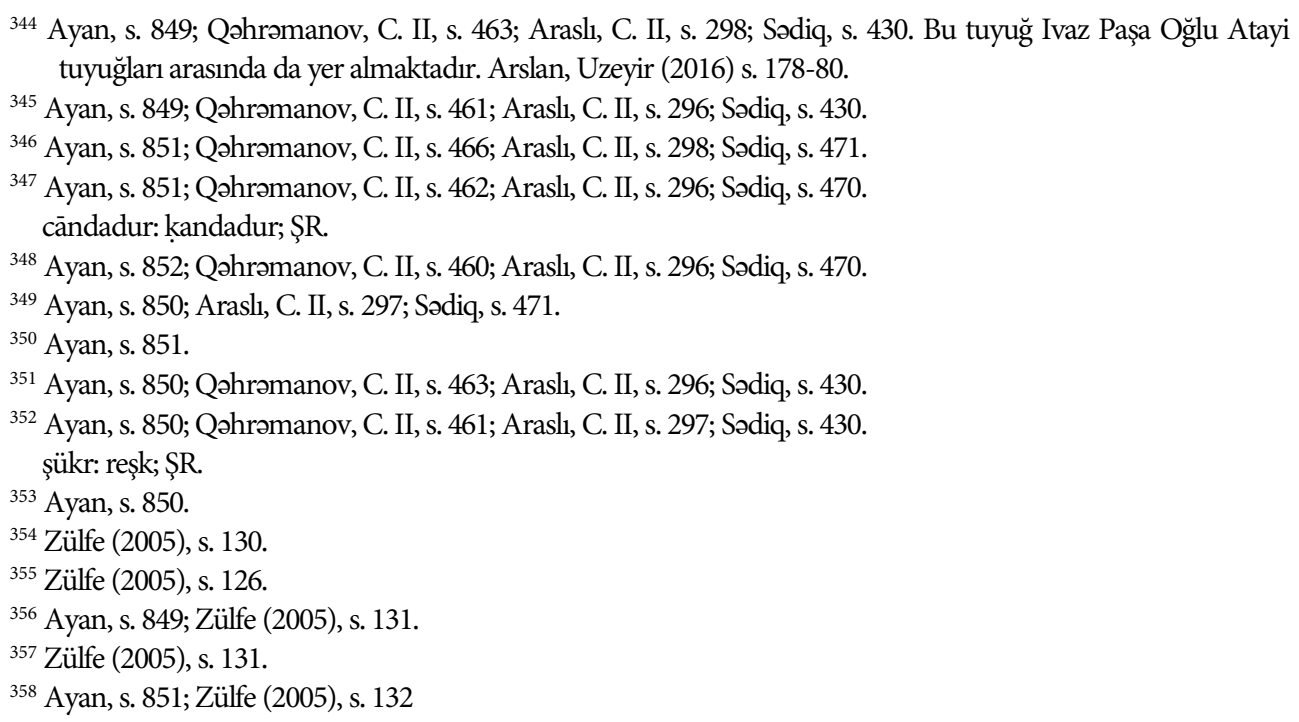


503. $235^{\mathrm{a}} \quad$ Kim elifdür didi kim hā boyuña

504. 235' 'Ayn u lām u yā durur göñlümde şāh

505. 235 $\quad$ Çünki oldı hüsnüñe nūr-1 İlāh

506. $235^{\mathrm{a}} \quad$ Áşıkuñur yer ü gök şems-ile māh ${ }^{359}$

507. 235 2 a Sūretüñ beytü'l-harām oldı bize

508. $\quad 235^{\mathrm{a}} \quad$ Ṣūfinüñ destārı bizde bir pile

509. $235^{\text {ah }}$ 'Aşk-ile keçe harīir oldı bize ${ }^{360}$

510. 235 $\quad$ Mím elif üç 'ayn ile gördüm bile ${ }^{361}$

511. 235 $\quad$ Kaş u kirpük yidi olur șaç-ile ${ }^{362}$

512. $235^{\mathrm{b}} \quad$ Bülbül-i şūrīdeyem gülzāruña

513. $235^{\mathrm{b}} \quad$ Şeş cihetden irmişem makṣūduma

514. 235 $\quad$ Ey gönül her yaña pervāz eyleme ${ }^{363}$

515. 235 $\quad$ Yahşı ol ey dil yamana beñzeme

516. 235 2 büşdi göñlüm ğamze-i cādūsına

517. 236 ${ }^{\mathrm{a}}$ Şems-i maǵrib tog dı 'ālem üstine

518. 236 ${ }^{\mathrm{a}}$ Düşmüşem mestāne 'aynuñ āline

519. 236 Hak hidāyet eyledi luṭ ehline

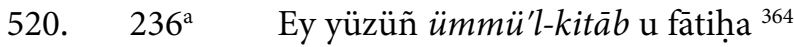

521. 236 ${ }^{\mathrm{a}}$ Bāg̀-1 cennet hūr-1 Rıḍvān fātiha

522. 236 ${ }^{\mathrm{a}}$ Bize cūdı ḳldı Sübhān fātiha

523. 236 $6^{\mathrm{a}} \quad \bar{A} \mathrm{dem}^{\prime}$ i bir oldı insān fātihạa

524. $236^{\mathrm{b}}$ Rūy-1 huațuñ māh-1 tābān fātiḥa

525. $236^{\mathrm{b}} \quad$ Ṣūretüñdür vech-i Rahmān fātiḥa

526. $236^{\mathrm{b}} \quad$ Yazdı alnuñ üzre Yezdān fātiḥa

527. $236^{\mathrm{b}} \quad \bar{A} y e t-i$ seb $u^{\prime} l-m e s a ̄ n \bar{i}$ fātiha

528. $236^{\mathrm{b}} \quad$ Gün yüzüñür cāvidāni fātiha

529. $236^{\text {b }}$ Olduğıçün vech-i Raḥmān fātiha

530. $236^{\text {b }} \quad$ Vech-i ādem oldı ey cān fātiḥa

\section{Harf-i Lām-elif}

531. $237^{\mathrm{a}} \quad$ Ben kebūter görmedüm kim bāz ola ${ }^{365}$

\footnotetext{
${ }^{359}$ Qəhrəmanov, C. III, s. 190; Arasli, C. II, s. 297; Sədiq, s. 469.

${ }^{360}$ Ayan, s. 852.

${ }^{361}$ Qəhrəmanov, C. III, s. 191; Araslı, C. II, s. 297. Qəhrəmanov neşrinde bazı kelime farklılıkları vardır.

362 Qəhrəmanov, C. II, s. 460; Arasl, C. II, s. 296.

363 Ayan, s. 851; Qəhrəmanov, C. II, s. 462; Arasli, C. II, s. 296.

${ }^{364}$ Ayan, s. 849; Qəhrəmanov, C. II, s. 464; Arasl, C. II, s. 298; Sədiq, s. 470.

365 Qəhrəmanov, C. III, s. 192; Arasl, C. II, s. 297; Sədiq, s. 429.
} 


\section{Harfü'l-Yā}

532. $237^{\mathrm{a}} \quad$ Ey saçuñ būyı Mesīhāànuñ demi 360

533. $237^{\mathrm{a}}$ Ey kamer tal' atlu şems-i hāveri ${ }^{367}$

534. $237^{\mathrm{a}}$

Ey ḳaşuñla kirpigüñ zülfüñ yidi ${ }^{368}$

535. $237^{\mathrm{a}}$ Hak ṣıyām ayı[n] bize 'iyd eyledi ${ }^{369}$

536. $237^{\mathrm{a}}$ Hak didi kim yer yidi vü gök yidi ${ }^{370}$

537. $237^{\mathrm{a}}$ Ey lebüñ vașlı hayāt-1 sermedi ${ }^{371}$

538. $237^{\text {ah }}$ Menba'-1 cūd u 'ațā bil ādemi

539. $237^{\mathrm{b}}$

Gözleri pür-ḩāba virdüm göñlümi ${ }^{372}$

540. $237^{\mathrm{b}}$

Zülf-i 'anber-sāya virdüm göñlümi ${ }^{373}$

541. $237^{\mathrm{b}}$

Şol büt-i ra'nāya virdüm göñlümi ${ }^{374}$

542. $237^{\mathrm{b}}$

Nāgehān bir aya virdüm göñlümi ${ }^{375}$

543. $237^{\mathrm{b}}$

Șūretüñ Muṣḥaf'dur ey cān pāresi ${ }^{376}$

544. $237^{\mathrm{b}}$

Ma rifet ehline Hak bỉnā didi ${ }^{377}$

545. $237^{\mathrm{b}}$

Ey yüzüñ ol levḥi ki[m] maḥfūẓ idi ${ }^{378}$

546. $238^{\mathrm{a}}$

Fürḳatüñ derdi baña kār eyledi ${ }^{379}$

547. $238^{\mathrm{a}}$

Kāmetüñ ḳopdı kıyāmet eyledi ${ }^{380}$

548. $238^{\mathrm{a}}$

Kāâ ve'l-Ḳur'ān'dur ol māhuñ yüzi ${ }^{381}$

549. $238^{\mathrm{a}}$

550. $238^{\mathrm{a}}$

Kāf-ile nūndan yaratdı 'ālemi ${ }^{382}$

551. $238^{\mathrm{a}}$

Görmüşem her şeyde Haḳk-1 muṭlaḳı ${ }^{383}$

Haḳ'da maḳșūd ne idi hatțuñ yidi ${ }^{384}$

\footnotetext{
${ }^{366}$ Ayan, s. 854; Qəhrəmanov, C. II, s. 474; Araslı, C. II, s. 299; Sədiq, s. 475.

${ }^{367}$ Ayan, s. 856; Qəhrəmanov, C. II, s. 474; Arasl, C. II, s. 299; Sədiq, s. 474.

${ }^{368}$ Ayan, s. 858; Qəhrəmanov, C. II, s. 470; Araslı, C. II, s. 299; Sədiq, s. 473.

${ }^{369}$ Ayan, s. 856; Qəhrəmanov, C. II, s. 478; Arasli, C. II, s. 299; Sədiq, s. 472.

370 Ayan, s. 858; Qəhrəmanov, C. II, s. 470; Araslı, C. II, s. 299.

${ }^{371}$ Ayan, s. 858; Qəhrəmanov, C. II, s. 613; Qəhrəmanov, C. III, s. 197; Araslı, C. II, s. 302; Sədiq, s. 471.

372 Ayan, s. 854; Qəhrəmanov, C. III, s. 195; Arasl, C. II, s. 301; Sədiq, s. 468.

373 Ayan, s. 854; Qəhrəmanov, C. II, s. 476; Araslı, C. II, s. 299; Sədiq, s. 468.

374 Ayan, s. 854; Qəhrəmanov, C. II, s. 476; Araslı, C. II, s. 299; Sədiq, s. 468.

375 Ayan, s. 854; Qəhrəmanov, C. II, s. 475; Araslı, C. II, s. 299; Sədiq, s. 468.

${ }^{376}$ Ayan, s. 855; Qəhrəmanov, C. II, s. 473; Araslı, C. II, s. 300; Sədiq, s. 474.

377 Ayan, s. 857; Qəhrəmanov, C. III, s. 197; Araslı, C. II, s. 301; Sədiq, s. 473. büt-i: perī; ŞR.

378 Ayan, s. 859; Qəhrəmanov, C. III, s. 198; Arasl, C. II, s. 302.

379 Ayan, s. 857; Qəhrəmanov, C. II, s. 472; Arasl, C. II, s. 303; Sədiq, s. 472.

380 Ayan, s. 857; Qəhrəmanov, C. II, s. 473; Araslı, C. II, s. 303; Sədiq, s. 472.

${ }^{381}$ Ayan, s. 856; Qəhrəmanov, C. II, s. 471; Arasli, C. II, s. 303; Sədiq, s. 468.

382 Ayan, s. 855; Qəhrəmanov, C. II, s. 475; Araslı, C. II, s. 303; Sədiq, s. 474.

${ }^{383}$ Ayan, s. 852; Qəhrəmanov, C. II, s. 469; Arasli, C. II, s. 303; Sədiq, s. 474.

${ }^{384}$ Ayan, s. 858; Qəhrəmanov, C. II, s. 471; Arasl, s. 304; Sədiq, s. 473.

Haḳ'da makṣūd ne idi haț̣uñ yidi: Kirpigüñ kaşuñla zülfüñndür yidi; Ayan, Qəhrəmanov, Araslı, Sədiq.
} 
552. $238^{\mathrm{a}} \quad$ Kim ki esrār-1 Nesīmī bilmedi ${ }^{385}$

553. $238^{\mathrm{b}} \quad$ Kim ki Hakak'dan țutmadı pend iy kişi ${ }^{386}$

554. $238^{\mathrm{b}} \quad$ Kim elif tek vāḥid [ü] ferd olmad ${ }^{387}$

555. $238^{\mathrm{b}} \quad$ Dünyeyi benüm diyenler kalmad ${ }^{388}$

556. 238 $\quad$ Maẓhar-1 li'llāh u ekberdür 'Ali

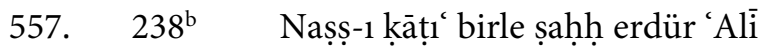

558. $238^{\mathrm{b}} \quad$ Muṣhaf-1 cānda muḳarrardur 'Ali

559. 238 $\quad$ Şìr-i Yezdān şāh-1 merdāndur 'Alī

560. $238^{\text {bh }} \quad$ Gülsitān-1 melekūtdur şāh 'Ali 389

561. 238 $\quad$ Nār-1 Mūsā vü 'așādur şāh 'Alī 390

562. 239 $\quad$ a Çüki 'ilmün şehrine derdür 'Alì

563. 239 $\quad$ Yerde gökde günden izhārdur 'Ali

564. 239 $\quad$ Derd-i dilberden beni dūr eyledi

565. 239 $\quad$ Her kim ol hüsn-i cemāli sevmedi

566. 239 $\quad$ Gözlerüm yaşı muhịtị çağladı

567. 239 $\quad$ Çün yüzün levhinde hat oldı yidi ${ }^{391}$

568. $239^{\mathrm{a}} \quad$ Altı günde yaradıldı üç yidi

569. 239 $\quad$ Șūretüñ Muṣhaf'dur ey ma nā eri

570. 239 $\quad$ Ṭāli uñ mes ūi u burcuñ müşterì

571. 239 $\quad$ Ey perī-simin peri bir bak beri ${ }^{392}$

572. $239^{\mathrm{b}} \quad$ Hạ baña bir hurḳa biçdi kend'özi ${ }^{393}$

573. 239 $\quad$ Şehr-i 'ilmüñ çün 'Ali'dür ḳapusı

574. 239 $\quad$ Fażl-1 Yezdān'uñ yüzüñdür nāmesi

575. 239 $\quad 239^{\mathrm{b}} \quad$ Ey muhịtüñ baḥrinüñ dürdānesi ${ }^{394}$

576. $239^{\text {bh }} \quad$ Vech-i àdem belki Hakk'uñ mazharı

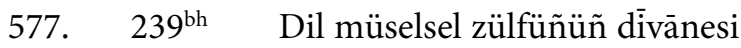

578. 240 $\quad$ İstemekdür yerde gökde çün Haḱ1

579. 240 a Maẓhar-1 zāât-1 Hudā bil ādemi ${ }^{395}$

\footnotetext{
385 Ayan, s. 857; Qəhrəmanov, C. II, s. 477; Araslı, C. II, s. 304; Sədiq, s. 472.

386 Ayan, s. 858; Qəhrəmanov, C. III, s. 199; Arasl, C. II, s. 302.

${ }^{387}$ Ayan, s. 853; Qəhrəmanov, C. II, s. 472; Arasl, C. II, s. 303; Sədiq, s. 472.

388 Ayan, s. 853.

389 Ayan, s. 855.

390 Ayan, s. 855.

${ }^{391}$ Qehremanov, C. III, s. 197; Arasl, C. II, s. 302; Sədiq, s. 473.

392 Qəhrəmanov, C. II, s. 478.

${ }^{393}$ Qəhrəmanov, C. III, s. 194; Arasl, C. II, s. 300; Sədiq, s. 468.

394 Ayan, s. 856.

395 Köksal (2000), s. 196.
} 
580. 240 $20^{a} \quad$ Fażl-1 feyyāż-1 Hudā bil ādemi ${ }^{396}$

581. 240 $\quad$ Eb u cedd-i enbiyā bil Âdem'i ${ }^{397}$

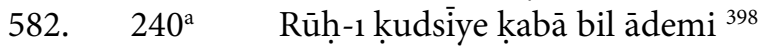

583. 240 a ādemi Fażl-1 Hudā bil ādemi ${ }^{399}$

584. 240 2 a Çeşme-i āb-1 bekā bil ādemi ${ }^{400}$

585. $\quad 240^{\mathrm{a}} \quad$ Haste dildāru'ş-şifā bil ādemi

586. $240^{\mathrm{a}} \quad \bar{A}$ Aemi bildüñ dilerseñ ādemi

587. $240^{\mathrm{a}} \quad$ Çünki țālib bilmez isen ādemi

588. $\quad 240^{\mathrm{b}} \quad$ Nașṣ-1 ḳāṭı hel etā bil ādemi ${ }^{401}$

589. $240^{\mathrm{b}} \quad$ Ṣạhib-i her dü serā bil ādemi ${ }^{402}$

590. $240^{\mathrm{b}} \quad$ Gel beru bil àdem iseñ Ādem'i

591. $240^{\mathrm{b}}$ Oldur ādem kim ura Hak'dan demi

592. $240^{\mathrm{b}}$ Zülf-i 'anber-būya virdüm göñlümi

593. $240^{\mathrm{b}} \quad$ Bir 'acāyib şāha virdüm göñlümi ${ }^{403}$

594. $240^{\mathrm{b}} \quad$ Ey 'Alì şāhum 'Alì māhum 'Alī

595. $241^{\text {a }} \quad$ Rahmet añadur ki bilür kadrini

596. 241 a Zülfüñ ne 'aceb kemend imiş hey

597. 241 $\quad$ Ey șabā behr-i Hudā ol yāre di

\section{Sonuç}

Bu çalışma ile 14. yüzyılda yaşamış olan Seyyid Nesîmî'nin Türkçe Dîvânı'nın bugüne kadar tanıtılmayan ve Nesîmî Dîvânı neşir çalışmalarında dikkate alınması gereken mühim bir kaynak olduğunu düşündüğümüz İstanbul Araştırmaları Enstitüsü Şevket Rado Yazmaları arasında yer alan nüshasının tanıtımı yapılmıştır. Nüsha içinde Rubâiyyât başlığı altında yazılmış 597 şiirin ilk mısraları yazılarak tuyuğ nazım şekliyle yazılmış olan 359 manzumenin bulundukları kaynaklar dipnotlarda gösterilmiştir. Rubâiyyât başlığı altında bulunan ancak önce yapılan neşir çalışmalarında yer almayan 225 tuyuğ ile tuyuğ dışındaki nazım şekilleriyle yazılmış 13 şiirin tam metinlerine yer verilmiştir.

\footnotetext{
${ }^{396}$ Köksal (2000), s. 196.

${ }^{397}$ Köksal (2000), s. 197.

${ }^{398}$ Köksal (2000), s. 197.

${ }^{399}$ Qəhrəmanov, C. II, s. 479; Arasl, C. II, s. 302; Sədiq, s. 468; Köksal (2000), 196.

${ }^{400}$ Köksal (2000), s. 196.

${ }^{401}$ Köksal (2000), s. 197.

402 Köksal (2000), s. 197.

${ }^{403}$ Qəhrəmanov, C. III, s. 195; Arasl, C. II, s. 301; Sədiq, s. 469.
} 
ŞR nüshası ihtiva ettiği 1437 şiirle bugüne kadar tespit edilen Nesîmî Dîvân nüshalarının en hacimlisidir. Yazmada neşredilmemiş 225 tuyuğ yanında daha önceki neşir çalışmalarında olmayan ve çeşitli nazım şekilleriyle yazılmış 200 'den fazla şiir vardır. ŞR nüshasında yer alan neşredilmemiş şiirlerin tamamını tek bir yazıda ele almanın ve makale formatında otaya koymanın çeşitli teknik zorlukları vardır. Bu sebeple çalışmada ŞR nüshasında yer alan şiirlerden sadece tuyuğlar ele alınmış ve yazının konusu özellikle neşredilmemiş tuyuğ metinleriyle sınırlandırılmıştır. Yazmada yer alan diğer manzumelerin ayrıntılı incelemesi başka bir çalışmanın konusudur.

Bu çalışma ile Seyyid Nesîmî'nin ŞR nüshasında bulunan ancak daha önce yayımlanmamış $225^{\prime}$ i tuyuğ, 6'sı Farsça rubai, 5'i nazım ve 2 iki beyitlik gazel nazım şekliyle yazılmış 238 manzumesi ilk kez neşredilmiştir. Böylece Türk edebiyatının en çok tuyuğ yazan şairi olan Nesîmî'nin bilinen tuyuğlarına daha önce neşri yapılmamış 225 tuyuğ daha eklenmiş ve bilim dünyasının dikkatlerine sunulmuştur. Bununla birlikte Nesîmî Dîvânı'nın ŞR nüshasında bulunan ve bu çalışma ile neşri yapılan 225 tuyuğ ve diğer 13 manzumenin bazılarının Nesîmî'ye aidiyeti konusunda ihtiyatlı olmak gerektiği düşüncesindeyiz. Bu ihtiyat payını unutmamak kaydıyla bahse konu tuyuğ ve diğer manzumelerin aksini kanıtlayacak yeni verilere ulaşılıncaya kadar Nesîmî'ye ait olan veya ona atfedilen şiirler kabul edilerek yayımlanmasının klasik Türk edebiyatı alanına katkı sağlayacağı inancındayız. 


\section{Kaynakça}

Araslı, Hamid (hzl.) (2004). İmâdüddin Nesîmî, Seçilmiş Eserleri 2 Cilt, Bakı: Lider Neşriyat.

Aslan, Üzeyir (2016). Ivaz Paşa Oğlu Atayi (ö.1437) Divanı. İstanbul: Kriter Yayınları. Ayan, Hüseyin (1970). Nesîmî, Hayatı, Edebî Kişiliği, Eserleri ve Türkçe Divanının Metni. Doktora Tezi. Erzurum: Atatürk Üniversitesi.

Ayan, Hüseyin (1974). Kul Nesîmî'ye Ait Olduğu Sanılan Şiirler. Atatürk Üniversitesi Edebiyat Fakültesi Araştırma Dergisi, Sayı. 6, Erzurum.

Ayan, Hüseyin (2014). Nesîmî Hayatı, Edebî Kişiliği, Eserleri ve Divanının Tenkitli Metni [Birleştirilmiş Baskı], Ankara: TDK Yay.

Başgöz, İlhan (1986) Karac'oğlan Geleneği. Folklor Yazıları. İstanbul: Adam Yayınları.

Cengiz, Halil Erdoğan (1986). Türk Şiirinde Musammatlar. Türk Dili Dergisi, Türk Șiiri Özel Sayısı II. Ankara: TDK Yayınları.

Çalka. Mehmet Sait (2019). Klasik Türk Şiirinde Tuyuğ. İstanbul: Kriter Yayınevi.

İlaydın, Hikmet (1964). Türk Edebiyatında Nazım. İstanbul: İnkılab ve Aka Kitabevi.

İpekten, Haluk (1994). Eski Türk Edebiyatı Nazım Şekilleri ve Aruz. İstanbul: Dergâh Yayınları.

İstanbul Araştırmaları Enstitüsü Yazma Eserler Kataloğu, 3 Cilt. (2014) (Hazırlayanlar: Günay Kut, Zehra Toska, Fatma Büyükkarcı Yılmaz, Tülay Gençtürk Demircioğlu, Arzu Atik) İstanbul: İstanbul Araştırmaları Enstitüsü.

Köksal, M. Fatih (2000). Seyyid Nesîmî'nin Bilinmeyen Tuyuğları. Journal of Turkish Studies, Agâh Sırrı Levend Hatıra Sayısı II, V. 24, Harvard University Press 2000, 182-208.

Köksal, M. Fatih (2009). Seyyid Nesîmî'nin Yayımlanmamış Şiirleri. Türk Kültürü ve Hacı Bektaş Velî Araştırma Dergisi -Hacı Bektaş Velî'nin 800. Doğum Yıl Dönümü Anisina- (50): 77-135.

Köprülü, M. Fuad (1989). Edebiyat Araştırmaları 2. İstanbul: Ötüken Neşriyat.

Kurnaz Cemal-Çeltik Halil (2013). Divan Şiiri Şekil Bilgisi. Ankara: Berikan Yayınları.

Macit, Muhsin (2016). Hatâyînin Yayımlanmamış Gazelleri. Türklük Bilimi Araştırmaları (TÜBAR), Sayı: 39, s. 115-153. 
Oğuz, Öcal (2003). Birincil Sözlü Kültür Çağı ve Karac’oğlan Şiiri. Millî Folklor. Y1l: 15, Say1: 58, s. 31-38.

Onay, Ahmet Talat (1996). Türk Şiirlerinin Vezni. (haz. Cemal Kurnaz), Ankara: Akçağ Yayınları.

Özdemir, Mehmet (2020). Seyyid Nesîmî Dîvânı'nın Kayda Değer Bir Nüshası ve Şairin Neşredilmemiş Türkçe Şiirleri. Divan Edebiyatı Araştırmaları Dergisi, Sayı 24, Bahar/Spring 2020.

Öztelli, Cahit (1969). On Yedinci Yüzyıl Tekke Şairi Kul Nesîmî. Ankara: Türk Etnoğrafya, Folklor ve Turizm Derneği Yayını: 3.

Öztoprak, Nihat (2012). Tuyuğ. DİA, C. 41, İstanbul: Türkiye Diyanet Vakfı Yayınları. Paşayev, Qəzənfər (2018). İmadəddin Nəsimi, İraq Divanı. Bakı: CBS-PP.

Paşayevtoru, Qəzənfər (1987). Mövlanə Seyid İmadaddin Nasimi əbülfəzl, İraq Divanı. Bakı.

Qəhrəmanov, Cihangir (1973). İmâdüddîn Nesîmî, Eserleri. 3 C, Bakı: Azerbaycan SSR İlimler Akademiyası Respublika El Yazmalar Fondu "İlim" Neşriyatı. Redaktör: Hamid Arasli.

Saraç, M. A. Yekta (2007). Klasik Edebiyat Bilgisi Biçim-Ölçü-Kafiye. 2. Baskı. İstanbul: 3F Yayınları.

Sədiq (Düzgün), Hüseyn Məhəmmədzadə (2008). Seyyid İmadəddin Nəsimi, Türkçe Divanı. Təbriz şəhəri: Jxtər Nəşriyyatı.

Seyyid Nesîmî, Divān-ı Nesîmî. İstanbul Araştırmaları Enstitüsü, Şevket Rado Yazmaları Nu. 000002.

Zülfe, Ömer (2005). "Seyyid Nesîmî'nin Tuyuğlarına Ek", Modern Türklük Araştırmaları Dergisi, 2(4) 121-135. 


\begin{tabular}{|c|c|c|}
\hline \multicolumn{3}{|c|}{$\begin{array}{c}\text { METİN } \\
\text { (Nesîmî Dîvânı ŞR Nüshasında Yer Alan Neşredilmemiş Tuyuğlar) }\end{array}$} \\
\hline \multicolumn{3}{|r|}{ Harfü'l-Elif } \\
\hline 001. & $203^{b}$ & 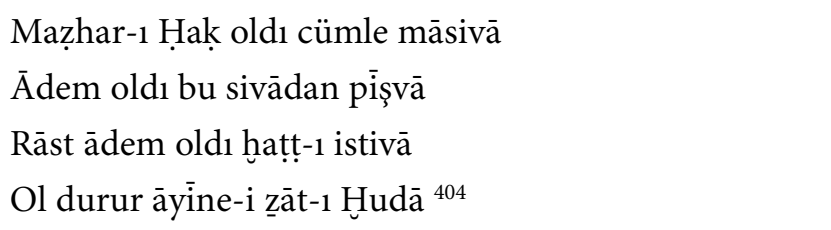 \\
\hline 002. & $203^{b}$ & $\begin{array}{l}\text { Ehl-i taṭīir olduñ-ise țālibā } \\
\text { Gör bu kehf içinde hatṭt-1 istivā } \\
\text { Kelb nefsüñ uydurur olsañ saña } \\
\text { Huāk-i cismüñ olmaya bād-ı hevā }\end{array}$ \\
\hline 003. & $203^{\mathrm{b}}$ & $\begin{array}{l}\text { Cehd ḳıl ol ey ‘azīiüm mehci‘ā } \\
\text { Mehci'ā olmaḳ gerekdür mehci‘ā } \\
\text { Kim ki oldı mehci'ā vü behci'ā } \\
\text { Öyle bil Hạa andan oldı nehci'āa }\end{array}$ \\
\hline 004. & $203^{b}$ & $\begin{array}{l}\text { Kim ki beñzetdi hilāli ḳaşuña } \\
\text { Üşdi sevdā-yı gam anuñ başuna } \\
\text { Kim ki olmadı anuñla āşinā } \\
\text { Yolda ḳaldı yetmedi yoldaşuna }\end{array}$ \\
\hline 005. & $203^{\text {bh }}$ & $\begin{array}{l}\text { Șūretüñ kimdür kemāhī Muṣṭafā } \\
\text { Muṣtafā'nuñ șūretidür Murteżā } \\
\text { Nūr-1 vāḥidsüz aḥaddur aduñuz } \\
\text { Ey ḳadüñ ṭūbā cemālüñ müntehā }\end{array}$ \\
\hline 006. & $203^{\text {bh }}$ & $\begin{array}{l}\text { Ey güzel cāna yeter eyle cefā } \\
\text { Müdde`īi-le göz göre zevḳ u ṣafā } \\
\text { Yoluña ben cān u baş terk eylerem } \\
\text { Raḥmüñi aġyāra iderseñ şehā }\end{array}$ \\
\hline
\end{tabular}

\footnotetext{
${ }^{404} 1 / 2$ pişvā: bī-nevā; ŞR. Metinde müstensih ya da musahhih tarafindan yapılanm düzeltmeler burada olduğu gibi gösterildi.
} 


\begin{tabular}{|c|c|c|}
\hline \multicolumn{3}{|r|}{ Harfü'l-Bā } \\
\hline 007. & $203^{\mathrm{b}}$ & $\begin{array}{l}\text { Yanag̉uñ nūrına hayrān āfitāb } \\
\text { Alnuña eyler sücūdı māhtāb } \\
\text { Çünki ref oldı cemālüñden niḳāb } \\
\text { Hakkk'ı gör oldı 'ayān min külli bāb }{ }^{405}\end{array}$ \\
\hline 008. & $204^{\mathrm{a}}$ & $\begin{array}{l}\text { Ey ḥabībī cānib-i Haḳ'dan hițāb } \\
\text { Saña fāsık ad olındı çün cevāb } \\
\text { Pes olındı her zamān mest ü ḩarāb } \\
\text { Söz budur va'llāhu a'lem bi'ṣ-ṣavāb }\end{array}$ \\
\hline 009. & $204^{\mathrm{a}}$ & $\begin{array}{l}\text { Çünki yüzüñden götürüldi hịcāb } \\
\text { Ru’yet içün olısardur feth-i bāb } \\
\text { Anda bunda gör dimekden yoḳ zamān } \\
\text { Bil yaḳin va'llāhu a'lem bi'ṣ-ṣavāb }\end{array}$ \\
\hline 010. & $204^{\mathrm{a}}$ & $\begin{array}{l}\text { Zāhidā esmā içün ḳılsañ 'itāb } \\
\text { N'eylesün ol çünki a'mādur hițāb } \\
\text { Mendedür çün āyet-i şābbü kaṭat } \\
\text { Diñle şundan andadur ümmü'l-kitāb }\end{array}$ \\
\hline 011. & $204^{\mathrm{a}}$ & $\begin{array}{l}\text { Efendüm vefālu gerekdür hạaīib } \\
\text { Vefālu olıcaḳ yaraşur țabīb } \\
\text { Gerekdür yaraşur ben olam nașīb } \\
\text { Habīb ü tabīi ü nașib ü garīib }{ }^{406}\end{array}$ \\
\hline 012. & $204^{\text {bh }}$ & $\begin{array}{l}\text { Gözlerüñ 'āşıkları ḳılur memāt } \\
\text { Leblerüñ mürdelere virür hayāt } \\
\text { Ben çekerem dem-be-dem ḳahruñ senüñ } \\
\text { Sen idersüñ müdde‘ìye iltifāt }\end{array}$ \\
\hline
\end{tabular}

\footnotetext{
${ }^{405}$ 7/3 nikāā: hịcāb; ŞR.

${ }^{406}$ feûlün feûlün feûlün feûl. 11/1 efendüm: bize ol; 11/3 ben olam: bize ol; ŞR.
} 


\begin{tabular}{|c|c|c|}
\hline \multicolumn{3}{|r|}{ Harfüt-Tā } \\
\hline 013. & $205^{\mathrm{a}}$ & $\begin{array}{l}\text { Ey meyi ‘İsā-lebüñ 'aynu'l-hayāt } \\
\text { Āb-ı hayvāndur lebüñ kand-i nebāt } \\
\text { Ṣūretüñ yazusı oldı müfredāt } \\
\text { Fā'ilātün fā'ilātün fā'ilāt }{ }^{407}\end{array}$ \\
\hline 014. & $205^{\mathrm{a}}$ & 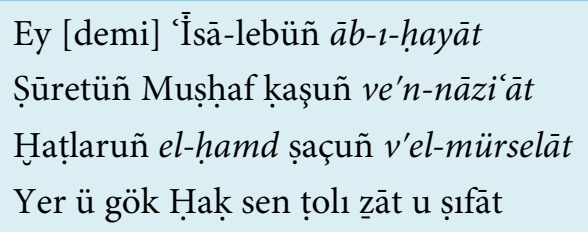 \\
\hline 015. & $205^{\mathrm{a}}$ & $\begin{array}{l}\text { Ma'rifetdür ṭālibā āb-ı hạāàt } \\
\text { Ma'rifetdür ẓulmete cümle necāt } \\
\text { Ma'rifetsüz kişi olur bī-șebāt } \\
\text { Ma'rifet kesb eyleyen bulur șebāt }\end{array}$ \\
\hline 016. & $205^{\mathrm{a}}$ & $\begin{array}{l}\text { Bu ḥurūfdur otuz iki müfredāt } \\
\text { Oldı țalib hem ṣıfat hem 'ayn-ı zaāt } \\
\text { Buña maẓhardur ser-ā-ser kā’ināt } \\
\text { Gör münezzehdür bunı ez-şeş cihāt }\end{array}$ \\
\hline 017. & $205^{\mathrm{a}}$ & $\begin{array}{l}\text { Zulmet içre hāṣıl itdüm ben hayāt } \\
\text { İrmeyiserdür baña hergiz memāt } \\
\text { Bu şarābı içmek içün niçeler } \\
\text { İstediler bulmadılar ẓulumāt }\end{array}$ \\
\hline 018. & $205^{\mathrm{b}}$ & $\begin{array}{l}\text { Ey dişüñ lü’lü’ lebüñ āb-ı hayāt } \\
\text { Șoran anı bulmayısardur memāt } \\
\text { Sözine ḳılur şehā[de]t şeş cihāt } \\
\text { Kim senüñ tek gelmedi 'ālemde žāt } 408\end{array}$ \\
\hline
\end{tabular}

\footnotetext{
${ }^{407}$ ŞR nüshasında terkipler “meyi ‘īsā, demi ‘Iَsā” örneklerinde olduğu gibi yer yer belirtme hal eki ile

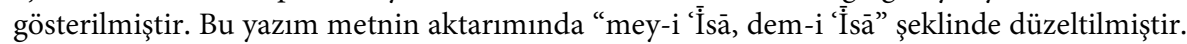
${ }^{408}$ Metin tamirine ihtiyaç duyulan yerlerde yapılan eklemeler köșeli parentez [ ] içinde yazılmıştır.
} 


\begin{tabular}{|c|c|c|}
\hline 019. & $205^{\mathrm{b}}$ & $\begin{array}{l}\text { Ķứa-i devletde oynat ey dil at } \\
\text { Şāh ruh gözlerse at at ata at } \\
\text { Beydaḳ u fill oyna ferz-i rūḥ-ile } \\
\text { Key șaḳın kim olmayasın şāh māt }\end{array}$ \\
\hline 020. & $205^{\mathrm{b}}$ & $\begin{array}{l}\text { Kim ezel 'ahdinde șādıḳdur dürüst } \\
\text { Devlet-i erkānı olmaz hīç süst } \\
\text { İ'tiḳādı behr-i dīndür herkesüñ } \\
\text { Ṭog̀rulık yolında ger oldıysa cüst }{ }^{409}\end{array}$ \\
\hline 021. & $205^{\mathrm{b}}$ & $\begin{array}{l}\text { Yüzüñ devrinde hatm oldı 'alāmet } \\
\text { Ṣaçuñ esrārıdur rāh-1 selāmet } \\
\text { Gözüñ ider aña vaḥy-i imāmet } \\
\text { Ruhuñ gören kişi oldı melāmet }{ }^{410}\end{array}$ \\
\hline 022. & $205^{\mathrm{b}}$ & $\begin{array}{l}\text { Habībi dil sarāyın ḳıldı halvet } \\
\text { İder her dem-be-dem yār-ile șoḥbet } \\
\text { O vaṣl-ı yār-ile çün buldı vuṣlat } \\
\text { Ne gam kim halḳ ide aña meẓemmet }{ }^{411}\end{array}$ \\
\hline \multicolumn{3}{|r|}{ Ḥarfü'd-Dāl } \\
\hline 023. & $206^{\mathrm{b}}$ & 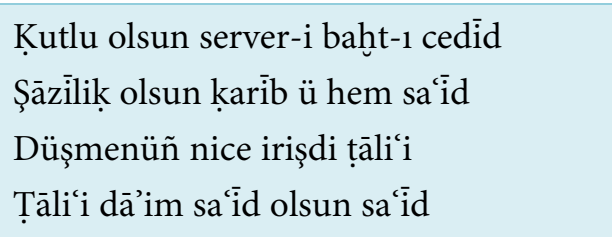 \\
\hline \multicolumn{3}{|r|}{ Ḥarfü'r-Rā } \\
\hline 024. & $207^{\mathrm{bh}}$ & $\begin{array}{l}\text { Haḳ Te ālā'nuñ ṣıfātı sendedür } \\
\text { Hạk-ṣ̂fāt ol belki zāātı sendedür } \\
\text { Cümle ‘alem müfredātı sendedür } \\
\text { Biñ bir aduñ ism ü zaātı sendedür }\end{array}$ \\
\hline
\end{tabular}

\footnotetext{
${ }^{409}$ 21/1 kim ezel: kim ki öz; 21/3 herkesüñ: her kişi; ŞR.

${ }^{410}$ mefầlün mefâillün fê̂lün. 22/2 rāh-1: dār-1; 22/4 gören kişi oldı melāmet: āşı̣ları ḳıldı melāmet; ŞR.

${ }^{411}$ mefâillün mefâillün feûllün.
} 


\begin{tabular}{|c|c|c|}
\hline 025. & $208^{\mathrm{b}}$ & $\begin{array}{l}\text { Ey cemālüñ otuz iki hatț-1 nūr } \\
\text { V'ey țudagiuñ şerbeti } m \bar{a}^{\prime}-i \text { țahūr } \\
\text { Ey yüzinde iki fażl oldı zuhūr } \\
\text { Şol șırāțu'llāh men ḳıldum 'ubūr }{ }^{412}\end{array}$ \\
\hline 026. & $210^{\mathrm{a}}$ & $\begin{array}{l}\text { Sī vü dü çünki kelām-ı Kirdigār } \\
\text { Yerde gökde işidüp söyler a yār } \\
\text { Çün o nuțḳuñ mazhharıdur ne ki var } \\
\text { Sen seni bil kim nesen ey pīi ü kār }{ }^{413}\end{array}$ \\
\hline 027. & $210^{\mathrm{a}}$ & $\begin{array}{l}\text { 'Arş u ferş [u] mā-siva'llāh ne ki var } \\
\text { Çünki bir nūra mezāhirrdür i yār } \\
\text { Sen i țālib vaḥdete it i'tibār } \\
\text { Bu taḳarrübden geçegör zinhār }\end{array}$ \\
\hline 028. & $210^{\mathrm{a}}$ & $\begin{array}{l}\text { Senden özge kim didi ālemde var } \\
\text { Maẓharuñdur ādemi ādemde var } \\
\text { Ādem ü ālem ḳamu senden țolı } \\
\text { Kim bilür bu sırrı kim maḥremde var }\end{array}$ \\
\hline 029. & $210^{\mathrm{a}}$ & $\begin{array}{l}\text { Șūret ü ma'nā durur her ne ki var } \\
\text { Ṣūret ü ma'nā çü sensen ey nigār } \\
\text { Ma'nī gözgü șūret oldı āşikār } \\
\text { Ma'nī șūret atına oldı süvār }{ }^{415}\end{array}$ \\
\hline 030. & $210^{\mathrm{a}}$ & $\begin{array}{l}\text { Bizüz ol abdāl-ı Rūm hayrān u zār } \\
\text { K'itdi 'aşḳuñ odı bizi 'ayn-ı nār } \\
\text { Çünki rind-i lā-mekānuz bi-karāār } \\
\text { Bu sebebden şehrimüzdür her diyār }\end{array}$ \\
\hline
\end{tabular}

\footnotetext{
${ }^{412}$ Nesîmî "fażl” kelimesini çoğu yerde tevriyeli kullanmıştır.

${ }^{413}$ 27/1 si vü dü: çün sì dü, ŞR.

414 3. misrada vezin aksiyor.

${ }^{415}$ 30/2 ey nigār: bil nigār; ŞR.
} 


\begin{tabular}{|c|c|c|}
\hline 031. & $210^{\mathrm{a}}$ & $\begin{array}{l}\text { Biz deli abdāl-ı Rūm'uz ey nigār } \\
\text { Olmuşuzdur șaçlaruñ-veş tārumār } \\
\text { Bülbül-i cān göreli gün yüzini } \\
\text { Kār u kesbüm her gün oldı āh u zār }\end{array}$ \\
\hline 032. & $210^{\mathrm{a}}$ & $\begin{array}{l}\text { Haḳ kelāmı kendi nūrumdur i yār } \\
\text { Sen de gör ol nūrı olma ehl-i nār } \\
\text { Yedi huaṭla sācid ol sen zīnhār } \\
\text { Olma şeytān tek la ín-i bì-ḳarār }{ }^{416}\end{array}$ \\
\hline 033. & $210^{\mathrm{b}}$ & $\begin{array}{l}\text { Dürr-i deryā-yı țarikāāt bendedür } \\
\text { Pertev-i burc-1 hakạiḳat bendedür } \\
\text { Şol ki haț̣̂ devrini bildi tamām } \\
\text { Bildi kim sırr-1 şerīat bendedür }\end{array}$ \\
\hline 034. & $210^{\mathrm{b}}$ & $\begin{array}{l}\text { Küntü kenzüñ ma'nīsi ādemdedür } \\
\text { Ādem oldur bir naẓar bir demdedür } \\
\text { Sīne-i Mecnūn ezelden gamdadur } \\
\text { Yevm-i Leylā dā'im ol hürremdedür }\end{array}$ \\
\hline 035. & $210^{\mathrm{b}}$ & $\begin{array}{l}\text { Ey gönül Haḳ muṭlaḳ ol dilberdedür } \\
\text { Her ne kim isterseñ ol serverdedür } \\
\text { Muṣhaf'uñ haț̣ı çün ol defterdedür } \\
\text { Defter ol kim nūrdan perverdedür }\end{array}$ \\
\hline 036. & $210^{\mathrm{b}}$ & $\begin{array}{l}\text { Sünbülüñ kim ṣad hezārān destedür } \\
\text { Her ḳılında biñ dil ü cān bestedür } \\
\text { Tīr-i ġamzeñden bu cānum ḩastedür } \\
\text { Gün yüzinden țāliı̈m huucestedür }\end{array}$ \\
\hline 037. & $210^{\mathrm{b}}$ & $\begin{array}{l}\text { Gamzeñ oḳı cānuma peyvestedür } \\
\text { Sünbülüñden hāṭ̂rum ser-geștedür } \\
\text { Sükkerīn la'lüñ ki şirīn-bestedür } \\
\text { Cāna șor kim gözlerüñden küştedür }{ }^{417}\end{array}$ \\
\hline
\end{tabular}

\footnotetext{
416 33/3 hațla: hatța, ŞR.

417 37/3 laclüñ ki: la‘lüñle; ŞR.
} 


\begin{tabular}{|c|c|c|}
\hline 038. & $210^{\text {bh }}$ & $\begin{array}{l}\text { Ol nedür kim ayaġı başındadur } \\
\text { Șūret ü ma'nā anuñ aşındadur } \\
\text { Ag̀zzı birdür dili iki cānı yoḳ } \\
\text { 'Ömri hem otuz iki yaşındadur }\end{array}$ \\
\hline 039. & $211^{\mathrm{a}}$ & $\begin{array}{l}\text { Haberler içre bu bir hoş haberdür } \\
\text { Mü’esssirden görinen bir eșerdür } \\
\text { Ne bilsün naḳşı nice yazdı naḳ̄āş } \\
\text { Olar kim bu eșerden bī-haberdür }{ }^{418}\end{array}$ \\
\hline 040. & $211^{\mathrm{a}}$ & $\begin{array}{l}\text { Çün cemālüñ kün fekānuñ zāāıdur } \\
\text { Șūretüñ levḥi anuñ iṣbātıdur } \\
\text { Pes ene'l-ḥaḳ söylerem Manșūr tek } \\
\text { Bilmeyen bu sırrı şeyțān atıdur }\end{array}$ \\
\hline 041. & $211^{\mathrm{a}}$ & $\begin{array}{l}\text { Sī vü dü çünkim cihānda bāḳidür } \\
\text { Leblerüñ cāmından içen sāḳidür } \\
\text { Ehrimen'e șunma anı şākīiür } \\
\text { Șusuz ölmek seglerin çün hāḳīiür }{ }^{419}\end{array}$ \\
\hline 042. & $211^{\mathrm{a}}$ & 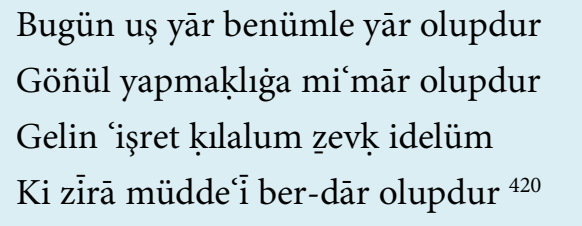 \\
\hline 043. & $211^{\mathrm{a}}$ & $\begin{array}{l}\text { Șubh u şām ‘āşıḳlaruñ seyrānıdur } \\
\text { Her nefes ‘āriflerüñ bayramıdur } \\
\text { Her zamān bir 'āşıkuñ devrānıdur } \\
\text { Her 'āşık bir ma'şūkenñ hayrānıdur }{ }^{421}\end{array}$ \\
\hline
\end{tabular}

\footnotetext{
${ }^{418}$ mefầllün mefâîlün feûlün.

${ }^{419}$ 41/1 si vü dü: hatț-1 çün; 41/4 seglerin çün: ölenlerüñ; ŞR.

${ }^{420}$ mefầlü̈n mefầlü̈n feûlün. Musahhih "uş yār" kelimelerinde takdim tehir yapmıştır.

${ }^{421}$ 43/4 āşsı ve ma şūụ kelimelerinde zihaf yapılmış.
} 


\begin{tabular}{|c|c|c|}
\hline 044 & $211^{\mathrm{a}}$ & $\begin{array}{l}\text { Her kişi kim șāḥib-i idrāḳ olur } \\
\text { Márifetden cüst ü hem çālāk olur } \\
\text { Hem şerīketden vücūdı pāk olur } \\
\text { Menzili dā’im anuñ eflāk olur }\end{array}$ \\
\hline 045. & $211^{\mathrm{b}}$ & $\begin{array}{l}\text { Gice gündüz 'aşk eri bīdār olur } \\
\text { Mest ü hayrān vālih ü didār olur } \\
\text { Küfr ü dīn rūy [u] zülf-i yār olur } \\
\text { 'Aşk odına ḩār u has gülzār olur }\end{array}$ \\
\hline 046. & $211^{\mathrm{b}}$ & 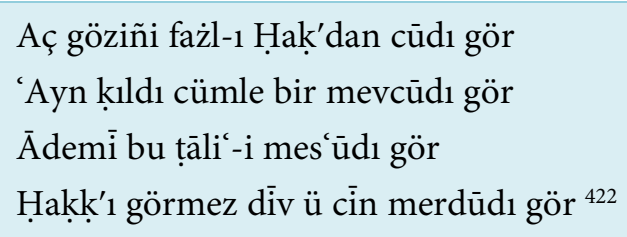 \\
\hline 047. & $211^{\mathrm{b}}$ & $\begin{array}{l}\text { Aç gözüñ her yerde kāf u nūnı gör } \\
\text { ‘Ayn-1 zāāt-1 Hālikẹ-1 bī-çūnı gör } \\
\text { Her kitābda yazılu meknūnı gör } \\
\text { Anı görmez dīv u cin mel'ūnı gör }\end{array}$ \\
\hline 048. & $211^{\mathrm{b}}$ & $\begin{array}{l}\text { ‘Āḳil iseñ aç gözüñi ānı gör } \\
\text { Āyine yüzine baḳ Mecnūn'ı gör } \\
\text { 'Ayn-ı vaḥdet oldı ulu bunı gör } \\
\text { Keșretüñ içinde kạalan dūnı gör }\end{array}$ \\
\hline 049. & $211^{\mathrm{b}}$ & $\begin{array}{l}\text { Sāye-i zulluñ hümāsı gün durur } \\
\text { Ol gidicek zulmet-ile dün durur } \\
\text { Āh u efgān itdigümden ün durur } \\
\text { Kudretinden çarh-1 gerdūn döndürür }\end{array}$ \\
\hline 050. & $212^{\mathrm{a}}$ & $\begin{array}{l}\text { Ey ḳarındaş bil ölüm uyhu durur } \\
\text { Uyumak 'aşḳ ehline bed-hūu durur } \\
\text { Vech-i dilber cennet-i mīnū durur } \\
\text { Biz delüye anı sevmek hū durur }\end{array}$ \\
\hline
\end{tabular}

${ }^{422} 46 / 2$ bir: bu; ŞR. 


\begin{tabular}{|c|c|c|}
\hline 051. & $212^{\mathrm{a}}$ & $\begin{array}{l}\text { Biz ki bir abdāl-ı Rūmuz ki fakīir } \\
\text { Derdmend ü haste vü hor u haḳīi } \\
\text { Düşmüşüz elden ayaḳdan ey emīr } \\
\text { Fażl'uñ ile sen bize ol destgìr }{ }^{423}\end{array}$ \\
\hline 052. & $212^{\mathrm{a}}$ & 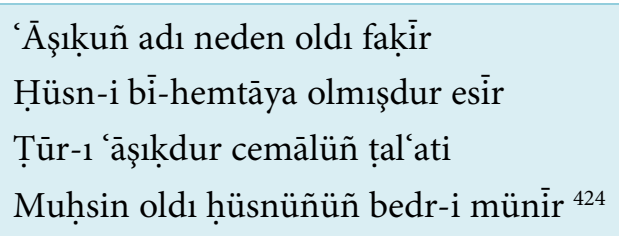 \\
\hline 053. & $212^{\mathrm{a}}$ & $\begin{array}{l}\text { Sende senlikden niçe kim var eșer } \\
\text { Dost yüzin görmez gözüñ söz muhtașar } \\
\text { Senligüñden sen geçerseñ ey beşer } \\
\text { Dost yüzini göresin çün mā-ḥażar }\end{array}$ \\
\hline \multicolumn{3}{|r|}{ Ḥarfü'z-Zā } \\
\hline 054. & $212^{\mathrm{b}}$ & $\begin{array}{l}\text { Şāh-1 merdān 'Alī'dür sulțānumuz } \\
\text { Şāh Ḥüseyn'e ḳurbān olsun cānumuz } \\
\text { Başımı top eyledüm meydānına } \\
\text { Kerbelā yazusıdur meydānumuz }\end{array}$ \\
\hline 055. & $212^{\mathrm{b}}$ & $\begin{array}{l}\text { Ey yüzi gül dili bülbül şāhumuz } \\
\text { Hamdüli'llāh kim işitdüñ āhumuz } \\
\text { Yine tọġı istivāmuz māhumuz } \\
\text { Fażl-1 iḥsān eyledi Allāh'umuz }\end{array}$ \\
\hline 056. & $213^{\mathrm{a}}$ & $\begin{array}{l}\text { 'Ayn u şin u kāāa düşdi göñlümüz } \\
\text { Ṣanki kūh-1 Kāf'a düşdi göñlümüz } \\
\text { Yār-1 pür-elțāfa düşdi göñlümüz } \\
\text { Șanmañuz kim lāfa düşdi göñlümüz }\end{array}$ \\
\hline
\end{tabular}

\footnotetext{
${ }^{423}$ 51/4 Fażl'uñ ile: Fażl'uñ-ile; ŞR.

${ }^{424}$ 52/4 hüüsnüñüñ: hüsnüñle; ŞR.
} 


\begin{tabular}{|c|c|c|}
\hline 057. & $213^{\mathrm{a}}$ & $\begin{array}{l}\text { Gözleri şehlāya düşdi göñlümüz } \\
\text { Ḳāmet[i] bālāya düşdi göñlümüz } \\
\text { Hüsn[i] bì-hemtāya düşdi göñulümüz } \\
\text { Bir yüzi bedr aya düşdi göñlümüz }\end{array}$ \\
\hline 058. & $213^{b}$ & $\begin{array}{l}\text { Şāh-1 sīm-endāma düşdi göñlümüz } \\
\text { Zülf-i 'anber-dāma düşdi göñlümüz } \\
\text { Çünki bizi șāìm ol dem itdi 'aş̣ } \\
\text { Lā-cerem bayrama düşdi göñlümüz }\end{array}$ \\
\hline 059. & $213^{\mathrm{b}}$ & $\begin{array}{l}\text { Biz ki şems ile ḍuhāda gelmişüz } \\
\text { Rāst-1 ḩațte-1 istivāda gelmişüz } \\
\text { Pāk-dīn-i ítikāāa gelmişüz } \\
\text { Nefs-i kāfirle cihāda gelmişüz }\end{array}$ \\
\hline 060. & $213^{\mathrm{b}}$ & $\begin{array}{l}\text { Emr-i Ḥak'dur çün cihāda gelmişüz } \\
\text { Ser-be-ser bu māsivāāa gelmişüz } \\
\text { Va'de-i yevmi'l-bekāāda gelmişüz } \\
\text { Bu fenā dāra bețāda gelmişüz }\end{array}$ \\
\hline 061. & $213^{b}$ & $\begin{array}{l}\text { Biz ki varuz șanma yoḳdan gelmişüz } \\
\text { Key șaḳın yaḳın ıraḳdan gelmişüz } \\
\text { Biz vücūda zַāt-1 Haḳ'dan gelmişüz } \\
\text { Az degül bu mülke çoḳdan gelmişüz }\end{array}$ \\
\hline 062. & $214^{\mathrm{a}}$ & $\begin{array}{l}\text { Ebced og̉lı yüz sebaḳdan gelmişüz } \\
\text { Ţālibü'l-'ilmüz u zevḳden gelmişüz } \\
\text { Nūr-1 dīdāruz şafaḳdan gelmişüz } \\
\text { Hālıḳ-1 Rabbü'l-felaḳdan gelmişüz }\end{array}$ \\
\hline 063. & $214^{\mathrm{a}}$ & $\begin{array}{l}\text { Biz ki derd-i 'aşḳa demsāz olmışuz } \\
\text { Rind-i kallāşuz naz̧ar-bāz olmışuz } \\
\text { Çünki Fażl-1 Ḥaḳk'a feyyāż olmışuz } \\
\text { 'Āleme şāh-ı ser-efrāz olmışuz }\end{array}$ \\
\hline
\end{tabular}




\begin{tabular}{|c|c|c|}
\hline 064. & $214^{\mathrm{a}}$ & $\begin{array}{l}\text { Biz ki Rūm içinde abdāl olmışuz } \\
\text { Bu cihāndan fāriġu'l-bāl olmışuz } \\
\text { Çün fenā mülkinde pā-māl olmışuz } \\
\text { Hoş mübārek vaḳt-i ḩoş-hāa olmışuz }\end{array}$ \\
\hline 065. & $214^{\mathrm{a}}$ & $\begin{array}{l}\text { Biz ki dīdāruña 'āşık olmışuz } \\
\text { 'Aşșıñuñ yolında șādık olmışuz } \\
\text { Halḳ içinde çün münāfık olmışuz } \\
\text { Raḥmet-i fażlıña lāyık olmışuz }{ }^{425}\end{array}$ \\
\hline 066. & $214^{\mathrm{a}}$ & $\begin{array}{l}\text { Biz ki dirlik 'āleminde ölmişüz } \\
\text { Mūtū ḳable en temūtū olmışuz } \\
\text { Vahetüñ deryāsına çün țalmışuz } \\
\text { Ol dür-i yektāyı bil kim almışuz }\end{array}$ \\
\hline 067. & $214^{\mathrm{a}}$ & $\begin{array}{l}\text { Biz ki cām-1 'aşk-ile mest olmışuz } \\
\text { Varlığımuz giderüp hest olmışuz } \\
\text { Dört yidi dört kez dahı heşt olmışuz } \\
\text { Belki bu ma'nā ile şașt olmışuz }\end{array}$ \\
\hline 068. & $214^{\mathrm{b}}$ & $\begin{array}{l}\text { Çün bu fānī 'ālem içre fānìyüz } \\
\text { Ol sebebden kā'inātuñ cānıyuz } \\
\text { Şūretā gerçi ki biz cismānīyüz } \\
\text { Sīret-i ma'nīde hod rūhānīyüz }\end{array}$ \\
\hline 069. & $214^{\mathrm{b}}$ & $\begin{array}{l}\text { Gerçi biz bu 'ālemüñ ḳallāşıyuz } \\
\text { Rind ü evbāş ḳaylı vü ḳallāşıyuz } \\
\text { Lìkin ol pīr-i mugāān işiginüñ } \\
\text { Bir kemīne kemterīn ferrāşıyuz }\end{array}$ \\
\hline 070. & $214^{\mathrm{b}}$ & $\begin{array}{l}\text { Biz ol abdāl-ı Rūm-ı bī-nevāyuz } \\
\text { Ki her dem derd-i yāra mübtelāyuz } \\
\text { Fenā dārında gerçi kim fenāyuz } \\
\text { Beḳā dārında baḳ ḥayy ü beḳāyuz }{ }^{426}\end{array}$ \\
\hline
\end{tabular}

\footnotetext{
${ }^{425}$ 65/2 "yolında" örneğinde olduğu gibi yazmada yer yer "zamir n'si” nûn (ن) ile yazılması gerekirken kef (ك) ile yazılmıştır. Bu şekildeki yanlış yazımlar transkripsiyonda düzeltilmiştir.

${ }^{426}$ mefâillün mefâillün feûllün.
} 


\begin{tabular}{|c|c|c|}
\hline 071. & $214^{\mathrm{b}}$ & $\begin{array}{l}\text { Biz ki ol Fażlullāh'uñ leşkeriyüz } \\
\text { Kün elinden zuhūr itmiş çeriyüz } \\
\text { Çünki abdālān-1 Rūm'uñ eriyüz } \\
\text { Selāținn-i cihānuñ serveriyüz }{ }^{427}\end{array}$ \\
\hline 072. & $214^{\mathrm{b}}$ & 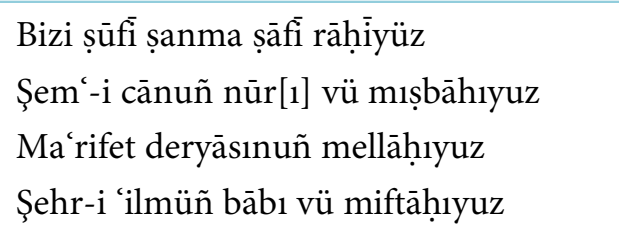 \\
\hline 073. & $214^{\mathrm{b}}$ & $\begin{array}{l}\text { Fażl-ı Hak'dan biz ki ‘ālī-meşrebüz } \\
\text { Rind-i ḳallāşuz müberreh mežhebüz } \\
\text { Çün o mihrüñ na'lininde kebkebüz } \\
\text { Mihr [ü] mehden sa'd-i rūşen kevkebüz }\end{array}$ \\
\hline 074 . & $215^{\mathrm{a}}$ & $\begin{array}{l}\text { Çünki faḳr u fāḳa ile rāḥatuz } \\
\text { Ol sebebden her dem ehl-i șūretüz } \\
\text { Șūret-i Raḥmān'a ḥayrān olmışuz } \\
\text { Bizi șanmañ mest-i ehl-i şöhretüz }\end{array}$ \\
\hline 075. & $215^{a}$ & $\begin{array}{l}\text { Biz ki ol baḥrī vü baḥr-i vaḥdetüz } \\
\text { Her dem ol deryāda garkạ-ı ḥayretüz } \\
\text { Māsivāda istivāyı göreli } \\
\text { Bì-gümān bilgil ki ehl-i ru’yetüz }\end{array}$ \\
\hline 076. & $215^{a}$ & $\begin{array}{l}\text { İ țālib bākịilik umma fenāsuz } \\
\text { Fenānuñ hod vücūdıdur bekāāsuz } \\
\text { Vücūd'ullāh olaydı māsivāsuz } \\
\text { Deger kimse sivā Fażl-1 Hudā'suz }{ }^{428}\end{array}$ \\
\hline 077. & $215^{\mathrm{a}}$ & $\begin{array}{l}\text { Kirdigāruñ nuț̣ıına hāmil bizüz } \\
\text { Aña ‘ālem olmasaḳ cāhil bizüz } \\
\text { Kīmyā-yı cāna çün vāṣıl bizüz } \\
\text { Bil bu sırrı bilmesek vāṣıl bizüz }\end{array}$ \\
\hline
\end{tabular}

\footnotetext{
${ }^{427}$ Dizelerde vezin değişiyor. 1. ve 3. dizelerde vezin: fâilâtün fâilâtün fâilün; 2. ve 4. dizelerde vezin: mefâilün mefầllün feûlün.

${ }^{428}$ mefầllün mefầllün feûlün.
} 


\begin{tabular}{|c|c|c|}
\hline 078. & $215^{\mathrm{a}}$ & $\begin{array}{l}\text { Her nefes menzil-be-menzil göçerüz } \\
\text { Gün bugün nice olursa giçerüz } \\
\text { Çün müdām vahdet meyinden içerüz } \\
\text { Ehl-i şirküñ kevşerinden ḳaçaruz }\end{array}$ \\
\hline 079. & $215^{\mathrm{b}}$ & $\begin{array}{l}\text { Gel beru gevher-şinās ol çün ayaz } \\
\text { Gevheri tanı ḥakīkat ne mecāz } \\
\text { Gevheri bil gevheri bul gevheri } \\
\text { Gevheri bilendür olan şāhbāz }\end{array}$ \\
\hline \multicolumn{3}{|r|}{ Ḥarfü'ş-Şīn } \\
\hline 080. & $215^{\mathrm{b}}$ & $\begin{array}{l}\text { Devlet içün ḳoymayan meydāna baş } \\
\text { Beglük alup olmadı ‘alemde baş } \\
\text { Er gerek erlik güninde ad ala } \\
\text { Ḳlıcuñ ḳarşular içinde savaş }\end{array}$ \\
\hline 081. & $216^{a}$ & $\begin{array}{l}\text { Bil ki ādem maẓharı Allāh imiş } \\
\text { Vechi anuñ Haḳk'a țog̀rı rāh imiş } \\
\text { Çün bu sırra enbiyā āgāh imiş } \\
\text { Bilmeyen dīv 'āṣi vü gümrāh imiş }\end{array}$ \\
\hline 082. & $216^{a}$ & $\begin{array}{l}\text { Fażl[1] bilen sırr-1 Fażlu'llāh imiş } \\
\text { Aḥmed ü Ādem'den ki ol āgāh imiş } \\
\text { 'Ayn lām ye ma'nīde çün şāh imiş } \\
\text { İşbu remzi añlayan Allāh imiş }\end{array}$ \\
\hline 083. & $216^{a}$ & $\begin{array}{l}\text { Cümle eşyā Muṣhhaf-1 āyāt imiş } \\
\text { Ol ṣıfāt-imiş vücūduñ zāāt imiş } \\
\text { Ger 'Arab ger Hind ger Türk Tāt imiş } \\
\text { Yüzlerinde sì vü dü āyāt imiş }{ }^{429}\end{array}$ \\
\hline 084. & $216^{\mathrm{a}}$ & $\begin{array}{l}\text { Yārumuñ gül tek yañag̉ı ay imiş } \\
\text { Gör ki hūblar arasında bay imiş } \\
\text { Yüzi nakşıı ebced ü țāhā imiş } \\
\text { Kara șaçı leyletü̈l-isrā imiş }\end{array}$ \\
\hline
\end{tabular}

${ }^{429}$ 3. misrada vezin aksiyor. 


\begin{tabular}{|c|c|c|}
\hline 085. & $216^{\mathrm{a}}$ & $\begin{array}{l}\text { Ādemīye ma'rifet hoş tāc imiş } \\
\text { Salțanatla māl ü mülk ü bāc imiş } \\
\text { Ma'rifetsüz ādemì muḥtāc imiş } \\
\text { ‘Álem anuñ olsa ḳarnı aç imiş }\end{array}$ \\
\hline 086. & $216^{\mathrm{b}}$ & $\begin{array}{l}\text { Bil bu ādem Haḳ'dan ulu ad imiş } \\
\text { Ka'betu'llāh hayme-i mī‘ād imiş } \\
\text { Çün Melik Şākir'dür ol üstād imiş } \\
\text { Ma'rifet bu yolda gayet zād imiş }\end{array}$ \\
\hline 087. & $216^{b}$ & $\begin{array}{l}\text { Çünki vāḥidden sivā īcād imiş } \\
\text { Bu sivā hod ser-be-ser bir ad imiş } \\
\text { Kim bu sırrı bilse dā'im şād imiş } \\
\text { Ġușṣasından dünyenüñ āzād imiş }\end{array}$ \\
\hline 088. & $216^{\mathrm{b}}$ & $\begin{array}{l}\text { ‘Āşık [u] ma'şūḳ kadīmī yār imiş } \\
\text { Sırr-1 ẓāhir bilmeyen ag̉yār imiş } \\
\text { Bu Nesīmí'nüñ çün ol dildār imiş } \\
\text { Niçe dildār ḳamu andan var imiş }{ }^{430}\end{array}$ \\
\hline \multicolumn{3}{|r|}{ Harfüi'ṭ-Ṭā } \\
\hline 089. & $217^{\mathrm{b}}$ & $\begin{array}{l}\text { Vechinüñ levhịindedür sī vü dü haṭ } \\
\text { ‘Aşḳınuñ deryāsına düş hem-çü baṭ } \\
\text { Gel oḳı yüzinde ag u ḳara hat } \\
\text { Uşta gör fi șūretin emred ḳıțat }\end{array}$ \\
\hline \multicolumn{3}{|r|}{ Harfü'l-Fā' } \\
\hline 090. & $218^{\mathrm{a}}$ & $\begin{array}{l}\text { Șāf-dil ol ṣūfiyā sen urma lāf } \\
\text { Kūşe-i meyhānede it i'tikāf } \\
\text { Şol perī meh-rūy[1] it her dem țavāf } \\
\text { Fażl-1 raḥmet bì-kerāndur lā-tahāf }\end{array}$ \\
\hline
\end{tabular}

${ }^{430}$ İlk iki mısra Ayan neşrinde 3. ve 4. mısra olarak yer almaktadır; diğer iki mısra farklıdır. 


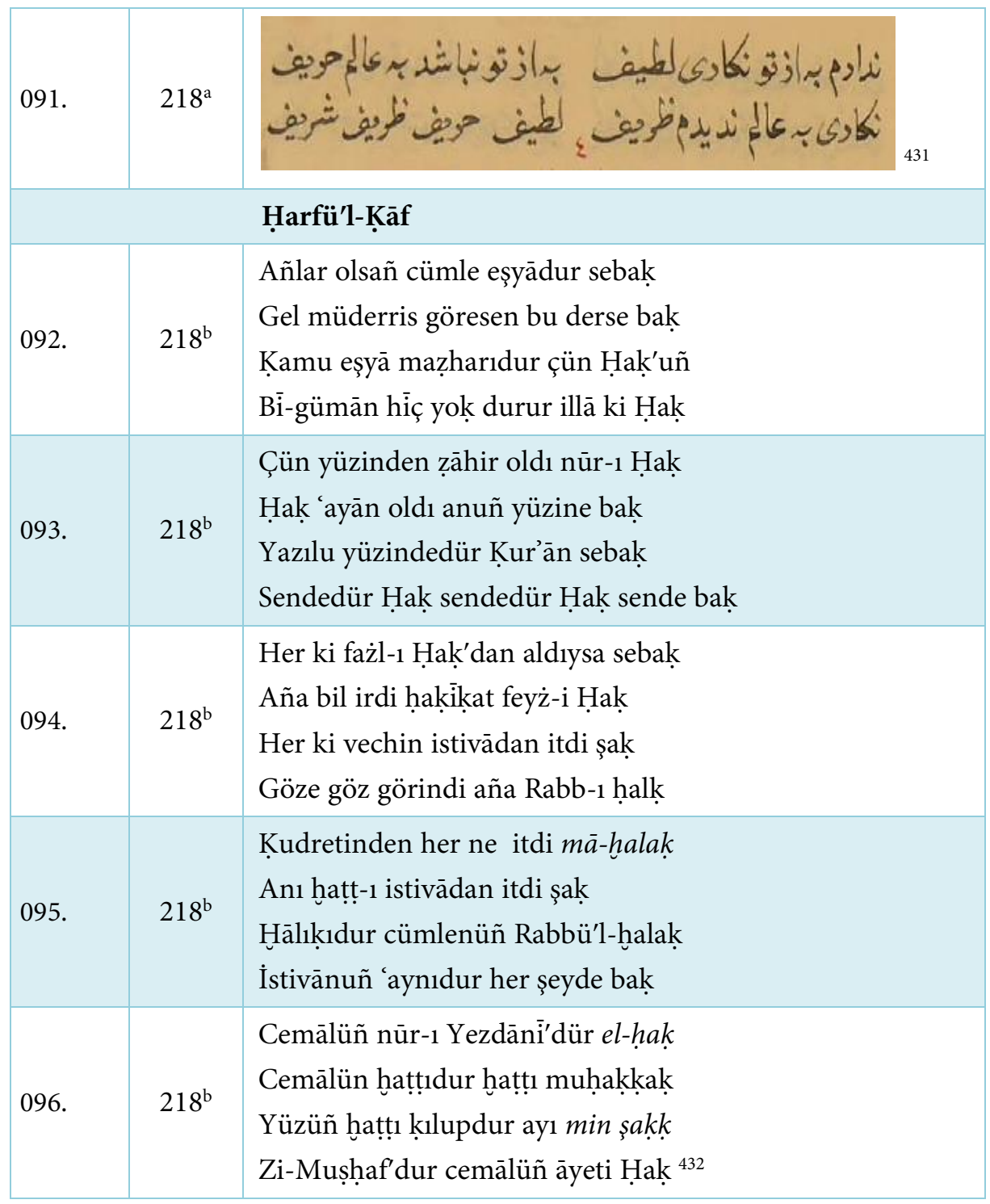

\footnotetext{
${ }^{431}$ Farsça tuyuğ. feûlün feûlün feûlün feûl

Nedārem beh ez-to nigāīi lațîf / Beh ez-to nebāşed be-ālem harīif

Nigāri be-ālem nedīem ẓarif / Lațif-i hạaîf-i ẓarif-i şerif

${ }^{432}$ mefâillün mefầllün feûlün
} 


\begin{tabular}{|c|c|c|}
\hline 097. & $218^{\mathrm{b}}$ & $\begin{array}{l}\text { Bu nüh țāḳı ki gördüñ oldı ezraḳ } \\
\text { Döner țurmaz gice gündüz mu'allaḳ } \\
\text { Nedür makṣūdı bildüñ mi ey aḥmaḳ } \\
\text { Hemān bil bü'l-beşerden feyż ider Hạạ }{ }^{433}\end{array}$ \\
\hline 098. & $218^{\mathrm{b}}$ & $\begin{array}{l}\text { Ey iki ḳaşuñ iki ‘ālemde țāk } \\
\text { Leblerüñ şānındadur ke’sen dihāk } \\
\text { Āb-1 hạayāndur lebüñ aldum sorak } \\
\text { Düşdi hüsnüñden cihāna bi'l-ġalāk }\end{array}$ \\
\hline 099. & $219^{\mathrm{a}}$ & $\begin{array}{l}\text { Bizüz ol pervāne kim pervāsı yoḳ } \\
\text { Yaḳmışuz ser şem ‘a] dest [u] pāsı yoḳ } \\
\text { İderüz Allāhu illā lāsı yoḳ } \\
\text { Cān [u] göñlüñ andan artuḳ pāsı yoḳ }\end{array}$ \\
\hline 100. & $219^{a}$ & $\begin{array}{l}\text { Her kimüñ ki çehresinde zerdi yoḳ } \\
\text { 'Aş̧̣ odından cān içinde derdi yoḳ } \\
\text { 'Āşıkunun çün kim bir āh-1 serdi yoḳ } \\
\text { Ma şūụuñ bāġında anuñ verdi yoḳ }\end{array}$ \\
\hline \multicolumn{3}{|r|}{ Ḥarfü'l-Kāf } \\
\hline 101. & $219^{\mathrm{b}}$ & $\begin{array}{l}\text { Sì vü dünüñ 'alā’imidür yüzüñ } \\
\text { Ka'benüñ beytü'l-harāmmıdur yüzüñ } \\
\text { Sī vü düden [bil]nişānīiür yüzüñ } \\
\text { Mihrü māhuñ armaġanıdur yüzüñ }\end{array}$ \\
\hline 102. & $220^{\mathrm{a}}$ & 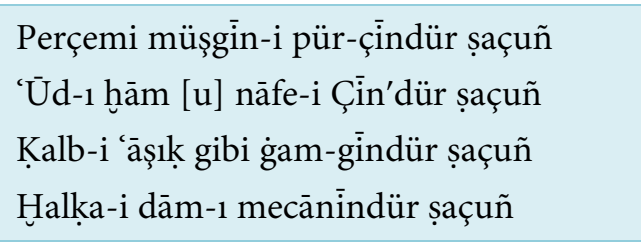 \\
\hline 103. & $220^{\mathrm{b}}$ & $\begin{array}{l}\text { Ey elif ḳaddüñe lām oldı ṣaçuñ } \\
\text { Et-tahiyyaāt es-selām oldı șaçuñ } \\
\text { Gerçi kim sevdā-yı hām oldı ṣaçuñ } \\
\text { Cümle-i ervāḥa dām oldı ṣaçuñ }\end{array}$ \\
\hline
\end{tabular}

${ }^{433}$ mefâillün mefầllün feûlün 


\begin{tabular}{|c|c|c|}
\hline 104. & $220^{\mathrm{b}}$ & $\begin{array}{l}\text { Çün hüden li'l-müttakīn oldı șaçuñ } \\
\text { 'Āşı1ka hablü'l-metīn oldı șaçuñ } \\
\text { İ'tiḳād ehline dīn oldı șaçuñ } \\
\text { Huām-1 'anber misk-i Çīn oldı șaçuñ }\end{array}$ \\
\hline 105. & $220^{\mathrm{b}}$ & $\begin{array}{l}\text { Firḳatinden yandı bu cān zülfünüũn } \\
\text { Hasretinden dil perişāan zülfünüün } \\
\text { Rūz [u] şeb zulmetde ḳaldum ölürem } \\
\text { Mihr ü māh ebrinde pinhān zülfüñüñ }\end{array}$ \\
\hline 106. & $220^{\mathrm{b}}$ & $\begin{array}{l}\text { Key mu'allā țāḳ olupdur ḳaşlaruñ } \\
\text { Ḳıble-i ‘uşşạ̣ olupdur ḳaşlaruñ } \\
\text { Çünki hūb aḩlāḳ olupdur ḳaşlaruñ } \\
\text { Cānlara missāạ olupdur ḳaşlaruñ }\end{array}$ \\
\hline 107. & $220^{\mathrm{b}}$ & $\begin{array}{l}\text { Fitne-engīz-i cihāndur gözlerüñ } \\
\text { Huavf-1 ‘aḳl u sīm-i cāndur gözlerüñ } \\
\text { Bir siyeh-dil pehlevāndur gözlerüñ } \\
\text { Ḩalḳ șanur kim nā-tuvāndur gözlerüñ }\end{array}$ \\
\hline 108. & $221^{\mathrm{a}}$ & $\begin{array}{l}\text { Eyledi bag̉rumda uş yara gözüñ } \\
\text { Zülfüñe çekdi beni dāra gözüñ } \\
\text { Göñlümi eyledi āvāre gözüñ } \\
\text { Urġun itdi Çīn [ü] Tatar'a gözüñ }\end{array}$ \\
\hline 109. & $221^{a}$ & $\begin{array}{l}\text { Gör ne luțf [u] i tibār eyler gözüñ } \\
\text { Çeşmümi kevşer-nişār eyler gözüñ } \\
\text { Göñlüm ile gīr ü dār eyler gözüñ } \\
\text { Āhū-yı Çīin'i şikār eyler gözüñ }\end{array}$ \\
\hline 110. & $221^{a}$ & $\begin{array}{l}\text { Selsebīle sākēi oldı leblerüñ } \\
\text { Hem dilüñ müştāḳı oldı leblerüñ } \\
\text { Bir şarāb-ı bākī oldı leblerüñ } \\
\text { Cānlaruñ rezzāḳı oldı leblerüñ }\end{array}$ \\
\hline
\end{tabular}




\begin{tabular}{|c|c|c|}
\hline 111. & $221^{\mathrm{b}}$ & 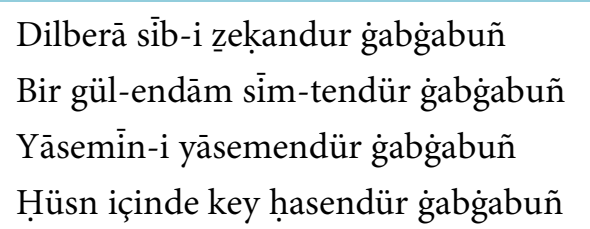 \\
\hline 112. & $222^{\mathrm{a}}$ & $\begin{array}{l}\text { Añla kim Fażl-1 Hudā'dur șūretüñ } \\
\text { Ka‘be-i ehl-i șafādur șūretüñ } \\
\text { Cānlara cām-1 beḳādur șūretüñ } \\
\text { Gör ne șāfì hạak-nümādur șūretüñ }\end{array}$ \\
\hline 113. & $222^{\mathrm{a}}$ & $\begin{array}{l}\text { [Bil ki] Fażlu'llāhu Raḥmāndur yüzüñ } \\
\text { Oḳudum āyāt-ı Kurư̄ān'dur yüzüñ } \\
\text { İncil ü Tevrāt u Ḳurāān'dur yüzüñ } \\
\text { Halkạa bì-şek hāṣṣ-1 burhāndur yüzüñ }\end{array}$ \\
\hline 114. & $222^{\mathrm{a}}$ & $\begin{array}{l}\text { Āfitāb-1 mațla'-1 cāndur yüzüñ } \\
\text { Rūşen oldı̄ nūr-1 Yezdān'dur yüzüñ } \\
\text { Çün murād-1 kuțb-1 devrāndur yüzüñ } \\
\text { Mihr-i ālem māh-ı tābāndur yüzüñ }\end{array}$ \\
\hline 115. & $222^{\mathrm{a}}$ & $\begin{array}{l}\text { Cennet-i 'Adn șıāṭ oldı yüzüñ } \\
\text { Menba'-1 'ayş-1 neşāṭ oldı yüzüñ } \\
\text { Hem muhịị u hem muhāṭ oldı yüzüñ } \\
\text { Çünki hạarf-ile niḳāṭ oldı yüzüñ }\end{array}$ \\
\hline 116. & $222^{\mathrm{b}}$ & $\begin{array}{l}\text { Ālemi ḳıldı münevver ay yüzüñ } \\
\text { Cān elin yaġmāladı cādū gözüñ } \\
\text { Țudagiuñ ister harācın Hürrmüz'üñ } \\
\text { Sükkeri eyler ḩacīl şīiñ sözüñ }\end{array}$ \\
\hline 117. & $222^{\mathrm{b}}$ & $\begin{array}{l}\text { Ka`be'dür yüzüñ țavāf ider melek } \\
\text { Kand-i la'lüñnden umar kevšer dilek } \\
\text { ‘Ālemüñ şavḳı ruhuñ̃dur bī-terek } \\
\text { Ṭapuña kemter kemíndür nüh felek }\end{array}$ \\
\hline
\end{tabular}




\begin{tabular}{|c|c|c|}
\hline 118. & $222^{\mathrm{bh}}$ & $\begin{array}{l}\text { Ālemüñ ḳavs-i hilālidür ḳaşuñ } \\
\text { Fitnenüñ 'ayn-1 le’ālidür ḳaşuñ } \\
\text { Kābe ḳavseynüñ mis̄ālidür ḳaşuñ } \\
\text { Müşriküñ dā’im zevālidür ḳaşuñ }\end{array}$ \\
\hline 119. & $222^{\text {bh }}$ & $\begin{array}{l}\text { Levhh-i maḥfūz-ile Kur’ān'dur yüzüñ } \\
\text { Hāàkim-i hükm-ile devrāndur yüzüñ } \\
\text { Ṣūret-i Raḥmān'a burhāndur yüzüñ } \\
\text { 'Āşıkuñ dīn-ile ìmāndur yüzüñ }\end{array}$ \\
\hline 120. & $223^{\mathrm{a}}$ & $\begin{array}{l}\text { Ṭarìkınca giderseñ şems-i dīnüñ } \\
\text { Senüñ feyyāż ola dā’im mu 'īnüñ } \\
\text { İşit gel sözini Rūhu'l-emīn'üñ } \\
\text { Kelāmu'llāh ol[a] nūr-1 mübīnüñ }{ }^{434}\end{array}$ \\
\hline 121. & $223^{\mathrm{a}}$ & $\begin{array}{l}\text { Her kime kim ‘aşḳı hem-rāh eyledüñ } \\
\text { Gice gündüz işini āh eyledüñ } \\
\text { Bir tecellī aña nāgāh eyledüñ } \\
\text { Dü cihāndan anı āgāh eyledüñ }\end{array}$ \\
\hline \multicolumn{3}{|r|}{ Ḥarfü'l-Lām } \\
\hline 122. & $225^{\mathrm{a}}$ & $\begin{array}{l}\text { Mā-siva'llāh ṣūfiyā oldı hayāl } \\
\text { Sözi çog idüp uzatma ḳıyl u kēāl } \\
\text { Ġayr-ı Ḥaḳ olmaḳ muhāl oldı muhāl } \\
\text { Çünki Ḥaḳ'dur bì-mis̄āl ü bì-zevāl }\end{array}$ \\
\hline 123. & $225^{\mathrm{a}}$ & 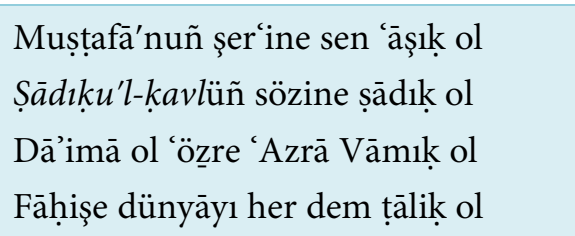 \\
\hline 124. & $225^{a}$ & $\begin{array}{l}\text { ‘Ālem-i faḳr-ı fenāda fānī ol } \\
\text { On sekiz biñ ‘ālemüñ sulțānı ol } \\
\text { Geç hevā-yı nefsden rūḥāni ol } \\
\text { Cümle cismüñ sen hạạịat cānı ol }\end{array}$ \\
\hline
\end{tabular}

434 "șemsü'd-dīn" vezin gereği "sems-i dīn" yazıldı. mefâîlün mefâîlün feûlün. 


\begin{tabular}{|c|c|c|}
\hline 125. & $225^{\mathrm{a}}$ & 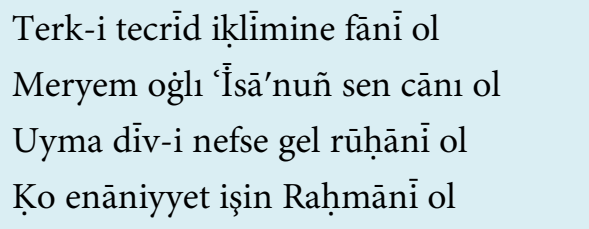 \\
\hline 126. & $225^{\mathrm{a}}$ & $\begin{array}{l}\text { Bende-i feyyāż-1 fażl u Hāāık ol } \\
\text { Şāh-1 cān ol cismü 'abden 'āşı̣ ol } \\
\text { Otuz iki nuțka dā’im nāț̣k ol } \\
\text { Kāri-i ḥubbü'n-nevāda Ḩālı̣ ol }\end{array}$ \\
\hline 127. & $225^{\mathrm{a}}$ & $\begin{array}{l}\text { Şol kişi kim mest-i şehvet oldı ol } \\
\text { Sen yaḳīn bil ehl-i la'net oldı ol } \\
\text { Çün hevā-yı nefse ragibet oldı ol } \\
\text { Gitdi hayrı 'ayn-1 şirret oldı ol }\end{array}$ \\
\hline 128. & $225^{\mathrm{a}}$ & $\begin{array}{l}\text { Her ki Fażl'uñ 'ilmine ḳā’il degül } \\
\text { Min ledün 'ilmi aña hāṣı̣l degül } \\
\text { Her ki maḥbūb-ṣūrete mā’il degül } \\
\text { Vech-i Ḥaḳk'a tā-ebed vāṣıl degül }\end{array}$ \\
\hline 129. & $225^{\mathrm{b}}$ & $\begin{array}{l}\text { Sendedür şol nūr-1 Allāh ey göñül } \\
\text { Ḥaḳk'a ṭoginıdur saña rāh ey göñül } \\
\text { Çünki Ḥak'dur lem-yezel şāh ey göñül } \\
\text { Vāḳı ol Ḥaḳ'dan hem āgāh ey göñül }\end{array}$ \\
\hline 130. & $225^{\mathrm{b}}$ & $\begin{array}{l}\text { Gözlerüñ alasına virdüm göñül } \\
\text { Kaş̧laruñ ḳarasına virdüm gönüul } \\
\text { Zülfüñuñ gaamzesine virdüm göñül } \\
\text { Kāmet-i bālāsına virdüm göñül }\end{array}$ \\
\hline 131. & $225^{\mathrm{b}}$ & $\begin{array}{l}\text { Hoḳka-i lü’lü'-i lālādur göñül } \\
\text { Cevher-i zāāt-1 mu'allādur göñül } \\
\text { Et-tahịyyāt min müheyyādur göñül } \\
\text { Nūr-1 żāt-1 Ḥaḳ Te ālā'dur göñül }\end{array}$ \\
\hline
\end{tabular}




\begin{tabular}{|c|c|c|}
\hline 132. & $225^{\mathrm{b}}$ & $\begin{array}{l}\text { Hatțt-1 reyhānına hayrāndur göñül } \\
\text { Zülf-i cem inde periş̧āndur gönüul } \\
\text { Gül yüzüñ göreli hanandāndur göñül } \\
\text { Leblerüñden țāibā cāndur göñül }\end{array}$ \\
\hline 133. & $225^{\mathrm{b}}$ & $\begin{array}{l}\text { Göñlüm eydür Haḳk'ı 'ayān eylegil } \\
\text { Kuul iken kendüñi sulțān eylegil } \\
\text { Cān içinde seni sen cān eylegil } \\
\text { Hạạ yüzinde beni ḥayrān eylegil }\end{array}$ \\
\hline 134. & $225^{\mathrm{bh}}$ & $\begin{array}{l}\text { Cāhil-ile țutma iş ādem degül } \\
\text { Diyüdur cāhil ki hīç ādem degül } \\
\text { Luṭ̂ı yoḳdur cāhilüñ ādem degül } \\
\text { Cāhile ādem diyen ādem degül }\end{array}$ \\
\hline 135. & $226^{\mathrm{a}}$ & $\begin{array}{l}\text { Sözi gāyet fikr idüp derk eylegil } \\
\text { Şol menāhī işleri terk eylegil } \\
\text { Cān evāmir olana berk eylegil } \\
\text { Zerḳ u fisḳa tevbeden örk eylegil }\end{array}$ \\
\hline 136. & $226^{\mathrm{a}}$ & $\begin{array}{l}\text { Vech-i ādem vech-i Raḥmān oldı bil } \\
\text { Her kim itmez secde şeyțān oldı bil } \\
\text { Ādemi sen fażl-ı Yezdān oldı bil } \\
\text { Ay-ile gün şāh-ı sulțān oldı bil }\end{array}$ \\
\hline 137. & $226^{\mathrm{a}}$ & $\begin{array}{l}\text { Kanı bir pāk-i'tiḳād u ṣâa-dil } \\
\text { K'işide cāndan bu dem evṣāf-ı dil } \\
\text { Er olanda bil kim olmaz lāf dil } \\
\text { Dir ki sīmurg oldı kūh-ı Ḳāf dil }\end{array}$ \\
\hline 138. & $226^{\mathrm{a}}$ & $\begin{array}{l}\text { Yahşılıḳdur kim ider āzād ḳul } \\
\text { Yahşılı̣̣dan eyledi sözi kabūl } \\
\text { Yahşılıḳdan kim ki yüz döndürmedi } \\
\text { Yahşıllı̣lan kāàim olur her uṣūl }\end{array}$ \\
\hline
\end{tabular}




\begin{tabular}{|c|c|c|}
\hline 139. & $226^{a}$ & $\begin{array}{l}\text { Ma'rifetdür țālibā hayru'l-emel } \\
\text { Anı kesb it olmaġıl bel hüm eḍall } \\
\text { Bil ḳażā ile ḳader hem 'aḳd u hạall } \\
\text { Ol Huudā'dan ṣādır olan bì-'alel }\end{array}$ \\
\hline 140. & $226^{\mathrm{b}}$ & $\begin{array}{l}\text { Her kimüñ 'aḳlında olmaya halel } \\
\text { Ol yaḳiñ ider ki bu cümle milel } \\
\text { Huayr u şer sehv ü hațā ile żilel } \\
\text { Ișț1lāḥ-1 'ām oldı fi'l-meșel }\end{array}$ \\
\hline 141. & $226^{\mathrm{b}}$ & $\begin{array}{l}\text { Çünki Haḳ'dur her ne var evvel ezel } \\
\text { Pes aña nice bulursan di bedel } \\
\text { Yog̀-ise 'aynuñda sālik ger sebīl } \\
\text { Gör ki ma'şūḳa bu cān oldı mahal }\end{array}$ \\
\hline 142. & $226^{\mathrm{b}}$ & $\begin{array}{l}\text { Çün tecellī itdi feyyāż-ı ezel } \\
\text { Māsivāda ḳalmadı gayra maḥal } \\
\text { Mülk anuñ oldı hakịiḳat bì-'alel } \\
\text { Bāḳi ancaḳ kendi ḳaldı lem-yezel }\end{array}$ \\
\hline \multicolumn{3}{|r|}{ Harfü'l-Mīm } \\
\hline 143. & $228^{b}$ & $\begin{array}{l}\text { Hũāce-i dünyā vü dīn kuṭ̣-1 imām } \\
\text { Murteżādur müctebādur ey gulām } \\
\text { Evliyā silkine zīverdür tamām } \\
\text { Huānedāndan cān-perverdür tamām }\end{array}$ \\
\hline 144. & $228^{\mathrm{b}}$ & $\begin{array}{l}\text { Min-ledün 'ilminden işit bir kelām } \\
\text { 'Aḳluñı bu naḳle iş it ey gulām } \\
\text { Bil makāmātuñ tamāmını tamām } \\
\text { Bildigũñden șoñra bilme } v e \text { 's-selām }{ }^{435}\end{array}$ \\
\hline
\end{tabular}

${ }^{435}$ 144/4 "bildigüñden" öreneğinde olduğu gibi yazmada ikinci şahıs iyelik eki yer yer kef (ك) harfi yerine nun (ن) harfi ile yazılmıştır. Transkribe edilmiş metinde bu durum düzeltilmiştir. 


\begin{tabular}{|c|c|c|}
\hline 145. & $229^{a}$ & $\begin{array}{l}\text { Ögredenler diline ādi kelām } \\
\text { Devlet iḳ̣imine țutdılar makāām } \\
\text { Buldılar nār-ı cehennemden necāt } \\
\text { Gördiler dīdārını dārü's-selām }\end{array}$ \\
\hline 146. & $229^{\mathrm{a}}$ & $\begin{array}{l}\text { Her nefes ol dilbere ben hādimem } \\
\text { Lāt'um oldur her dem aña sācidem } \\
\text { İşiginde mu'tekif bir 'ābidem } \\
\text { Gāh fāsılk gāh şeyh-i 'ābidem }\end{array}$ \\
\hline 147. & $229^{a}$ & $\begin{array}{l}\text { Her zamān kim derd-ile yā hū direm } \\
\text { Gayr-1 Haḳk lā vü illā hū direm } \\
\text { Cümle Haḳ'dur her ki var ol bu direm } \\
\text { Ḥaḳ söz işit gel sen iy meh-rū direm }\end{array}$ \\
\hline 148. & $229^{\mathrm{b}}$ & 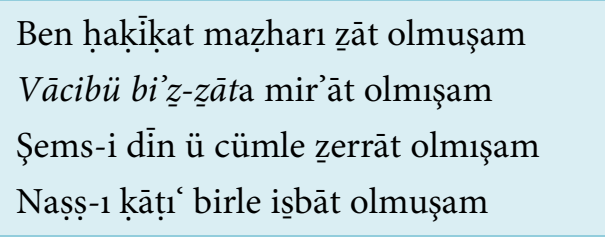 \\
\hline 149. & $229^{\mathrm{b}}$ & $\begin{array}{l}\text { Perdelü bir dilbere zār olmuşam } \\
\text { ‘Aşk dāmında giriftār olmışam } \\
\text { Raḥm ḳıl ey dilber-i bī-merḥamet } \\
\text { Çün esīīin çār nāçār olmışam }\end{array}$ \\
\hline 150. & $229^{\text {bh }}$ & $\begin{array}{l}\text { Görmeyince seni ey cān gözlerüm } \\
\text { Dā’im olur zār u giryān gözlerüm } \\
\text { Neylesün çünkim bu hayrān gözlerüm } \\
\text { Sende gördi nūr-1 Raḥmān gözlerüm }\end{array}$ \\
\hline 151. & $230^{\mathrm{a}}$ & $\begin{array}{l}\text { Ben ki ferdā günin imrūz itmişem } \\
\text { Vech-i yārı 'iyd-ı nevrūz itmişem } \\
\text { Çünki derd-i āh-ile söz itmişem } \\
\text { Āhum odın 'ālem-efrūz itmişem }\end{array}$ \\
\hline
\end{tabular}




\begin{tabular}{|c|c|c|}
\hline 152. & $230^{\mathrm{a}}$ & $\begin{array}{l}\text { Tā temennā-yı viṣālüñ itmişem } \\
\text { Her zamān fikr-i ḩayālüñ itmişem } \\
\text { Eglenem direm ḩayālüñle senüñ } \\
\text { Ben anı def -i melālüñ itmişem }\end{array}$ \\
\hline 153. & $230^{\mathrm{a}}$ & $\begin{array}{l}\text { Fürḳatüñden gör ne hāle dönmüşem } \\
\text { Gözlerüñ alından āle düşmüşem } \\
\text { Çarḩ elinden māh u sāle düşmüşem } \\
\text { Münker ile ḳıyl u kāle düşmüşem }\end{array}$ \\
\hline 154. & $230^{a}$ & $\begin{array}{l}\text { Göñlümi ol yüze hayrān ḳılmışam } \\
\text { Șūretüñ naḳşında seyrān ḳılmışam } \\
\text { Gör bu halk yüzinde pinhān ḳılmışam } \\
\text { Cānumuñ şehrinde sulțān ḳılmışam }{ }^{436}\end{array}$ \\
\hline 155. & $230^{\mathrm{a}}$ & $\begin{array}{l}\text { Benüm vaḥdetdedür yār-ile işüm } \\
\text { Olur keșretde ağyār-ile n'işim } \\
\text { Ola mı açıra yesāra vaḥdet } \\
\text { 'Aceb bilsevüz ey yādı bilişim }\end{array}$ \\
\hline 156. & $230^{\mathrm{a}}$ & 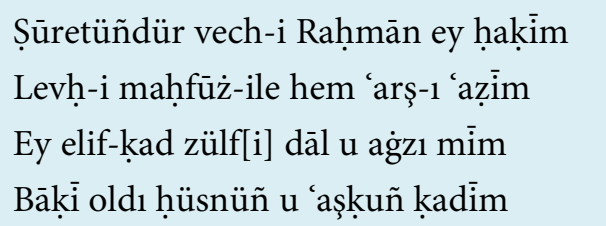 \\
\hline 157. & $230^{\mathrm{b}}$ & $\begin{array}{l}\text { Gice mi var ṣubha dek āh itmeyem } \\
\text { Gusșṣasın cān mülkine şāh itmeyem } \\
\text { Ol yār incindüm dimiş āh itmesün } \\
\text { Aġlayam şimden girü āh itmeyem }\end{array}$ \\
\hline 158. & $230^{\mathrm{b}}$ & $\begin{array}{l}\text { Leblerüñ şerbetini nūş eyledüm } \\
\text { Hem ene'l-ḥak sırrını fāş eyledüm } \\
\text { Otuz iki dürlüden aş eyledüm } \\
\text { Ben fedā Hak yolına baş eyledüm }{ }^{437}\end{array}$ \\
\hline
\end{tabular}

\footnotetext{
${ }^{436}$ 159/2 naḳşında: nefsinde ŞR.

${ }^{437}$ Tuyuğ'un 3. ve 4. mısraları M. Fatih Köksal neşrinde yer alan 23. tuyuğun 2. ve 3. mısraıdır. 1. ve 4. mısralar farklllık göstermektedir. Bkz. Köksal (2000), s. 195.
} 


\begin{tabular}{|c|c|c|}
\hline & & Ḥarfü'n-Nūn \\
\hline 159. & $232^{\mathrm{a}}$ & $\begin{array}{l}\text { Ben vücūd-ı muṭlaḳ oldum bī-gümān } \\
\text { Tā ebed ḥayy ü ḳadīm ü cāvidān } \\
\text { Kirpügi zülfi ḳaşı virdi nişān } \\
\text { Kim yüzüñndür 'arş u kürsì cāna cān }\end{array}$ \\
\hline 160. & $232^{\mathrm{a}}$ & $\begin{array}{l}\text { Dir ḳıyāmet ḳaddüñi gören revān } \\
\text { Kim belā durur belā-yı nāgehān } \\
\text { Rāst tīir-i kaddüñe heft āsumān } \\
\text { İrmek içün egilüp olur kemān }\end{array}$ \\
\hline 161. & $232^{\mathrm{a}}$ & $\begin{array}{l}\text { Ey boyı serv-i ḩıāmān ḳandasan } \\
\text { Ṭūṭi-i la‘l-i Bedahşs̄ān ḳandasan } \\
\text { Gel getür derdüme dermān ḳandasan } \\
\text { Ṭal'atuñdur māh-1 tābān ḳandasan }\end{array}$ \\
\hline 162. & $232^{\mathrm{a}}$ & $\begin{array}{l}\text { Server-i sulțān-1 ālemsen bugün } \\
\text { Ser-firāz-1 şāh-1 ādemsen bugün } \\
\text { Ḥükmüñe fermān Süleymān tek cihān } \\
\text { Ṣāhib-i ạ̣kām u hātemsen bugün }\end{array}$ \\
\hline 163. & $232^{\mathrm{a}}$ & $\begin{array}{l}\text { Va'de-i rūz-1 ḳıyām oldı bugün } \\
\text { Fā vü żād u lām imām oldı bugün } \\
\text { Şol kişi kim kendüyi tanımadı } \\
\text { Her mübāḥ aña ḥarām oldı bugün }\end{array}$ \\
\hline 164. & $232^{\text {ah }}$ & $\begin{array}{l}\text { Aḳıdalı gözlerümden yaşı ben } \\
\text { Ḳomışam yāruñ yolına başı ben } \\
\text { Yāruma ḳașd idene ḳaṣd iderem } \\
\text { Olur-ise ḳo düşümde nāş̧i ben }\end{array}$ \\
\hline 165. & $232^{\mathrm{b}}$ & $\begin{array}{l}\text { Kend'özin șūretde Hak ḳılmış güzīn } \\
\text { Gizlemiş eşyā içinde kend'özin } \\
\text { Perde açmış çāk yüzinden gör özin } \\
\text { Hakaḳ'a ḥaḳ gerek ki göre kend'özin }\end{array}$ \\
\hline
\end{tabular}




\begin{tabular}{|c|c|c|}
\hline 166. & $232^{\mathrm{b}}$ & $\begin{array}{l}\text { Her ki tanıdı o nefs-i ḩilḳatin } \\
\text { Bildi şeksiz vech-i Haḳ'dur șūretin } \\
\text { Kim ḳabūl itdiyse Fażl'uñ da'vetin } \\
\text { Ol ḥaḳiḳat buldı Haḳk'uñ raḥmetin }\end{array}$ \\
\hline 167. & $233^{a}$ & $\begin{array}{l}\text { Münezzehdür yeri gögi yaradan } \\
\text { Kesdi bir ḩırḳa baña çār pāreden } \\
\text { Gerçi oldı hüsnüñüñ adı ulu } \\
\text { Baġrumı ḳıldı bu bahşiş yaralu }{ }^{438}\end{array}$ \\
\hline \multicolumn{3}{|r|}{ Hạfü'l-Hā } \\
\hline 168. & $233^{\text {bh }}$ & $\begin{array}{l}\text { Gülşen oldur ki güli hīç șolmaya } \\
\text { Güzel oldur kavli yalan olmaya } \\
\text { Ölüben 'ahdi bütün bir yār içün } \\
\text { 'Ahdi bütün yār içün kim ölmeye }\end{array}$ \\
\hline 169. & $234^{\mathrm{a}}$ & $\begin{array}{l}\text { Menba'-1 īmān didiler ṣaçuña } \\
\text { Maḳṣad-1 cānān didiler ṣaçuña } \\
\text { Sünbül-i 'irfān didiler șaçuña } \\
\text { Hamse-i erkān didiler șaçuña }\end{array}$ \\
\hline 170. & $234^{\mathrm{a}}$ & $\begin{array}{l}\text { Çün 'ināyet oldı lāyık başuña } \\
\text { And içer cümle halāyık başuña } \\
\text { İrdi Haḳ'dan hem hạakāyık başuña } \\
\text { Gevher-i ma'nā [da] lāyık başuña }\end{array}$ \\
\hline 171. & $234^{\mathrm{a}}$ & $\begin{array}{l}\text { Ey ḳamer māh-1 münevver alnuña } \\
\text { Bende olmuş çarh-ı devver alnuña } \\
\text { Secde eyler şems-i hāver alnuña } \\
\text { Merkez-i ālem müdevver alnuña }\end{array}$ \\
\hline
\end{tabular}

\footnotetext{
438 İlk dizede vezin: mefâ̂ilün mefầlün feûlün; diğer dizelerde: fâilâtün fâilâtün fâilün. Kafiye örgüsü aabb. Dizeler arasındaki vezin ve kafiye örgüsünün düzensizliği manzumenin en az iki farklı şiirin mısralarından oluştuğunu düşündürmektedir.
} 


\begin{tabular}{|c|c|c|}
\hline 172. & $234^{\mathrm{a}}$ & $\begin{array}{l}\text { Cān u göñül țolaşalı zülfüñe } \\
\text { Biñ Süleymān bende düşdi zülfüñe } \\
\text { Yār ene'l-ḥak diyeni dār itdiler } \\
\text { Ben dahı berdār olayın zülfüñe }\end{array}$ \\
\hline 173. & $234^{\mathrm{b}}$ & $\begin{array}{l}\text { Bir güzellik virdi ol Ḥaḳ burnuña } \\
\text { Kim baṣamaz kimse barmaḳ burnuña } \\
\text { Āyine țut yüziñe baḳ burnuña } \\
\text { Gör duṭa mı kimseler daḳk burnuña }\end{array}$ \\
\hline 174. & $234^{\mathrm{b}}$ & $\begin{array}{l}\text { Bir 'acāyib șuṣadı cān la'lüñe } \\
\text { Semme vechu'llāh ey og̀lan la lüñe } \\
\text { Emmege var ise imkān la'lüñe } \\
\text { Ḳıl kerem kim ire insān la'lüñe }\end{array}$ \\
\hline 175. & $234^{\mathrm{b}}$ & $\begin{array}{l}\text { Gerçi şā̄ir āb eydür boynuña } \\
\text { Heykeli aḥbāb eydür boynuña } \\
\text { Zümre-i aṣhāb eydür boynuña } \\
\text { Dir ulu elkāb eydür boynuña }\end{array}$ \\
\hline 176. & $235^{\mathrm{a}}$ & $\begin{array}{l}\text { Kim elifdür didi kim hā boyuña } \\
\text { Men anuñçün düşmüşem ha boyuña } \\
\text { Gün yüzüñ olalı me’vā boyuña } \\
\text { Cān virür ehl-i temāşā boyuña }\end{array}$ \\
\hline 177. & $235^{\mathrm{a}}$ & $\begin{array}{l}\text { 'Ayn u lām u yā durur göñlümde şāh } \\
\text { Yüzi Muṣhaf ḳaşları Haḳ'dur güvāh } \\
\text { Yidi hatțuñdur bize hādī-i rāh } \\
\text { Kim 'ațā ḳıldı bize fażl-1 İlāh }\end{array}$ \\
\hline 178. & $235^{\mathrm{a}}$ & $\begin{array}{l}\text { Çünki oldı hüsnüñe nūr-1 İlāh } \\
\text { Secde eyler vechüñe mihr-ile māh } \\
\text { Senden oldı kimse bulmaz saña rāh } \\
\text { Ḥaḳ kelāmuñdur bu aḥvāle güvāh }\end{array}$ \\
\hline
\end{tabular}




\begin{tabular}{|c|c|c|}
\hline 179. & $235^{a}$ & $\begin{array}{l}\text { Șūretüñ beytü'l-harām oldı bize } \\
\text { Gözlerüñ ni`me'l-imām oldı bize } \\
\text { Kirpügüñ ḳaşuñ kelām oldı bize } \\
\text { Otuz iki ḩaṭ tamām oldı bize }\end{array}$ \\
\hline 180. & $235^{\mathrm{a}}$ & $\begin{array}{l}\text { Ṣūfinüñ destārı bizde bir pile } \\
\text { Bize bir şehbāz gerek ma`nī bile } \\
\text { Bir ḳula kim Hak naẓar ḳılmış ola } \\
\text { Sen aña aṭlas giyür yāhūd pile }\end{array}$ \\
\hline 181. & $235^{\mathrm{b}}$ & $\begin{array}{l}\text { Bülbül-i şūrīdeyem gülzāruña } \\
\text { ‘Āşı̣ oldum lā'l-i şekker-bāruña } \\
\text { Bunca kim cevr eyledüñ sen yāduña } \\
\text { Güle el șunduḳca yanduḳ hāruña }\end{array}$ \\
\hline 182. & $235^{\mathrm{b}}$ & $\begin{array}{l}\text { Şeş cihetden irmişem makssūiduma } \\
\text { İstivādan varmışam ma būduma } \\
\text { Ādemi bildüm ki Fażlullāh imiş } \\
\text { Secde ḳıldum lā-cerem meşhūduma }\end{array}$ \\
\hline 183. & $235^{\mathrm{b}}$ & $\begin{array}{l}\text { Yahşı ol ey dil yamana beñzeme } \\
\text { Șādık ol ehl-i gümāna beñzeme } \\
\text { Hak yolında yoḳdur iki yüzlinüñ } \\
\text { Haḳk'a tọgr'iseñ kemāna beñzeme }\end{array}$ \\
\hline 184. & $235^{\mathrm{b}}$ & $\begin{array}{l}\text { Düşdi göñlüm ġamze-i cādūsına } \\
\text { Cān hedef düşdi kemān ebrūsına } \\
\text { Şāne ursa ‘anberīn gīisūsına } \\
\text { Cān vire 'āşık anuñ ḳohusına }\end{array}$ \\
\hline 185. & $236^{\mathrm{a}}$ & $\begin{array}{l}\text { Şems-i maġrib tọdı 'ālem üstine } \\
\text { Feyż irdi cümle ādem üstine } \\
\text { Baṣma parmaḳ ism-i a'ẓam üstine } \\
\text { Mühr urdı mühr-i hātem üstine }\end{array}$ \\
\hline
\end{tabular}




\begin{tabular}{|c|c|c|}
\hline 186. & $236^{\mathrm{a}}$ & $\begin{array}{l}\text { Düşmüşem mestāne 'aynuñ āline } \\
\text { Al yañagunñdan bu göñlüm alına } \\
\text { Kim ki el eylerse zülfüñ alına } \\
\text { Alına emrinde göñlüm alına }\end{array}$ \\
\hline 187. & $236^{a}$ & $\begin{array}{l}\text { Ḥaḳ hidāyet eyledi luṭf ehline } \\
\text { Kahr olan ḳahr oldı ḳahruñ ḳahrına } \\
\text { Çünki yerci‘ külli şey’in aṣlına } \\
\text { Ehlini ehline cehli cehline }{ }^{439}\end{array}$ \\
\hline 188. & $236^{\mathrm{a}}$ & $\begin{array}{l}\text { Bāg̀g-1 cennet hụūr-1 Rıḍvān fātiḥa } \\
\text { Āb-ı raḥmet nār-ı Yezdān fātiḥa } \\
\text { Her dem oḳı hemçü pīāān fātiḥa } \\
\text { Rūşen oldı çünki og̉lan fātiḥa }\end{array}$ \\
\hline 189. & $236^{\mathrm{a}}$ & $\begin{array}{l}\text { Bize cūdı ḳıldı Sübhān fātiḥa } \\
\text { Cān evine oldı mihmān fātiḥa } \\
\text { Hamdüli'llāh nūr-1 vicdān fātiḥa } \\
\text { Taḩta geldi oldı sulțān fātiḥa }\end{array}$ \\
\hline 190. & $236^{\mathrm{a}}$ & $\begin{array}{l}\text { Ādem'i bil oldı insān fātiḥa } \\
\text { Aña ta 'līm itdi Sübhāān fātiḥa } \\
\text { İrişimez 'aḳla şeyțān fātiḥa } \\
\text { İtdi melek secde cānān fātiḥa }\end{array}$ \\
\hline 191. & $236^{\mathrm{b}}$ & 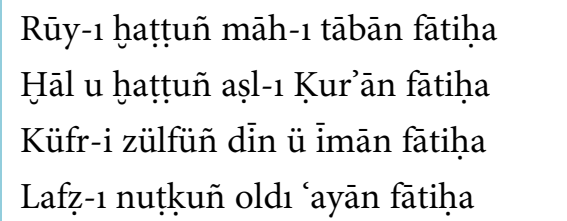 \\
\hline 192. & $236^{\mathrm{b}}$ & $\begin{array}{l}\text { Ṣūretüñdür vech-i Raḥmān fātiḥa } \\
\text { Sīretüñdür Fażl-i Yezdān fātiḥa } \\
\text { Leblerüñdür āb-1 ḥayvān fātiḥa } \\
\text { Her dü ebrū çār müjgān fātiḥa }\end{array}$ \\
\hline
\end{tabular}

${ }^{439}$ 199/4 cehli: cāhil ŞR. 


\begin{tabular}{|c|c|c|}
\hline 193. & $236^{\mathrm{b}}$ & $\begin{array}{l}\text { Yazdı alnuñ üzre Yezdān fātiḥa } \\
\text { İncīl ü Tevrāt u Kur'ān fātiḥa } \\
\text { Fażl-ı bismillāhi'r-raḥmān fātiḥa } \\
\text { Sensen ol her derde dermān fātiḥa }\end{array}$ \\
\hline 194. & $236^{\mathrm{b}}$ & $\begin{array}{l}\text { Āyet-i seb`a'l-meșāni fātiḥa } \\
\text { 'Ālem-i genc-i ma‘ānī fātihāa } \\
\text { Kā’inātuñ cism ü cānı fātiḥa } \\
\text { 'Aşk odınuñ hānümānı fātiḥa }\end{array}$ \\
\hline 195. & $236^{\mathrm{b}}$ & $\begin{array}{l}\text { Gün yüzüñdür cāvidāni fātiḥa } \\
\text { Āyet-i seb`a'l-meșāni fātiḥa } \\
\text { Huaṭ u hālüñdür nişānı fātiḥa } \\
\text { Diyüdür șubḥ ol beyānı fātiḥa }\end{array}$ \\
\hline 196. & $236^{\mathrm{b}}$ & $\begin{array}{l}\text { Olduğıyçün vech-i Raḥmān fātiha } \\
\text { Oldı Haḳ̆dan hūb-ı zībā fātiḥa } \\
\text { Yidi hyaṭdur ümm-i esmā fātiḥa } \\
\text { Dīv-i cāhil bilmez aṣlā fātiḥa }{ }^{440}\end{array}$ \\
\hline 197. & $236^{\mathrm{b}}$ & $\begin{array}{l}\text { Vech-i ādem oldı ey cān fātiḥa } \\
\text { Dīv gözinden oldı pinhān fātiḥa } \\
\text { Cümle ālem oldı yeksān fātiḥa } \\
\text { Göriser mi çeşm-i şeytān fātiḥa }\end{array}$ \\
\hline \multicolumn{3}{|r|}{ Harfü'l-Yā } \\
\hline 198. & $237^{\text {ah }}$ & $\begin{array}{l}\text { Menba'-1 cūd u 'aṭā bil ādemi } \\
\text { Ādeme 'ahd ü vefā bil ādemi } \\
\text { Zāhir ü bāṭın hufāā bil ādemi } \\
\text { Ma'den-i luṭ̂ u sehā bil ādemi }\end{array}$ \\
\hline 199. & $238^{b}$ & 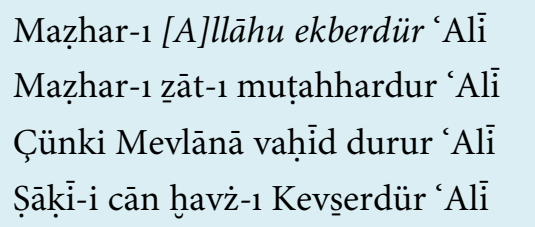 \\
\hline
\end{tabular}

${ }^{440}$ Bu tuyuğun yanına "a ${ }^{a} \bar{a} "$ notu düşülmüşs. 


\begin{tabular}{|c|c|c|}
\hline 200 & $238^{\mathrm{b}}$ & $\begin{array}{l}\text { Nașs-1 kāṭı' birle șaḥh erdür 'Ali } \\
\text { Evliyāya belki rehberdür 'Alī } \\
\text { Enbiyā kātında serverdür 'Alī } \\
\text { Șāhibib-i miḥrāb u minberdür 'Alī }\end{array}$ \\
\hline 201. & $238^{\mathrm{b}}$ & $\begin{array}{l}\text { Muṣhaf-1 cānda mukarrardur 'Ali } \\
\text { Min ledün 'ilmine defterdür 'Ali } \\
\text { Noḳta-i ebced ü mihterdür 'Ali } \\
\text { Bilegör kim tuhfe maẓhardur 'Ali }\end{array}$ \\
\hline 202. & $238^{\mathrm{b}}$ & 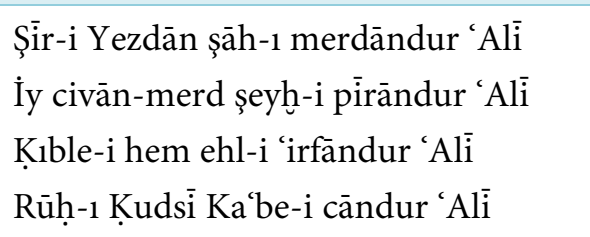 \\
\hline 203. & $239^{a}$ & 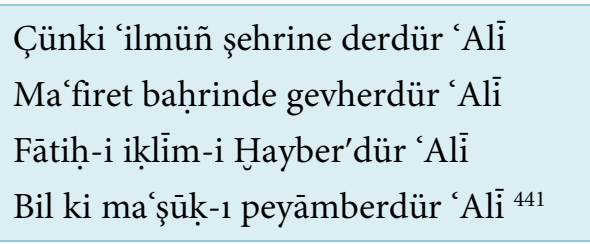 \\
\hline 204. & $239^{a}$ & 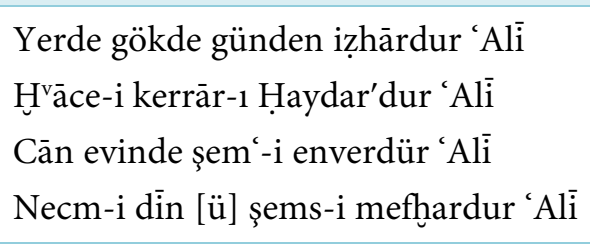 \\
\hline 205. & $239^{a}$ & $\begin{array}{l}\text { Derd-i dilberden beni dūr eyledi } \\
\text { Vuṣlatından cānı mehcūr eyledi } \\
\text { Key şifāsuz derde rencūr eyledi } \\
\text { Luṭf[1] yoḳ ḳahrında maḳhūr eyledi }\end{array}$ \\
\hline 206. & $239^{a}$ & $\begin{array}{l}\text { Her kim ol hüsn-i cemāli sevmedi } \\
\text { Şöyle bil ki Züül-celāl’i sevmedi } \\
\text { Çünki kāāl ehli bu ḥāli sevmedi } \\
\text { Ehl-i vaḥdet ḳıyl u ḳāli sevmedi }\end{array}$ \\
\hline
\end{tabular}

${ }^{441}$ 203/4 "peyġamber" vezin gereği "peyāmber" yazıldı. 


\begin{tabular}{|c|c|c|}
\hline 207. & $239^{\mathrm{a}}$ & $\begin{array}{l}\text { Gözlerüm yaşı muhịịi çaġladı } \\
\text { Seyl olup hicrüñ yolunı baġladı } \\
\text { Āhumuñ derdi cigerler țag̉ladı } \\
\text { Ḥālümi gören kişiler agladı }\end{array}$ \\
\hline 208. & $239^{\mathrm{a}}$ & $\begin{array}{l}\text { Altı günde yaradıldı üç yidi } \\
\text { İstivā geçti sekiz oldı yidi } \\
\text { Ne sebebdendür ki bu üç kez yidi } \\
\text { İstivā geçdi sekiz oldı yidi }{ }^{442}\end{array}$ \\
\hline 209. & $239^{\mathrm{b}}$ & $\begin{array}{l}\text { Șūretüñ Muṣhạf'dur ey ma'nā eri } \\
\text { Oḳı şerh it bil 'arażdan cevheri } \\
\text { Gice gündüz nefs-ile ḥayvān-ṣıfat } \\
\text { Gezmeyesin tā ki şöyle serseri }\end{array}$ \\
\hline 210 & $239^{\mathrm{b}}$ & 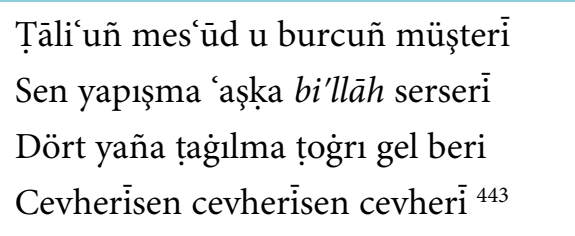 \\
\hline 211. & $239^{\mathrm{b}}$ & $\begin{array}{l}\text { Şehr-i 'ilmüñ çün ‘Alì'dür ḳapusı } \\
\text { Ümmete bizden gerekdür țapusı } \\
\text { Nice perde altına gizlene 'aşḳ } \\
\text { Demidür açlla sırlar ḳapusı }\end{array}$ \\
\hline 212 & $239^{\mathrm{b}}$ & $\begin{array}{l}\text { Fażl-ı Yezdān'uñ yüzüñdür nāmesi } \\
\text { Sī vü dü haṭ oldı ḳudret hāmesi } \\
\text { Bār u hāk u āb u āteș oldı hem } \\
\text { Zāāt-ı Allāh'uñ hạakịkat cāmesi }\end{array}$ \\
\hline 213. & $239^{\text {bh }}$ & $\begin{array}{l}\text { Vech-i ādem bil ki Haḳk'uñ maẓharı } \\
\text { Bilmedi sırrın anuñ dīi [ü] perí } \\
\text { Her ki bu gözgüde gördi dilberi } \\
\text { Māsivā'llāh'dan ḳılupdur dil berī }\end{array}$ \\
\hline
\end{tabular}

${ }_{442}$ 221/2-4 geçdi: geçdik; ŞR.

${ }^{443}$ 223/2 sen: gel; 223/3 tag̉ılma țog̉n gel: tagiıtma 'aḳlın gel; 223/4 cevherisen: cevherī ol; cevherīsen: cevheri bil; ŞR. 


\begin{tabular}{|c|c|c|}
\hline 214 & $239^{\text {bh }}$ & $\begin{array}{l}\text { Dil müselsel zülfünüüñ dīvānesi } \\
\text { Cān cemālüñ şem inüñ pervānesi } \\
\text { 'Așḳ̂ñnuñ cāmın elümden ḳomazam } \\
\text { Tā țolınca ömrümüñ peymānesi }{ }^{444}\end{array}$ \\
\hline 215. & $240^{\mathrm{a}}$ & 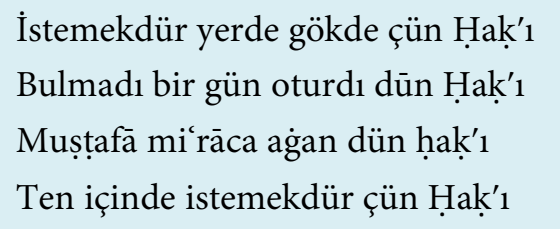 \\
\hline 216. & $240^{\text {ah }}$ & $\begin{array}{l}\text { Ḩaste dil dāru'ş-şifā bil ādemi } \\
\text { Cümle derdlere devā bil ādemi } \\
\text { Huavf-1 cāna sen recā bil ādemi } \\
\text { Hazn-1 Kưr’ān'a revā bil ādemi }\end{array}$ \\
\hline 217 & $240^{\text {ah }}$ & $\begin{array}{l}\text { Ādemi bildüñ dilerseñ ādemi } \\
\text { Ol Huudā'nuñ fażlıdur bil ādemi } \\
\text { Ol durur ‘ilm-i ledünnüñ 'ālemi } \\
\text { Gör nūr-ile rūşen itdi ādemi }\end{array}$ \\
\hline 218. & $240^{\text {ah }}$ & $\begin{array}{l}\text { Çünki țālib bilmez isen àdemi } \\
\text { Bil ki bilmezsin Hudā-yı 'ālemi } \\
\text { Ey faḳīh ü şeyh ü șūfī ādemi } \\
\text { Cehd idegör bil Mesịh-i hem-demi }\end{array}$ \\
\hline 219. & $240^{\mathrm{b}}$ & $\begin{array}{l}\text { Gel berüu bil ādem iseñ Ādem'i } \\
\text { Bilmeyen ādemler olmaz ādemī } \\
\text { Dünye vü 'ukbbāda bulmışdur necāt } \\
\text { Her ki bildi Ādem-ile Ḩātem'i }{ }^{445}\end{array}$ \\
\hline
\end{tabular}

\footnotetext{
${ }_{444} 214 / 3$ "cāmın" yazmada "cāmuñ" şeklinde "nazal n" ile yazılmıştır. Ancak "nun ile" yazılması gerektiğinden düzeltilmiştir.

${ }^{445}$ 219/2 Bilmeyen ādemler olmaz Ādemi: Bilmeyenler ādem olmaz Ādemi; 219/4 ādem-ile huātemi: ādem-ile Ādemi; ŞR
} 


\begin{tabular}{|c|c|c|}
\hline 220 & $240^{\mathrm{b}}$ & $\begin{array}{l}\text { Oldur ādem kim ura Hạk'dan demi } \\
\text { Ḥaḳ durur Ḥaḱ'dan dem ursa ādemi } \\
\text { Zahma ger urmaḳ dilerseñ merhemi } \\
\text { Sen de bulġıl on sekiz biñ 'ālemi }{ }^{446}\end{array}$ \\
\hline 221. & $240^{\mathrm{b}}$ & $\begin{array}{l}\text { Zülf-i 'anber-būya virdüm göñlümi } \\
\text { Misk-i Çīn gīsūya virdüm göñlümi } \\
\text { Mazhhar-1 Ḥak-rūya virdüm göñlümi } \\
\text { Ṣanma sen kim șuya virdüm göñlümi }\end{array}$ \\
\hline 222. & $240^{\mathrm{b}}$ & 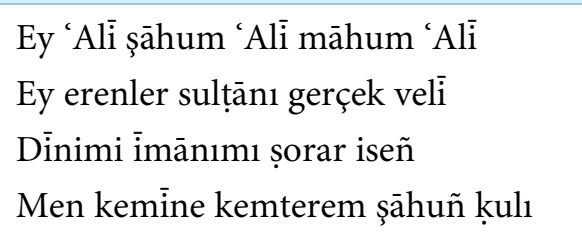 \\
\hline 223. & $241^{\mathrm{a}}$ & $\begin{array}{l}\text { Raḥmet añadur ki bilür ḳadrini } \\
\text { ‘İzzetin țatın yetürmez țavrını } \\
\text { Her kimüñlen 'ahd ider eyler vefā } \\
\text { Yüz çevirmez çekse biñ kez cevrini }\end{array}$ \\
\hline 224 & $241^{\mathrm{a}}$ & $\begin{array}{l}\text { Zülfüñ ne 'aceb kemend imiş hey } \\
\text { Șaçuñ girihi ne bend imiş hey } \\
\text { Ṣordum lebüñ ol nebāt aġzuñ } \\
\text { Şol şekker[i] çoḳ ne ḳand imiş hey }{ }^{447}\end{array}$ \\
\hline 225. & $241^{\mathrm{a}}$ & $\begin{array}{l}\text { Ey șabā behr-i Ḩudā ol yāre di } \\
\text { ‘Āşı̣uñ derdi ne bir kez yāre di } \\
\text { ‘Arża ḳıl hāälümi ol dildāre di } \\
\text { Senden ayru bu yüzüñ șad pāre di }\end{array}$ \\
\hline
\end{tabular}

Temmet Dīvân-1 Ḥażret-i Seyyid Nesimī ḳuddise sırruhu ${ }^{448}$

\footnotetext{
${ }_{446}^{233 / 1}$ Oldur ādem kim ura Ḥaḳ'dan demi: Oldur ādem k’ura Hạạ'dan ol demi; ŞR.

${ }^{447}$ mefûlü mefâilün fê̂ülü

448 İbarede Nesîmî Dîvânı'nın tamamlandığ 1 yazılsa da $241^{\mathrm{b}}-292^{\mathrm{b}}$ varakları arasında tuyuğ dışındaki nazım şekilleriyle (gazel, muhammes, tercî-bend vs.) yazılmış şiirler bulunmaktadır.
} 